USCS Research on Mineral Resources-1985

\title{
Program and Abstracts
}

V.E. McKelvey Forum

on Mineral and Energy Resources

LBREDS COPU

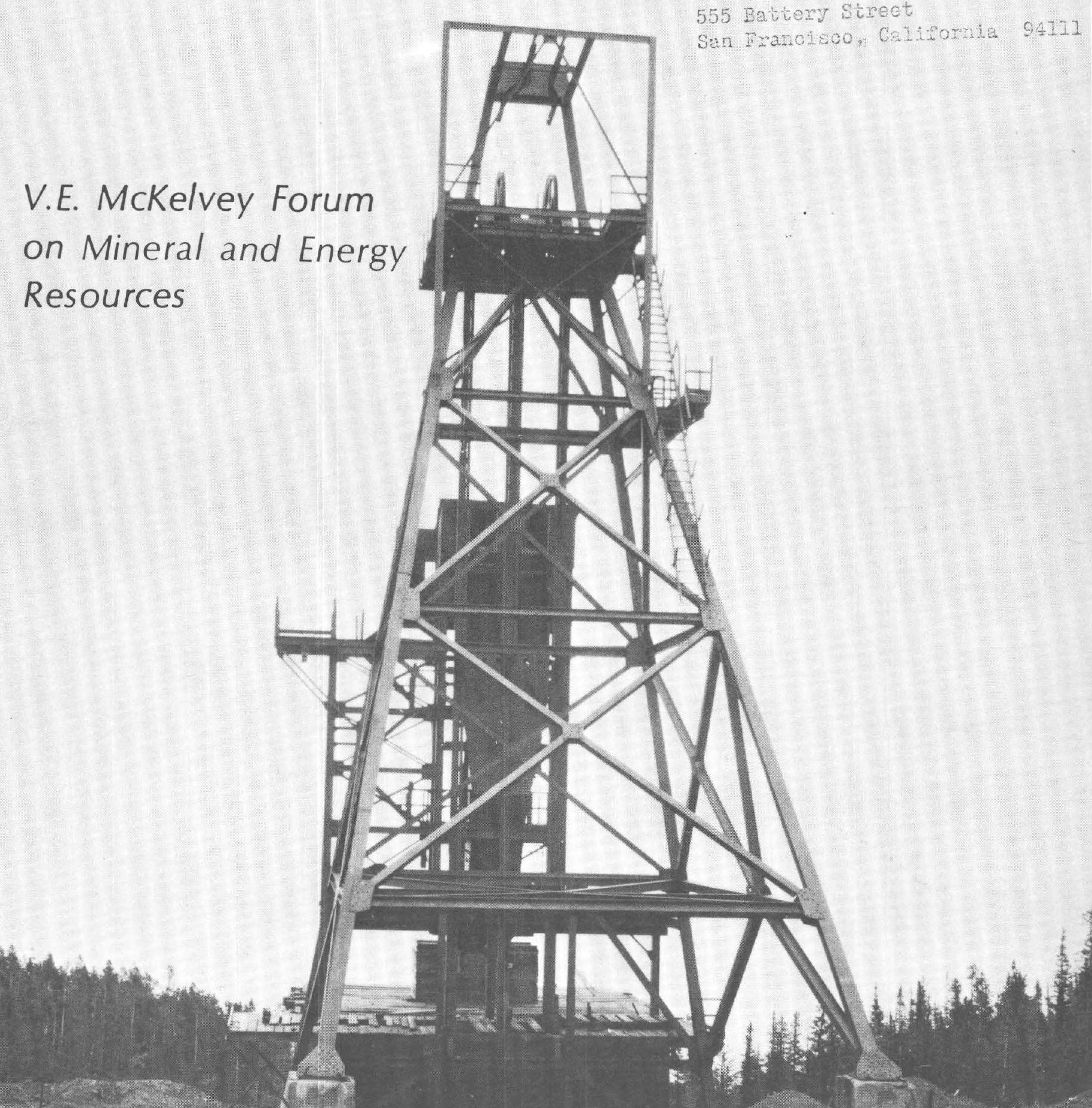

Public Inquiries Office

U.S. Geological Survey

504 Custon House

555 Battery Strect

San Francisco, Califormia

. 



\section{USCS Research on Mineral Resources-1985 Program and Abstracts}

Edited by Kathleen Krafft

V.E. McKelvey Forum on Mineral and Energy Resources

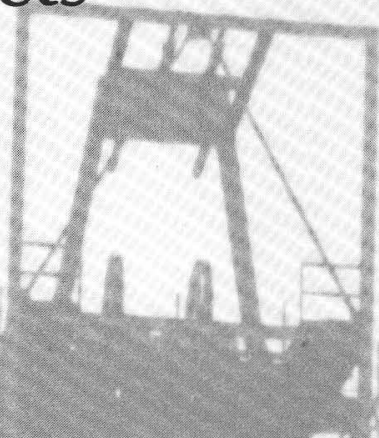




\section{Department of the Interior}

\section{WILLIAM P. CLARK, Secretary}

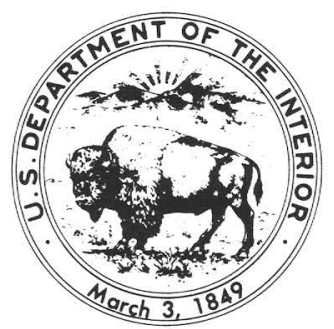

\section{U.S. Geological Survey}

Dallas L. Peck, Director

Organizing Committee for the 1985 McKelvey Forum:

Philip M. Bethke, Chairman

Charles G. Cunningham

Susan Hoffman

Kathleen Krafft

Gary P. Landis

Bruce R. Lipin

William R. Miller

Free on application to Distribution Branch, Text Products Section,

U. S. Geological Survey, 604 South Pickett Street, Alexandria, VA 22304 


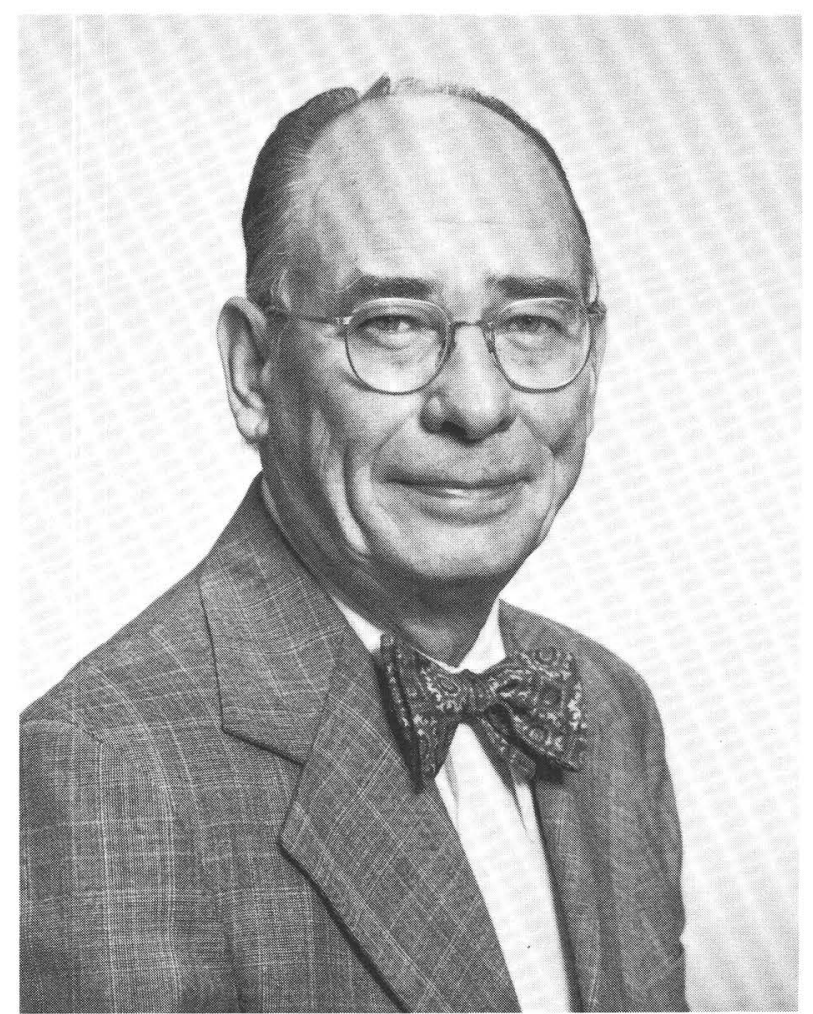

A society's wealth depends on the use it makes of raw materials, energy, and especially ingenuity

-V. E. McKelvey 


\section{FOREWORD}

\section{Dallas L. Peck, Director, U.S. Geological Survey}

The extended abstracts in this volume are summaries of the papers presented orally and as posters in the first V.E. McKelvey Forum on Mineral and Energy Resources, entitled "USGS Research on Mineral Resources-1985." The Forum has been established to improve communication between the USGS and the earth science community by presenting the results of current USGS research on nonrenewable resources in a timely fashion and by providing an opportunity for individuals from other organizations to meet informally with USGS scientists and managers. It is our hope that the McKelvey Forum will help to make USGS programs more responsive to the needs of the earth science community, particularly the mining and petroleum industries, and will foster closer cooperation between organizations and individuals.

The Forum was named after former Director Vincent E. McKelvey in recognition of his lifelong contributions to research, development, and administration in mineral and energy resources, as a scientist, as Chief Geologist, and as Director of the U.S. Geological Survey. The Forum will be an annual event, and its subject matter will alternate between mineral and energy resources. We expect that the format will change somewhat from year to year as various approaches are tried, but its primary purpose will remain the same: to encourage direct communication between USGS scientists and the representatives of other earth-science related organizations.

The topics selected for presentation at the first McKelvey Forum represent an overview of the scientific breadth of USGS research on mineral resources. They include the role of organic matter in forming and prospecting for ore deposits, the accumulation of metals in sedimentary basins, the evolution of oreforming hydrothermal fluids, and the concentration of sulfides and platinumgroup elements in ultramafic complexes. Research on methods of resource assessment using new geochemical and geophysical technology is described, along with studies devoted to the development and application of occurrence and genetic models of ore deposits. In addition to the technical sessions presenting the results of USGS research, each Congressionally mandated USGS Mineral Resource Program has a display outlining plans and progress.

We are all excited about this new opportunity to disseminate and discuss our research with our colleagues in industry and academia, and we welcome your suggestions on improving this new series of Forums.

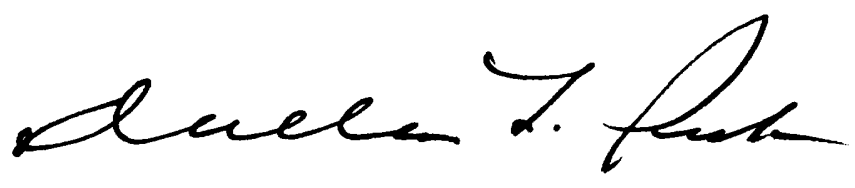




\section{PROGRAM}

Wednesday, February 6, 1985

8:15 a.m. -Session I (Grand Ballroom)

Thomas P. Miller and Charles H. Thorman presiding

Opening remarks . . . . Robert $M$. Hamilton

Introduction to Mineral Resource Studies .Glenn H. Allcott

Metallogeny of Archean and Proterozoic terranes in the Lake Superior region. . . . . . . P.K. Sims

Metallogenetic history of the Wrangellia terrane, eastern Alaska Range, Alaska. . . . . . Warren J. Nokleberg and Ian M. Lange

Mineral deposit models-Theory and practice.... Steve Ludington and Paul Barton

10:00 a.m. -Coffee break (Piccadilly Lane)

10:30 a.m. -Session I continued (Grand Ballroom)

Chemistry of ore-forming fluids . . . . . . . Robert J. Bodnar, I-Ming Chou, and Edwin Roedder

Spectra of massive sulfide gossan and false gossan in the near infrared $(800 \mathrm{~nm}$ to $2500 \mathrm{~nm})$. . . . . Gary L. Raines, Linda G. McGee, and Steven J. Sutley

Preliminary results of an ALVIN dive program on active hydrothermal vents at the southern Juan de Fuca ridge. . . . . . USGS Juan de Fuca Study Group

12:00 noon -Luncheon honoring Vincent E. McKelvey (Grand Salon)

Keynote speaker Dallas L. Peck

"Mineral Resources Research: Opportunities for Government-Industry Cooperation"

2:00 p.m. -Session II (Grand Ballroom)

Frank C. Frischknecht and Edwin $H$. McKee presiding

Metal concentrations in marine black shales. . . . . . . . . Forrest G. Poole and George A. Desborough

Sediment-hosted ore deposits: Genetic processes inferred from the mineralogic, chemical, and isotopic composition of clay minerals. . . . . . . . H. Roy Northrop and Gene Whitney

Stratigraphic and structural controls of Mississippi Valley-type ore deposits in Tennessee.........Joseph A. Briskey, Augustus K. Armstrong, Paul R. Dingess, Ray C. Gilbert, Walt B. Gaylord, and George P. Cole

3:30 p.m. -Coffee break (Piccadilly Lane)
4:00 p.m. -Session II continued (Grand Ballroom)

Origin of sedimentary humic acids, potential carriers of ore-forming elements. . . . . . . Patrick G. Hatcher

Recent studies of the distribution of Bacillus cereus near subsurface gold deposits.... . Nancy L. Parduhn, John R. Watterson, and Miles L. Silberman

A strategy in the exploration for sedimentary manganese ores. . . . . . William $F$. Cannon and Eric $R$. Force

5:30-6:30 p.m. - Mixer (Grand Salon)

8:00-10:30 p.m. - Keg and poster session (Piccadilly Lane and Rotunda)

Thursday, February 7, 1985

8:30 a.m. -Session III (Grand Ballroom)

Lawrence J. Drew and Bruce R. Lipin presiding

Tin, molybdenum, and other metal elements in silicic magmas and their relation to fluorine and chlorine distribution. . . . . . Robert L. Smith

Heat transfer and brine evolution in magmahydrothermal systems.......Robert $O$. Fournier

Multiple episodes of mineralization in the southern Toquima Range, Nye County, Nevada. . . . . . . . . Daniel R. Shawe

10:00 a.m. -Coffee break (Piccadilly Lane)

10:30 a.m. -Session III continued

Development of disseminated gold deposits of Cortez, Horse Canyon, and Gold Acres, Nevada, at the end stage of caldera-related volcanism. . . . . . . . James J. Rytuba

Aeromagnetic and radiometric signatures of a possible porphyry system in the western Tushar Mountains, Utah . . . . . . . David L. Campbell, James A. Pitkin, Joseph S. Duval, Thomas A. Steven, Charles $G$. Cunningham, and C.W. Naeser

Fission-track dating applied to mineral exploration.......C.W. Naeser and Charles G. Cunningham

Episodic metallization in the western San Juan caldera complex, Colorado. . . . . . . . R.I. Grauch, Ken Hon, R.L. Reynolds, D.J. Bove, and V.J.S. Grauch

2:00-4:00 p.m. - Poster session (Rotunda) and

Open house at U.S. Geological Survey laboratories, Branches of Analytical Chemistry and Exploration Geochemistry 


\section{POSTER SESSIONS}

Mineral Resource Programs

Strategic and Critical Minerals program........Alfred $H$. Chidester

The Development of Assessment Techniques program. . . Charles $G$. Cunningham

The Alaska Mineral Resources Assessment Program.... . Gary R. Winkler

The Conterminous United States Mineral Assessment Pro gram........................ Gary C. Curtin

Mineral Resources of Public Lands.... . Gus H. Goudarzi and Susan M. Marcus

Availability and application of NURE data sets in regional mineral survey programs of the U.S. Geological Survey . . Byron R. Berger, Thomas D. Fouch, Richard H. Godson, and Bruce F. Molnia

The U.S. Geological Survey EEZ program. Terry W. Offield

Uranium and thorium investigations in the U.S. Geological Survey . . . . . . Thomas D. Fouch and Jennie L. Ridgley

Federal Mineral Land Information System....... Richard L. Kleckner

\section{Geophysical Exploration Techniques}

Geophysical exploration for breccia pipes on the Colorado Plateau of northern Arizona . . . . Vincent J. Flanigan and Carl L. Long

A comparison of Landsat Thematic Mapper, Multispectral Scanner, and airborne sensors for mapping the distribution of alteration minerals: examples from the Southwestern United States. . . . . . . M.H. Podwysocki, M.S. Power, O.D. Jones, M.H. Koslow, and William E. Collins 11

Processing of Landsat imagery to map surface mineral alteration on the Alaska Peninsula, Alaska. . . . Frederic H. Wilson and James E. York

Electrical geophysical studies of massive sulfide deposits and their host rocks, West Shasta copper-zinc district. . Robert Horton and Bruce D. Smith

Aeromagnetic and gravity models of the pluton below the Lake City caldera, Colorado. . . . . . . . . . . V.J.S. Grauch

Some geophysical guides to ore in southern and southwestern Alaska. J.E. Case

\section{Other Exploration Methods}

Research on kimberlites and applications to diamond prospecting . . . . . B. Carter Hearn, Jr., and Elaine S. McGee

Volatile elements and compounds in exploration geochemistry . . . . Margaret E. Hinkle and J. Howard McCarthy

Partial chemical extractions-Their application to geochemical exploration for ore deposits in the tropical environment Robert E. Learned, T.T. Chao, and Richard F. Sanzolone

Metals in plants-Exploration of the Red Mountain goldbearing stockwork, Yellow Pine district, Idaho . . . . B.F. Leonard, J.A. Erdman, and D.M. McKown

Microbiology of soil derived from a copper deposit. . . . . . . John R. Watterson. Sarah S. Elliott, Nancy L. Parduhn, and David $M$. Updegraff

Mooth Minerals in the Oceans

Booth

Organic matter associated with metal ores of hydrothermal vent origin . . . William H. Orem, Patrick G. Hatcher, and Elliott C. Spiker

2 Geologic and hydrothermal characteristics of the Gorda Ridge. . . . . . . . . David A. Clague and Mark Holmes 22

3 Cobalt-rich ferromanganese crusts in the oceans........ James R. Hein and Frank T. Manheim

4 Genesis of metalliferous sediment in the Atlantis II Deep. Red Sea Robert A. Zierenberg

5 Economic heavy minerals of the U.S. Atlantic Continental Shelf. . . . . . . Andrew E. Grosz, Edward C. Escowitz, S. Jeffress Williams, Ricardo Lopez, John C. Hathaway, Joseph M. Botbol, and Laurence J. Poppe

6 Massive sulfide deposits from the southern Juan de Fuca Ridge. . . . . . . . Randolph A. Koski, David A. Clague, James L. Bischoff, and Robert A. Zierenberg

9 Regional Syntheses

Early and middle Cenozoic volcanic syntheses. . . . Robert G. Luedke

Sediment dispersal pattern in the emerged Atlantic Coastal Plain (New Jersey-Georgia) from Early Cretaceous to Holocene: A guide to placer deposits

James P. Owens

Marine phosphorite deposits model for exploration, with emphasis on the deposits in the Atlantic Coastal Plain of the United States. . . . . . . . . . . James B. Cathcart

New silver resource map of the United States-Potential for increased domestic silver production . . . . . . Allen $V$. Heyl and Robert B. Hall

Geology and geochemistry of wall rocks of Appalachian massive sulfide deposits . . . . . . . . . . . Jacob E. Gair

Base metals, precious metals, and molybdenum: New occurrence types in the Western United States.... . Wayne Hall, Steve Ludington, Ted G. Theodore, and Norman J Page

Identification of regional mineral resource targets by using ore deposit models-Two examples from the Eastern U.S. early Mesozoic basins . . . . Gilpin R. Robinson, Jr., and David Gottfried

Some recent deposit modeling efforts . . . . . . D.A. Singer and D.P. Cox 
Pathfinder elements in soils over the Dee disseminated gold deposit, Elko County, Nevada . . . . . . W.C. Bagby, W.J. Pickthorm, and R.J. Goldfarb

Characteristics of lode-gold deposits in the Prince William Sound region, southern Alaska . . . . . . . . . Miles $L$. Silberman and Dawn J. Madden

Mahd adh Dhahab, a Proterozoic epithermal preciousmetal deposit, Kingdom of Saudi Arabia. . . . . . . R.G. Worl and J.L. Doebrich

\section{Igneous-Hosted Deposits}

Volcanic and hydrothermal systems: Early Proterozoic massive sulfide deposits, Bagdad, Arizona. ...... Clay M. Conway, Thomas J. Connelly, and Lori C. Robison

The setting and distribution of copper-nickel sulfides in the South Kawishiwi intrusion, Duluth Complex, Minnesota.......................Michael P. Foose

Studies of ore deposits in the early magmatic environment: The Stillwater Complex, Montana . . . . . Norman J Page, W.J. Bawiec, R.J. Blakely, G.K. Czamanske, L.J. Drew, Michael P. Foose, R.L. Helz, M.D. Kleinkopf, Bruce R. Lipin, Patricia J. Loferski, J.H. Schuenemeyer, and M.L. Zientek

High-alumina hydrothermal alteration systems and their role in mineral exploration, Southeastern United States. . . . . . . . . . . . R.G. Schmidt and T.L. Klein 4

Characteristics of and exploration for $\mathrm{Sn}-\mathrm{W}$ granites in the Precambrian Arabian Shield. . Edward A. du Bray
Gas analysis of ore-forming fluids G.P. Landis

Precious and base metal mineralization in the Coeur d'Alene district, Idaho, during Proterozoic metamorphism of the Belt basin . . . . . . . . . . David L. Leach, G.P. Landis, and Albert H. Hofstra

Thermodynamic properties of minerals.........Richard A. Robie, Bruce S. Hemingway, and John L. Haas, Jr.

Resource Assessments: Techniques and Case Histories

The role of regional subsurface geochemistry in resource assessment in the Central United States . . . . . . . R.L. Erickson, E.L. Mosier, J.G. Viets, and M.S. Erickson

Mineral resource assessment of the San Isabel National Forest, Colorado: A prototype for 1:250,000-scale multidisciplinary assessments "from the literature" . . . . . . . Richard B. Taylor and John S. Dersch

Mineral resources of the Survey Pass quadrangle, Brooks Range, Alaska. . . . . . . . Donald J. Grybeck and Steven W. Nelson

A multidisciplinary resource assessment of the Chugach National Forest, Alaska. . . . . . . . . Steven W. Nelson 51 Applications of the Mineral Resources Data System and the International Strategic Minerals Inventory in mineral-resource assessments by region and commodity . . . . . . . . Antoinette L. Medlin, David M. Sutphin, and John H. DeYoung, Jr.

Expert systems research in regional resource evaluation: Experiences in the application of microcomputer technologies Richard B. McCammon 6 7 
This Circular uses the following abbreviations:

EEZ-Exclusive Economic Zone

$\mathrm{Ga}$-giga-annum $\left(10^{9}\right.$ years ago)

$\mathrm{Ma}-$ mega-annum $\left(10^{6}\right.$ years ago $)$

m.y. $-10^{6}$ years duration

REE-rare-earth element

The Deep Submergence Research Vehicle ALVIN is referred to throughout as ALVIN. 


\title{
V.E. McKelvey Forum on Mineral and Energy Resources \\ USGS Research on Mineral Resources-1985 Program and Abstracts
}

\author{
Edited by Kathleen Krafft
}

\section{PATHFINDER ELEMENTS IN SOILS OVER THE DEE DISSEMINATED GOLD DEPOSIT, ELKO COUNTY, NEVADA}

\section{W.C. Bagby, W.J. Pickthorn, and R.J. Goldfarb}

The Dee disseminated gold deposit, owned and operated by Cordex Syndicate in Elko County, Nevada, is the northernmost mine in the Carlin gold belt. Soil samples were collected from undisturbed areas overlying the deposit to determine the usefulness of soil geochemistry in identifying separate ore zones. Samples were collected at random sites within a grid. The depth of sampling ranged from 30 to 35 centimeters, depending on soil depth. Each sample was double-bagged, in plastic and cloth, to prevent cross contamination, and was sieved in the laboratory. The -80 mesh fraction was analyzed by atomic absorption for $\mathrm{Au}, \mathrm{As}, \mathrm{Sb}, \mathrm{Hg}$, and $\mathrm{Tl}$ and by semiquantitative spectrographic analysis for Ag. Correlations on log-transformed data for the complete sample population are very low. Subpopulations within the whole set, however, have improved correlations. These subpopulations were identified by plotting the samples on histograms and using the obvious histogram breaks to separate the elements into concentration ranges. As a first approximation, samples with values falling in the two highest histogram groups were considered to be anomalous for the sample population.

The three anomalous areas thus identified were compared with the surface projections of ore zones already drilled and defined by Cordex: (1) a large area of multielement ( $\mathrm{Au}, \mathrm{As}, \mathrm{Sb}, \mathrm{Hg}, \mathrm{Tl}$, and $\mathrm{Ag}$ ) anomalous samples covering parts of all known ore zones, (2) a small area defined by anomalous $\mathrm{Hg}$, and (3) a small area defined by anomalous $\mathrm{Tl}$. Samples containing anomalous $\mathrm{Hg}$ lie approximately 60 meters directly above ore, whereas samples containing anomalous $\mathrm{Tl}$ are offset approximately 15 meters to the side of known ore.

High-potential targets within the multielement anomalous area were defined by outlining three or more anomalous samples that contain element concentrations in the uppermost histogram group for any given element and were spatially associated within an area of $5,806 \mathrm{~m}^{2}$ or less, as defined by a north-south grid. This resulted in four additional, more tightly defined, anomalous zones: an area defined by $\mathrm{Au}$ and $\mathrm{Hg}$, another defined by $\mathrm{Ag}$ and $\mathrm{Sb}$, and two areas defined only by As. The $\mathrm{Au}-\mathrm{Hg}$, the Ag-Sb, and one of the As anomalies all occur above known ore zones; the second highpotential As area is adjacent to ore.

\section{CHEMISTRY OF ORE-FORMING FLUIDS}

\section{Robert J. Bodnar, ${ }^{1}$ I-Ming Chou, and Edwin Roedder}

Highly saline brines of various compositions have been involved in the formation of many types of ore deposit and have been trapped in fluid inclusions in the minerals of these deposits. Study of the phase relations of such fluid inclusions, which may contain many daughter crystals formed during cooling, can provide semiquantitative and in part quantitative data on their composition. Knowledge of the chemistry of such fluids is essential to understanding the processes involved in ore transport and deposition. However, the interpretation of fluid-inclusion data is hindered by the lack of data on salt solubilities and on volumetric properties of brines at elevated $P$ and $T$.

${ }^{1}$ R.J. Bodnar, Chevron Oil Field Research Company, P.O. Box 446, La Habra, CA 90631. 


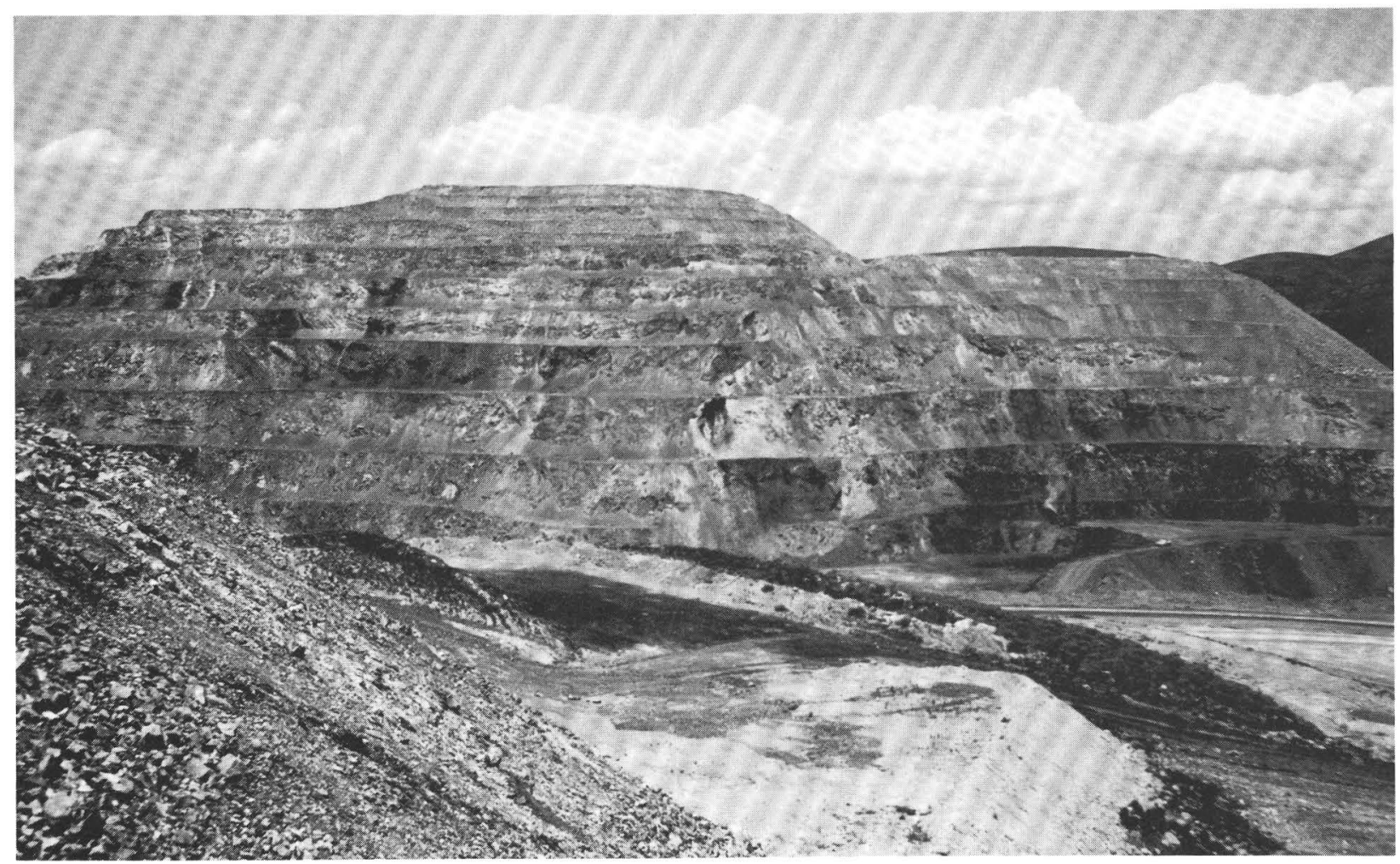

North wall of the Old Main and East pit, Carlin gold mine, Nevada

Phase equilibria in the $\mathrm{H}_{2} \mathrm{O}-\mathrm{NaCl}$ system have been determined experimentally to $1000^{\circ} \mathrm{C}$ and 1500 bars by studying synthetic fluid inclusions in natural quartz. The results indicate a much larger immiscibility field for $\mathrm{H}_{2} \mathrm{O}-\mathrm{NaCl}$ than had been previously proposed. Solubility relations in the system $\mathrm{NaCl}-\mathrm{KCl}-\mathrm{H}_{2} \mathrm{O}$ have been determined by differential thermal analysis for compositions having more than 53 weight percent total salt, at pressures and temperatures up to $2 \mathrm{kbar}$ and $820^{\circ} \mathrm{C}$.

Volumetric $(P V T X)$ properties of $\mathrm{H}_{2} \mathrm{O}-\mathrm{NaCl}$ compositions of 30,50 , and 70 weight percent $\mathrm{NaCl}$ have been determined experimentally over the range $20-900^{\circ} \mathrm{C}$ and $0.5-5 \mathrm{kbar}$. These results have been combined with other available volumetric data for $\mathrm{H}_{2} \mathrm{O}-\mathrm{NaCl}$ to generate a single equation for specific volume as a function of temperature, pressure, and composition. This equation, which has the form

$$
V=\mathrm{e}^{\sum_{i=0}^{3} \sum_{j=0}^{3} \sum_{k=0}^{3} \mathrm{a}^{\mathrm{a}_{i j k}\left(T^{i} P^{j} X^{k}\right)}}
$$

provides a reasonable approximation of specific volumes of $\mathrm{H}_{2} \mathrm{O}-\mathrm{NaCl}$ mixtures over the range $100-900^{\circ} \mathrm{C}, 0.5-5 \mathrm{kbar}$, and $0-100$ weight percent $\mathrm{NaCl}$ and is valid in both the one-phase (fluid) and two-phase (fluid+solid) fields. Using a similar equation, with metastable liquid $\mathrm{NaCl}$ as the standard state, we have calculated partial molar volumes of both the $\mathrm{H}_{2} \mathrm{O}$ and $\mathrm{NaCl}$ components in $\mathrm{H}_{2} \mathrm{O}-\mathrm{NaCl}$ solutions over the same $P T X$ range.

Careful petrography permits recognition of some inclusions as samples of pre-ore or post-ore fluids responsible for wallrock alteration, whereas others can be shown to be samples of the actual ore-forming fluid. Studies now in progress include identifying and validating the criteria for determining inclusion origin and examining various procedures for obtaining compositional data on inclusions. A study of the brines present during the formation and later diagenesis of salt beds provides a low-temperature example. Compositional data on these brine inclusions have been obtained by two main procedures: (1) microscopy plus microthermometry of daughter crystal dissolution and (2) extraction and chemical analysis of single 
1-mm inclusions for $\mathrm{Na}, \mathrm{K}, \mathrm{Ca}, \mathrm{Mg}, \mathrm{Cl}, \mathrm{SO}_{4}$, and $\mathrm{Br}$. Although the purpose is to evaluate the salt beds for possible nuclear waste repository sites, the work has helped in the study of similar highly saline brine inclusions from metallic ore deposits and has provided a possible tool for the search for potash ore deposits.

\section{STRATIGRAPHIC AND STRUCTURAL CONTROLS OF MISSISSIPPI VALLEY-TYPE ORE DEPOSITS IN TENNESSEE}

\section{Joseph A. Briskey, Augustus K. Armstrong,}

Paul R. Dingess, ${ }^{2}$ Ray C. Gilbert, ${ }^{3}$ Walt B. Gaylord, ${ }^{4}$ and George P. Cole

Mississippi Valley-type deposits of sphalerite ( \pm galena, barite, and fluorite) in carbonate rocks of the Cambrian-Ordovician Knox Group in east and central Tennessee are the principal domestic sources of zinc, supplying 40 percent of U.S. production. Discovery of new ore bodies or districts, which now is dependent on nearly random drilling of large areas underlain at relatively shallow depth by favorable host rock, would be enhanced if the geologic controls of this type of deposit were better understood. Cooperative work recently begun by the USGS, the mining industry, and the Division of Geology of the Tennessee Department of Conservation is designed to improve understanding of the genesis and localization of these deposits. The principal goals include identifying and documenting (1) the geologic and geochemical controls of ore deposition, with which this abstract is chiefly concerned, (2) the channelways that guided mineralizing fluids to sites of ore deposition, and (3) the rocks that were the source of fluids, metals, sulfur, and hydrocarbons to form the deposits.

Mineralization occurred principally by filling of caverns and of open spaces in dissolution collapse breccias, both of which formed in paleoaquifers related to paleokarst development on and below the regional unconformity at the top of the Knox Group. These breccias formed as a result of

${ }^{2}$ Paul R. Dingess, Asarco Exploration, P.O. Box 306, Salem, MO 65560 .

${ }^{3}$ Ray C. Gilbert, Tennessee Department of Geology, 701 Broadway, Nashville, TN 37203.

${ }^{4}$ Walt B. Gaylord, Jersey Miniere Zinc Company, P.O. Box 249, Gordonsville, TN 38563.

${ }^{5}$ George P. Cole, Cominco American Inc., 831 East Glendale, Sparks, NV 89431 dissolution of soluble limestone, followed by collapse of overlying, relatively insoluble dolostone beds. Consequently, the breccias are most common along limestone-dolostone facies contacts.

In contrast to deposits in the paleokarst environment, some large zinc deposits in central Tennessee were localized by "primary" carbonate rock porosity. These deposits are in detrital carbonate rocks formed in tidal channels betweer stromatolites and stromatolite biostromes that also are locally mineralized. Stromatolites forming today in Shark Bay, Australia, appear to be modern analogues of those in the Knox Group in central Tennessee.

Broad, gently dipping $\left(2-5^{\circ}\right)$ structural highs control the distribution of ore within porous and permeable stratigraphic horizons in central Tennessee. Ore bodies are confined to the flanks and crests of these highs. This relationship may reflect the accumulation of hydrocarbons in the structural highs. Introduction of metalliferous brines containing sulfate from carbonate host rocks into the hydrocarbon-rich area would have resulted in the reduction of sulfate to sulfide and consequent precipitation of base-metal sulfides.

The importance of stratigraphic and structural features in the localization of the Tennessee deposits emphasizes the need for detailed geologic analysis of potential host rocks, both before and during exploration drilling. Predicting the occurrence and distribution of porous and permeable zones, and of structural and stratigraphic traps, would provide specific drilling targets, thereby reducing the large number of holes now required by random exploratory drilling. Obvious benefits include both decreased drilling costs and increased rates of discovery of ore.

\section{AEROMAGNETIC AND RADIOMETRIC SIGNATURES OF A POSSIBLE PORPHYRY SYSTEM IN THE WESTERN TUSHAR MOUNTAINS, UTAH}

\section{David L. Campbell, James A. Pitkin, Joseph S. Duval, Thomas A. Steven, Charles G. Cunningham, and C.W. Naeser}

Geologic mapping, petrologic analysis, isotopic dating, geochemical sampling, and geophysical studies have identified several areas in the western Tushar Mountains, Utah, that may be underlain by mineralized intrusive systems containing molybdenum, uranium, and other valuable 


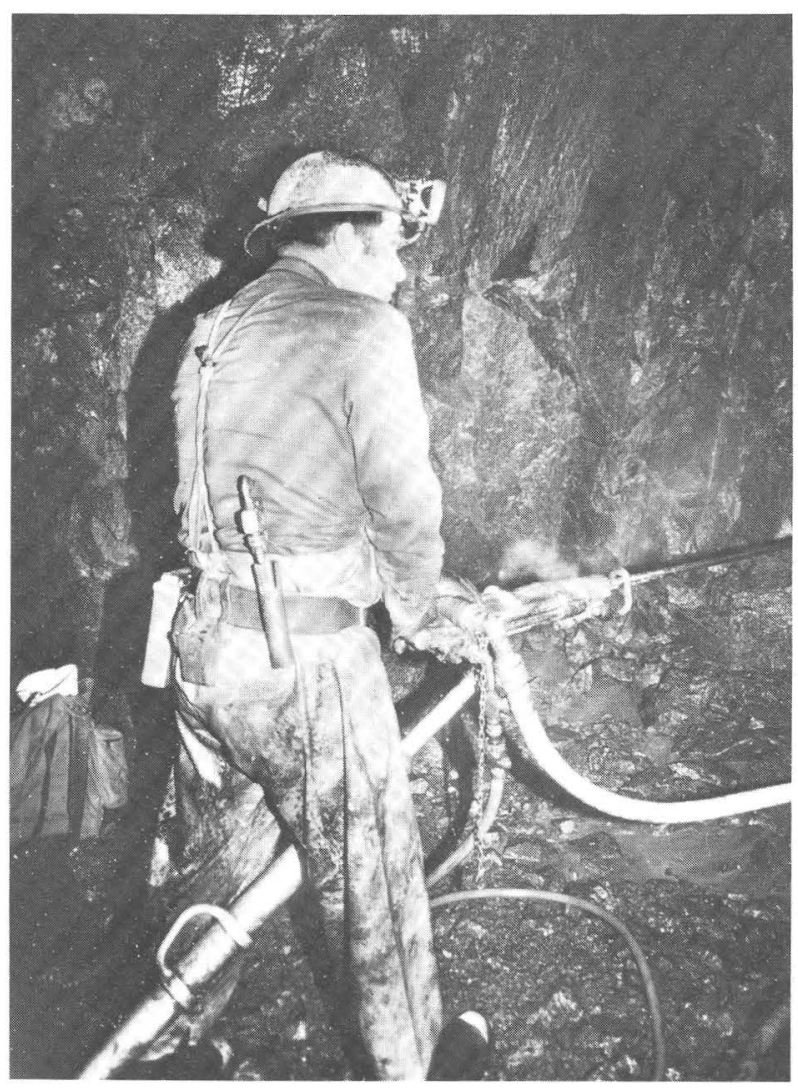

Hard-rock uranium mining, Marysvale, Utah

metals. One of these areas is near Indian Creek, $18 \mathrm{~km}$ north of Beaver, Utah, where there may be a multiply intruded mineralized stock. Several lines of evidence were pulled together to make this interpretation, providing a good example of synergism in geological research. This report focuses on the geophysical component of these studies.

The Indian Creek area is characterized on the aeromagnetic map by a horseshoe-shaped anomaly, a strong magnetic high with a reentrant central low. The high rim of this distinctive signature may be caused by the relatively magnetic 23-Ma Indian Creek granodiorite. The central low part of the anomaly lies over a number of $16-\mathrm{Ma}$ rhyolite dikes, which probably are near-surface manifestations of a low-susceptibility pluton at depth. Alteration related to this hidden intrusion also may have destroyed earlier magnetic minerals and thus have contributed to the magnetic low. Horseshoe- or doughnut-shaped magnetic anomalies can be caused by a variety of geological circumstances, but where geological and geochemical lines of evidence point to a porphyry system, such a signature shape can pinpoint the locus of most intense alteration and thus the core of the possible exploration target.

Spectral radiometric surveys over the Indian Creek area showed relatively high concentrations of potassium $(\mathrm{K})$, equivalent uranium $(\mathrm{eU})$, and equivalent thorium (eTh). The $\mathrm{K}$ and $\mathrm{U}$ were probably introduced during hydrothermal alteration. The three spectral radiometric signatures were combined in a color radiometric composite (CRC) map, an image in which the abundance of $\mathrm{K}$ is represented by the intensity of blue, eU by red, and eTh by yellow. The changing tints on a CRC map thereby show $\mathrm{K}$, eU, and eTh geochemical variations at a glance. Many of the tints on the CRC map were immediately correlatable with known geology, and the proposed porphyry system at Indian Creek was unmistakable. In addition, the CRC map highlighted other nearby areas showing high concentrations of radioelements and so may point to other possible porphyry systems.

\section{A STRATEGY IN THE EXPLORATION FOR SEDIMENTARY MANGANESE ORES}

\section{William F. Cannon and Eric R. Force}

Sedimentary manganese ores consist of primary accumulations of manganese oxides, carbonates, and silicates deposited in relatively shallow marine water. Examples include giant deposits such as the Kalahari Field (lower Proterozoic) of South Africa, the Molango district (Jurassic) of Mexico, and the Nikopol and Chiatura districts (Oligocene) of the U.S.S.R.

Exploration for such deposits should be restricted to areas containing rocks that (1) were deposited in extensive shelf or platform seas, (2) are time equivalents to rocks of euxinic facies elsewhere in the basin, (3) were deposited near paleoislands or paleoshoals, (4) were deposited in areas of upwelling, and (5) were deposited during high eustatic sea level when global climate was warm. Criteria 1-4 can be used to identify favorable parts of basins and favorable stratigraphic units for detailed exploration. Criterion 5 helps to define favorable time windows in any basin.

The formation of manganese ore requires not only concentration of manganese to several hundred times its average crustal abundance but also 
fractionation of manganese from iron, with which it shares many geochemical properties. Ores best suited for metallurgical uses have $\mathrm{Mn}-\mathrm{Fe}$ ratios of 7 or greater whereas $\mathrm{Mn}: \mathrm{Fe}$ of about 0.2 is typical of most rocks. Euxinic basins are capable of producing such fractionation on the scale required to form large manganese deposits. In water, iron sulfide is stable over a considerable range of low Eh conditions, hence most iron is fixed in this solid form resulting in very low dissolved iron. No comparable stability range exists for manganese sulfides, so dissolved $\mathrm{Mn}^{2+}$ remains high. If such lowEh water is oxidized or raised to high $\mathrm{pH}$, it will crystallize manganese minerals in greater abundance than iron minerals and thus may become the ore fluid to form manganese deposits.

The identification of euxinic facies is, therefore, a key to searching for manganese. Rocks formed in truly euxinic conditions, as opposed to other organic-matter-rich environments, can be recognized by laminated organic-matter-rich pyritic shales with sulfur:organic carbon generally greater than 0.4. Because manganese is soluble in euxinic conditions, these black shales themselves are not likely host rocks and, in fact, should show manganese depletion relative to iron. Rather, manganese should accumulate in time-equivalent deposits in more oxygenated parts of the basin.

There is growing evidence that certain time intervals are most favorable for the generation of euxinic conditions. These are times of very high eustatic sea level, generally warm global climates, and consequent subdued oceanic circulation, which promotes stratification of oceans and development of euxinic conditions.

Another requirement to form ore is the transportation of dissolved manganese on a large scale from the euxinic into the oxidized part of the basin. Wind-driven currents and resultant upwelling are the likely mechanisms for this, so some understanding of paleoclimate and paleogeography is important. Known deposits worldwide show a tendency to occur near paleoislands or paleoshoals, probably because the shallow sea floor in these areas provided the required oxidized depositional and diagenetic setting without major clastic input. Comparably shallow conditions peripheral to larger land masses are likely to be dominated by clastic material delivered by major river systems. Also, shoals might provide physical barriers to lateral circulation and cause the upwelling and oxidation of deeper euxinic waters.
Finally, once favorable regions are identified using the above criteria, the search for deposits must depend on detailed chemical studies of lateral and stratigraphic distribution of manganese to identify enrichment trends that could lead to ore.

\section{SOME GEOPHYSICAL GUIDES TO ORE IN SOUTHERN AND SOUTHWESTERN ALASKA}

\section{J.E. Case}

In southern Alaska, massive sulfide deposits are associated with Late Cretaceous-Paleogene pillow basalt, sheeted dikes, and overlying flysch deposits. Most such mafic assemblages in Prince William Sound are characterized by prominent positive gravity anomalies. Magnetic anomalies over the volcanic belts are positive, but their amplitudes range widely. Where massive sulfide deposits occur on Knight Island and the Ellamar Peninsula, magnetic anomalies are relatively flat or negative-a strong indication of hydrothermal alteration accompanying mineralization. To the north and west, a belt of late Mesozoic gabbros, diorites, and ultramafic rocks of the northern Chugach Range and western Kenai Peninsula is indicated by large positive gravity and magnetic anomalies. These rocks may contain chromite, massive sulfide, magnetite, and gold deposits. The gravity and magnetic anomalies show that the complex continues beneath glaciers, alluvial cover, and water-covered areas.

On the Alaska Peninsula, ore deposits include porphyry copper-molybdenum types, some of which are accompanied by gold deposits. Few significant gravity anomalies have yet been identified, except that large granitoid plutons of Tertiary age commonly cause negative anomalies. Magnetic anomalies, however, have a twofold role in identifying granitoid plutons. First, most plutons cause prominent ovoid magnetic highs, which coincide with "centers of mineralization" as defined on the basis of geochemical anomalies and outcrop geology by D. Cox and D. Detra. Second, the most highly mineralized areas on or adjacent to the granitoid plutons are commonly expressed by subdued or relative negative anomalies, also indicating alteration associated with the ore-forming process.

Elsewhere in southern and southwestern Alas$\mathrm{ka}$, gold deposits in the flysch terrane west of the 


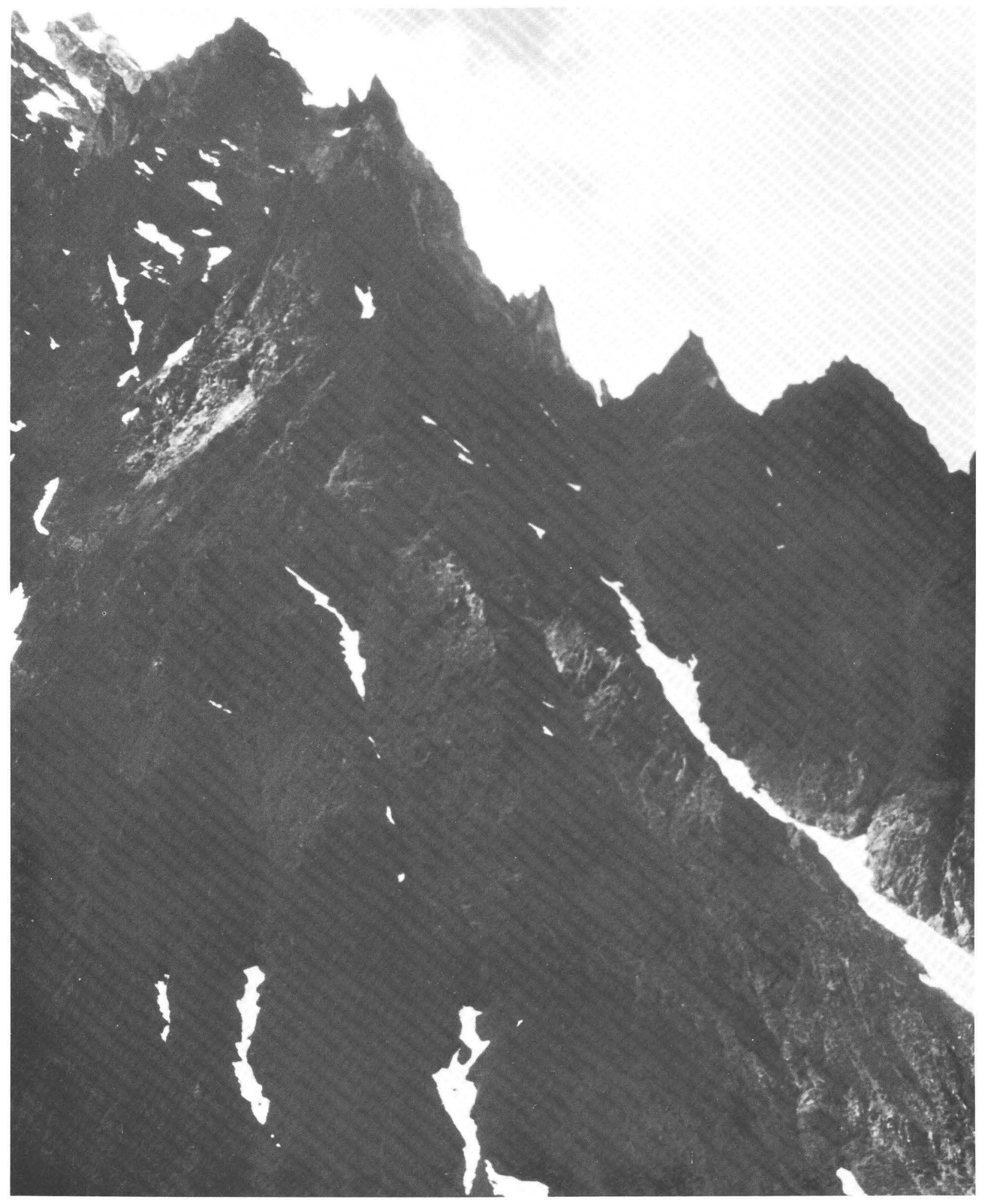

Rugged topography, Chugach Mountains, southern Alaska 
Alaska-Aleutian Range batholith are commonly associated directly or indirectly with granitoid plutons that cut the Mesozoic flysch. These plutons normally produce small-amplitude positive magnetic anomalies, or no anomaly at all, surrounded by negative anomalies caused by reversely magnetized pyrrhotite that resulted from metamorphism in contact aureoles.

Major positive magnetic anomalies on the Alaska Peninsula are produced by magnetite-rich sandstones of the Naknek Formation of Jurassic age whose sedimentary provenance is the AlaskaAleutian Range batholith of Jurassic age. Whether fossil placer gold deposits might be associated with the Naknek Formation remains to be determined by geochemical sampling.

\section{MARINE PHOSPHORITE DEPOSITS MODEL FOR EXPLORATION, WITH EMPHASIS ON DEPOSITS IN THE U.S. ATLANTIC COASTAL PLAIN}

\section{James B. Cathcart}

Phosphorus is an essential element for growth in plants and animals; its principal source is deposits of phosphate rock. Onshore deposits of phosphorite, a marine sedimentary rock, constitute about 80 percent of the world's phosphate resources and are the source for about 80 percent of world production. Identified resources (reserve base) of phosphorite in the world are estimated to be about 69 billion metric tons containing at least 25 percent $\mathrm{P}_{2} \mathrm{O}_{5}$, and resources in deposits that may become economic are thought to be about double the identified resources. Deposits on the sea floor form an additional, probably enormous, resource.

The origin of marine phosphorites is complex. The phosphate originates in sea water, which is less saturated with $\mathrm{P}_{2} \mathrm{O}_{5}$ at low temperature and high pressure. Therefore, warm surface water is saturated while cool, deep, or polar ocean water is undersaturated. Although some phosphate is being precipitated in sediments on the floor of the modern ocean, the large offshore deposits are either Miocene or Cretaceous in age.

Major deposits differ in detail, but the following common factors can be used to formulate a model for exploration.
(1) Size: Resources are hundreds of billions of metric tons; reserves are billions or tens of billions of metric tons.

(2) Periodicity: Major phosphogenic episodes are confined to four time periods: Late Proterozoic to Early Cambrian, Late Permian, Late Cretaceous to early Eocene, and Miocene.

(3) Paleogeography: Phosphate was deposited at low paleolatitudes, either in shallow water on the continental shelf or in somewhat deeper water adjacent to the shelf (miogeosyncline).

(4) Structure: Deposits are in tectonically very stable regions and in structural or topographic basins that were open to deep-sea circulation and where clastic deposition was at a minimum.

(5) Form: Deposits are bedded and may cover thousands of square kilometers. The phosphate grains in the deposits characteristically are pelletal, and the phosphate mineral is always carbonate fluorapatite.

The phosphate deposits of the Atlantic Coastal Plain of the United States exhibit all of these factors. They constitute a large phosphogenic province that extends from southern Florida into southern Virginia and includes the adjacent Continental Shelf of the Atlantic Ocean. The deposits are in the marine, shallow-water Miocene Hawthorn and equivalent Pungo River Formations. They are on the stable platform in basins on the flanks of positive areas; their locations suggest that phosphorus could have been supplied by cool, southward-moving nearshore currents that were turbulently mixed with the warmer waters of the Gulf Stream. The deposits are unconsolidated, the phosphate is pelletal, and the phosphate mineral is carbonate fluorapatite.

Identified resources in the onshore part of this phosphogenic province are about 8 billion metric tons of phosphate pellets that contain an average of about 30 percent $\mathrm{P}_{2} \mathrm{O}_{5}$; identified resources offshore are about 6 billion tons of similar material. Total resources of potentially recoverable phosphate pellets must be scores to hundreds of billions of metric tons. Tonnage data are for phosphate concentrate-that is, pellets that can be recovered by metallurgical techniques. Phosphate mines in Florida and North Carolina account for about 85 percent of the U.S. production and for slightly more than one-fourth of the world's production of phosphate rock. 


\section{GEOLOGIC AND HYDROTHERMAL CHARACTERISTICS OF THE GORDA RIDGE}

\section{David A. Clague and Mark Holmes}

The Gorda Ridge, an oceanic spreading center with a full spreading rate of about $5.5 \mathrm{~cm} / \mathrm{yr}$, is within 200 nautical miles of the coast of northern California and southern Oregon. The ridge consists of three segments of ridgecrest offset by short transform fault zones or overlapping spreading centers. A short chain of seamounts trends northwesterly from a point on the ridge at about $42^{\circ} \mathrm{N}$. The entire ridge is only 160 nautical miles long, and the southern 50 nautical miles is covered by turbidites. The ridge axis is unusually deep, ranging from $3,200 \mathrm{~m}$ to over 3,800 meters deep. The axial graben has from 800 to more than $1,400 \mathrm{~m}$ of vertical relief from the axis floor to the tops of inward-facing fault scarps. Single-channel seismic profiles show the irregular surface of the 5- to 10-nautical mile-wide valley floor; in other crossings the central depression is a sharp notch. The depth to the valley floor varies systematically; the shallowest crossings are at about $42^{\circ} 45^{\prime} \mathrm{N}$., $42^{\circ} 17^{\prime} \mathrm{N}$., and $41^{\circ} 42^{\prime} \mathrm{N}$. Multichannel seismic reflection profiles show that the surface sediments in the Escanaba Trough are cut by faults and demonstrate that the region is undergoing active extension. The discontinuous nature of the basement reflector may be due to sills intruded into the sediment. SeaMARC II side-scan imaging shows individual young lava flows, volcanic cones in the axial valley, and linear fractures on the inner valley walls.

Mid-ocean ridge basalt was recovered in 15 dredges along the northern two-thirds of the ridge. All recovered samples are pillow lavas; no lobate or sheet flow fragments were recovered. A number of the lavas have very fresh glass with little or no palagonite present. Most dredges recovered several lava types, which suggests that the lava flows along much of the Gorda Ridge are small in areal extent and therefore in volume.

Many of the lava samples have thin coatings of hydrogenous Mn-oxides; other deposits and alteration products have a higher temperature hydrothermal origin. Alteration products include smectite, albite, quartz, and $\mathrm{Mn}$ - and Fe-oxides. Minerals of hydrothermal origin include chlorite, gypsum, barite, talc, boehmite, kaolinite, K-feldspar(?), and sulfide phases. The sulfide phases occur as deposits along fractures and include pyrite and pyrrhotite with manganosiderite, and pyrite and sphalerite with barite.

Sediment samples recovered along the ridge axis contain a small amount of hydrothermal Mn. These samples also contain abundant benthic foraminifers and other larger fauna. A massive deposit of hydrothermal nontronite was sampled at $41^{\circ} 31^{\prime} \mathrm{N}$. This deposit is similar to other seabed hydrothermal deposits and probably formed from $20-50^{\circ} \mathrm{C}$ fluid.

Hydrothermal activity is widespread along the axis of the northern two-thirds of the Gorda Ridge. Nearly all the evidence indicates rather low temperature activity with the possible exception of the sparse sulfides, sulfates, and talc deposits from $42^{\circ} 28^{\prime} \mathrm{N}$. We have no data that suggest how long-lived these hydrothermal systems may be, if they are currently active, or if massive sulfide deposits are present.

\section{VOLCANIC AND HYDROTHERMAL SYSTEMS: EARLY PROTEROZOIC MASSIVE SULFIDE DEPOSITS, BAGDAD, ARIZONA}

\section{Clay M. Conway, Thomas J. Connelly, ${ }^{6}$ and Lori C. Robison}

A cluster of $\mathrm{Zn}-\mathrm{Cu}$ massive sulfide deposits at Bagdad, Arizona, is hosted in an Early Proterozoic (about $1740 \mathrm{Ma}$ ) 3-km-thick submarine volcanic succession. A lower basalt is overlain by rhyolite, which intertongues with and is overlain by mixed volcanic, volcaniclastic, and sedimentary rocks. This overturned stratified section constitutes a steeply dipping homocline with little internal folding and faulting. Metamorphism to lower amphibolite facies occurred before $1700 \mathrm{Ma}$.

The main ore bodies of the district (Old Dick, Bruce, Copper Queen) and cross-cutting faults and breccia zones are marginal to a central bulge in the exposure belt of rhyolite. Major alteration zones lie both within and next to the rhyolite bulge. Granophyre semiconformably intrudes the basalt close to the base of the rhyolite bulge. Offset apparently decreases upsection on one fault, and breccia zones are apparently fault controlled, evidence that faulting and brecciation were contemporaneous with volcanism.

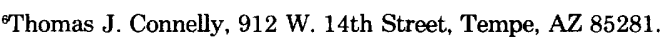


Several types of alteration occur in the area. Epidote-quartz alteration $(+\mathrm{Si},+\mathrm{Ca},-\mathrm{K},-\mathrm{Na}$, $-\mathrm{Fe},-\mathrm{Mg}$, -base metals) is a widespread semiconformable alteration in the basalt. Chlorite alteration $(+\mathrm{Fe},+\mathrm{Mg},-\mathrm{Si},-\mathrm{Ca},-\mathrm{K},-\mathrm{Na}$, +base metals), locally imposed on earlier epidotequartz alteration, has affected both basalt and rhyolite but is more common in basalt. Quartzsericite alteration $(+\mathrm{Si},+\mathrm{K},-\mathrm{Fe},-\mathrm{Na},-\mathrm{Ca})$ is the most common alteration in rhyolite and is most intense in the upper parts of rhyolite lenses.

The rhyolite bulge, faults, breccia zones, and granophyre suggest the presence of a felsic volcanic center. Heat from shallow magma may have driven hydrothermal systems, which altered stratified rocks and formed sea-floor sulfide deposits as volcanism progressed. The range of alteration types in the area may reflect variation in space and time of an evolving long-lived volcanohydrothermal system.

Two different hydrothermal systems probably controlled ore formation at the Old Dick-Bruce and the Copper Queen deposits. The Old Dick-Bruce ore bodies lie at the basalt-rhyolite contact, above a series of stacked chlorite lenses in the basalt. Thin layers composed of varying amounts of sulfides, sericite, and chert are common at the tops of the chlorite lenses. These features are interpreted as resulting from continuous hydrothermal activity, including exhalation on the sea-floor, during repetitive deposition of basalt flows and volcaniclastic material. The system culminated in the formation of the Old Dick and Bruce ore bodies in a period of quiescence between basalt and rhyolite volcanism. The Copper Queen deposit, on the other hand, lies above highly silicified rhyolite and has little associated chlorite. Silicified upper parts of rhyolite layers may have been sealed caps of hydrothermal systems. Massive sulfides (such as the Copper Queen deposit) and spatially related breccia zones may have formed when these caps ruptured and allowed venting of hydrothermal fluids.

\section{CHARACTERISTICS OF AND EXPLORATION FOR Sn-W GRANITES IN THE PRECAMBRIAN ARABIAN SHIELD}

\section{Edward A. du Bray}

Peraluminous granitoid plutons emplaced in the eastern part of the Precambrian Arabian
Shield between 580 and $570 \mathrm{Ma}$ are similar in geology, geochemistry and petrology to metallogenically specialized granites. Most of the plutons are about $15 \mathrm{~km}^{2}$ in areal extent, but several are as large as $75 \mathrm{~km}^{2}$. Geochemical data indicate that the plutons contain anomalous abundances of $\mathrm{Sn}, \mathrm{W}$, and other rare metals and may have associated ore deposits. The plutons were identified by integrated evaluation of geologic, geochemical, petrographic, and geophysical data.

The ten plutons studied are composed of allotriomorphic inequigranular subsolvus alkalifeldspar granite that contains an Fe-Li mica, fluorite, topaz, zircon, and ilmenite. Several contain traces of almandine-spessartine garnet. The major-element chemistry of the granites is like that of experimentally determined granite minimum-melt compositions: they contain more than 75 percent $\mathrm{SiO}_{2}$; are low in total iron, $\mathrm{CaO}$, $\mathrm{TiO}_{2}$, and $\mathrm{MgO}$; and are peraluminous. These granites are significantly enriched in the incompatible trace elements $\mathrm{Be}, \mathrm{Pb}, \mathrm{Sn}, \mathrm{Li}, \mathrm{F}, \mathrm{Rb}, \mathrm{Y}$, and $\mathrm{Nb}$ but, in comparison to average low-Ca granite, are depleted of the compatible elements $\mathrm{Ba}, \mathrm{Cu}$, and Sr. Pan concentrate samples from drainage areas underlain by these plutons contain highly anomalous abundances of $\mathrm{Sn}$ and unusual abundances of $\mathrm{W}, \mathrm{Mo}, \mathrm{Ag}, \mathrm{Pb}, \mathrm{Zn}$, and $\mathrm{Bi}$.

Common-lead isotope data suggest that the granites include a component generated by partial melting of pre-existing continental crust. Majorelement chemical and petrographic data are consistent with crystallization of these plutons under conditions of $P_{\mathrm{H}_{2} \mathrm{O}}=2-4 \mathrm{kbar}$. Trace-element contents indicate that the granites evolved by fractional crystallization and must represent a very small percentage of the primary liquid.

Most of the plutons have been eroded to a moderate level and, lacking evidence of mineralization other than scattered quartz-wolframite veins, it is assumed that cupola zones possibly bearing $\mathrm{Sn}$ or $\mathrm{W}$ have been removed. However, the most northerly pluton is in a less deeply eroded area and forms part of a subcaldera ring complex. Cupola zones in this granite are greisenized and contain notable concentrations of cassiterite.

Exploration for possible Sn-W-bearing plutons commenced with stream-sediment and whole-rock sampling, which established the geochemical affinities of the plutons. Stream sediments were panned until samples had a color index of 50 , most magnetite was removed with a 
hand magnet, and the samples were analyzed for 30 elements by semiquantitative emission spectrography. Whole-rock samples were analyzed by semiquantitative emission spectrography, energydispersive X-ray fluorescence for several diagnostic elements, and wet-chemical methods for fluorine and lithium. Statistical analysis of the geochemical data enabled determination of background and anomalous abundances of each of the elements determined, for comparison with the chemical characteristics of known Sn-W mineralized plutons. Petrographic study of thin sections and modal analysis of stained slabs indicated the mineralogic and textural character of the plutons. Plutons determined by these analyses to be likely sites of mineralization are later explored for ore deposits.

\section{DEPOSITIONAL MODEL FOR SODIUM CARBONATE DEPOSITS IN THE GREEN RIVER FORMATION}

\section{John R. Dyni}

Five separate saline facies are recognized in kerogenous fine-grained lacustrine rocks of the Eocene Green River Formation that were deposited in four basins in Colorado, Wyoming, and Utah. Each facies consists of carbonate-bearing minerals of calcium, magnesium, and sodium, and, in three facies, halite. Differences in mineral solubilities and in composition, temperature, $\mathrm{pH}$, and $P_{\mathrm{CO}_{2}}$ of the lake waters resulted in spatial zonation and speciation of the saline minerals in each facies. The generalized sequence of minerals from the lake margin to the depocenter is (1) dolomite, ankeritic dolomite, (2) shortite, dawsonite, (3) trona or nahcolite, and (4) at the depocenter, halite mixed with trona or nahcolite, wegscheiderite, sparse searlesite, and rarely eitelite and northupite.

Primary sulfate minerals are virtually absent in all five saline facies, even though probable source areas for Green River sediments suggest that sulfate was a common solute in stream waters emptying into the Green River lake system. Iron sulfide minerals are ubiquitous in the saline facies in amounts of about 1-2.5 weight percent. Smectite and illite, the chief clay minerals in profundal sediments of the Green River Formation in Utah and Colorado, decrease in abundance toward the saline depocenters. This decrease may be due to hydrolysis of the clay minerals and neoformation of dawsonite and quartz or to nondeposition.

Principal elements of a proposed depositional model for these saline deposits are (1) a closed basin containing a permanent body of water with anoxic bottom conditions, (2) abundant nutrients and relatively warm lake waters for high productivity of algae and bacteria, (3) a substantial but finite supply of sulfate, (4) a sustained high rate of bacterial reduction of sulfate with metabolic oxidation of organic matter, and (5) a relatively large $\mathrm{Na} /(\mathrm{Cl}+\mathrm{Ca})$ ratio in the lake waters.

Some predrilling guidelines for exploration of new deposits of sodium carbonate analogous to those of the Green River Formation include (1) evidence of water-soluble evaporite minerals in outcrops, such as vugs, crystal cavities, and solution breccias, (2) hydrologic evidence of dissolution of evaporite minerals at depth, (3) areal zonation of alkaline-earth to alkali-metal carbonate minerals that might point toward centers of evaporite deposition, (4) kerogen-rich sediments, and (5) seismic and gravity profiles across a basin to detect salt sequences, delineate basin structure, and locate basin depocenters.

\section{THE ROLE OF REGIONAL SUBSURFACE GEOCHEMISTRY IN RESOURCE ASSESSMENT IN THE CENTRAL UNITED STATES}

\section{R.L. Erickson, E.L. Mosier, J.G. Viets, and M.S. Erickson}

Regional subsurface geochemical studies are an integral part of the U.S. Geological Survey program for assessing the mineral resource potential of platform carbonates in the Central United States. Much of this area is flat to gently rolling agricultural land, outcrops are few, and the known favorable host rocks are at depths ranging from a few hundred meters to more than a kilometer. Thus, traditional surface geochemical techniques are of little use in this area for evaluating the potential for the occurrence of concealed or undiscovered mineral deposits.

Geochemical studies of subsurface Cambrian strata in the Rolla $1^{\circ} \times 2^{\circ}$ quadrangle, Missouri, completed in 1980 , and current geochemical studies in the Springfield, Joplin, and Harrison $1^{\circ} \times 2^{\circ}$ 
quadrangles, which cover about $80,000 \mathrm{~km}^{2}$ in parts of Missouri, Kansas, and Arkansas, indicate that insoluble residues of carbonate rocks are a useful and informative geochemical sample medium in a carbonate environment. Commonly, the amounts of metals in carbonate rocks are very low, sometimes below spectrographic detection limits, and the rock appears geochemically "barren." However, traces of sulfide minerals present in the whole-rock samples are enhanced manyfold in the insoluble residue of those samples. The enhancement of the metal contents and the large suite of metals detectable in insoluble residues offer some hope of determining, on a regional basis, whether or not metal-bearing fluids have passed through the rocks in a given area and have left behind a faint trace of their passage. That faint trace, enhanced, may lead to the discovery of unsuspected subsurface mineral trends where metals such as $\mathrm{Pb}, \mathrm{Zn}, \mathrm{Cu}$, and Co were precipitated in significant quantity from migrating fluids.

The distribution of drill holes that have the largest amounts of $\mathrm{Pb}, \mathrm{Zn}, \mathrm{Cu}, \mathrm{Ni}, \mathrm{Co}, \mathrm{Mo}$, and $\mathrm{Ag}$ in insoluble-residue samples of otherwise apparently metal-barren carbonate rocks outlines the known mineralized trends in the Rolla quadrangle (for example, the Viburnum Trend). Use of this technique in the adjacent quadrangles has resulted in the detection of a new and untested belt of favorable ground for possible mineral discovery in southern Missouri and northern Arkansas. Regional distribution and abundance patterns of molybdenum for much of Missouri south of the Missouri River suggest that a broad molybdenumrich province in subsurface Cambrian rocks extends across southern Missouri and probably into northern Arkansas, an area of perhaps $25,000 \mathrm{~km}^{2}$.

The distribution and abundance patterns of metals in insoluble-residue samples also place some constraints on any model developed to explain the transport and deposition of metals in the carbonate-hosted lead-zinc deposits in this part of the midcontinent. Although basal sandstones are thought by many investigators to have been the principal aquifers for ore fluids before they were introduced into carbonate host rocks, our work indicates that regional fluid transport of metals occurred in porous, permeable zones in carbonate rocks as well as in basal sandstones. Further, we have demonstrated that fluids that brought metals to sites of deposition through the various flow channels were not of uniform composition.
GEOPHYSICAL EXPLORATION FOR BRECCIA PIPES

ON THE COLORADO PLATEAU OF NORTHERN ARIZONA

\author{
Vincent J. Flanigan and Carl L. Long
}

Exploration for hidden breccia pipes in the sedimentary rocks on the Colorado Plateau of northern Arizona has proven to be an interesting and difficult geophysical problem. The breccia pipes are believed to have formed as a result of solution collapse within the Redwall Limestone and stoping of the overlying strata. Copper, uranium, lead, zinc, and silver are the metals found in mineralized breccia pipes, although an extensive suite of other elements is more abundant at the pipes than in the Paleozoic and lower Mesozoic host formations. Numerous pipes have been mapped along canyon walls where they are partially exposed, but they are much more difficult to recognize on the plateau itself. Several geophysical methods have been tested over known breccia pipes in order to characterize the geophysical properties associated with breccia pipes and to evaluate the methods as exploration tools for hidden pipes. The most diagnostic methods are magnetic measurements, telluric profiling, and time-domain electromagnetic (TDEM) profiles and soundings. Audio-magnetotelluric soundings give a good picture of the electric section but are less diagnostic for pipe location than the methods mentioned above, most probably because of low horizontal resolution of the method. Shallow-sounding electromagnetic methods, such as VLF (very low frequency communication signals) and slingram, and gravity methods were less effective at the sites tested.

One site, generally considered a stratabound copper prospect, was chosen to illustrate the results that are to be expected from a breccia pipe of about $200 \mathrm{~m}$ diameter. This site is characterized by a small magnetic low (5-10 nT) surrounded by short-wavelength highs and lows. Telluric data using 50-m E-lines (grounded electric lines) operating at $7.5-27 \mathrm{~Hz}$ suggests a conductive zone coinciding with the short-wavelength magnetic anomalies. A TDEM profile across the pipe reveals a response that compares favorably with modelled TDEM responses over a conductive cylinder. The data are interpreted to be the geophysical response of a central core or plug of Kaibab Limestone surrounded by a $50-\mathrm{m}$-wide fracture zone. The circular 
fracture zone surrounding the breccia pipe is more conductive than unfractured rocks. Magnetic minerals, most likely magnetite, deposited in the fracture zone are the source of the short-wavelength magnetic anomalies. Ground magnetic data mathematically continued upward to aircraft flight height $(100 \mathrm{~m})$ indicate that a $10-\mathrm{nT}$ magnetic low at ground level would appear in an airborne survey as a magnetic low of somewhat less than half the ground level value, and the character of the shortwavelength anomalies would be altered accordingly. To detect such magnetic anomalies from the air, however, would require the use of a highsensitivity magnetometer and closely spaced (50-100 m) flight lines. A high-precision magnetometer airborne survey could locate exploration targets, which could then be followed up by reconnaissance telluric profiles and detailed magnetic and TDEM measurements.

Regional airborne magnetic data provide several clues that may be used as exploration criteria in locating breccia pipes in tree-covered areas on the Colorado Plateau. Predominant basement magnetic trends in the study area are northeast, and secondary trends are north-south and northwest. These magnetic anomalies are thought to be due to intrusion of basic rocks along basement fault zones; these faults were probably important for the karst development in the Redwall Limestone. Exploration should be concentrated along basement magnetic trends, especially at intersections of northeast and northwest basement structures inferred from the magnetic data.

\section{THE SETTING AND DISTRIBUTION OF COPPER-NICKEL SULFIDES IN THE SOUTH KAWISHIWI INTRUSION, DULUTH COMPLEX, MINNESOTA}

\section{Michael P. Foose}

The Duluth Complex in northeastern Minnesota is a composite mafic intrusion that contains large amounts of low-grade copper-nickel sulfides. These magmatic sulfides differ from most others by being relatively young $(1.1 \mathrm{Ga})$ and by having formed within a rift setting. Study of one part of this complex, the South Kawishiwi intrusion, shows that the sulfides form a discrete zone underlying sulfide-free rocks. The sulfide-free zone, which exceeds $3,500 \mathrm{~m}$ in thickness, is mostly troctolite containing laterally persistent anorthosite layers. These layers are parts of cyclic units formed by repeated crystallization of plagioclase followed by plagioclase plus olivine. Chemical variations associated with the cycles show trends both normal and reversed to those typical of fractional crystallization. These trends and the absence of systematic chemical evolution within the sulfide-free zone are consistent with crystallization of this zone in an open magmatic system such as would be expected in an active rift environment in which the magma chamber was virtually continuously replenished by liquids of slightly different compositions.

In contrast, the lower (70- to 200-m-thick) sulfide-bearing zone is a heterogeneous mixture of troctolite, picrite, dunite, anorthosite, oxide cumulates, and hornfels in which sulfides are ubiquitously disseminated. The sulfide-bearing zone is interna1ly chaotic, and its contact with the sulfidefree zone is sharp. Unlike the overlying rocks, the sulfide-bearing zone was emplaced in a physically restricted environment in which repeated surges of magma associated with the initial stages of intrusion caused complete disruption of the internal stratigraphy.

The sulfides are predominantly pyrrhotite, chalcopyrite with cubanite, and pentlandite. Most sulfides occur interstitially between euhedral olivine or plagioclase or are included in rims of silicates. These relations show that sulfide formed after most silicates had accumulated. The close association of sulfides with hydrous phases or with grains that show reverse compositional zoning further indicates that volatiles were important in their formation. The few available isotopic analyses confirm a nonmagmatic source for at least some of the sulfur. Footwall rocks in this intrusion are granite, but abundant metasedimentary inclusions are present throughout the lower zone and show either that sulfide- and volatile-bearing sedimentary rocks once formed the footwall or that large amounts of these rocks were entrained in the initial magma injections. Dispersion of these xenoliths during emplacement of the basal zone largely controlled the appearance of disseminated and sporadically distributed sulfides.

Faulting was active from the onset of intrusive activity and continued to be active during and after magma consolidation. Offsets are mostly small and show variable directions of displacement, but the overall sense of movement is downwards to the southeast, a pattern that is consistent with the area's setting on the northwest 
flank of a regional rift system. The early faulting controlled the form of the basal contact and made troughs in which thicker sequences of sulfidebearing rocks accumulated. Offsets associated with later faulting disrupted layers and juxtaposed diverse groups of rocks. These later offsets may also affect the lateral continuity of the sulfide mineralization.

\section{HEAT TRANSFER AND BRINE EVOLUTION IN MAGMA-HYDROTHERMAL SYSTEMS}

\section{Robert O. Fournier}

There are many uncertainties in the mechanism (or mechanisms) by which heat is transferred from magma to a surrounding hydrothermal system. Mechanisms that have been proposed include (a) conduction, (b) transfer of heat by movement of water and volatiles out of the magma, and (c) circulation of meteoric water into a thin zone of thermal cracking that migrates inward towards the magma with time as the rocks cool. Several recent investigations have focussed upon the likely significance of this last mechanism, but major aspects are poorly understood. Among these are the thickness of the cracking zone, the temperature gradient across it, the temperatures at which it occurs (perhaps $350-450^{\circ} \mathrm{C}$ ), and the chemical consequences of water-rock interaction in that zone. More than one convection cell may be present at a given time within an active hydrothermal system, with fluids of varying composition associated with different types of mineralization in the various cells. Convecting hydrothermal systems at hydrostatic pressure may partly surround hydrothermal systems in which fluid pressures are greater than hydrostatic but less than or equal to the least principal stress in the rock. Fluid pressures greater than hydrostatic are particularly likely to develop where the flow of fluid away from a heat source is impeded by a barrier of relatively impermeable rock, perhaps a layer of very ductile material such as shale in otherwise brittle rock, or a zone where mineral deposition has filled all or most of the pre-existing fractures and pore spaces.

Our present knowledge of hydrothermal mineral deposits and active geothermal systems demonstrates the importance of interaction between shallow dilute meteoric water and deeper brines. The highly concentrated brines thus far encountered in active hydrothermal systems are all

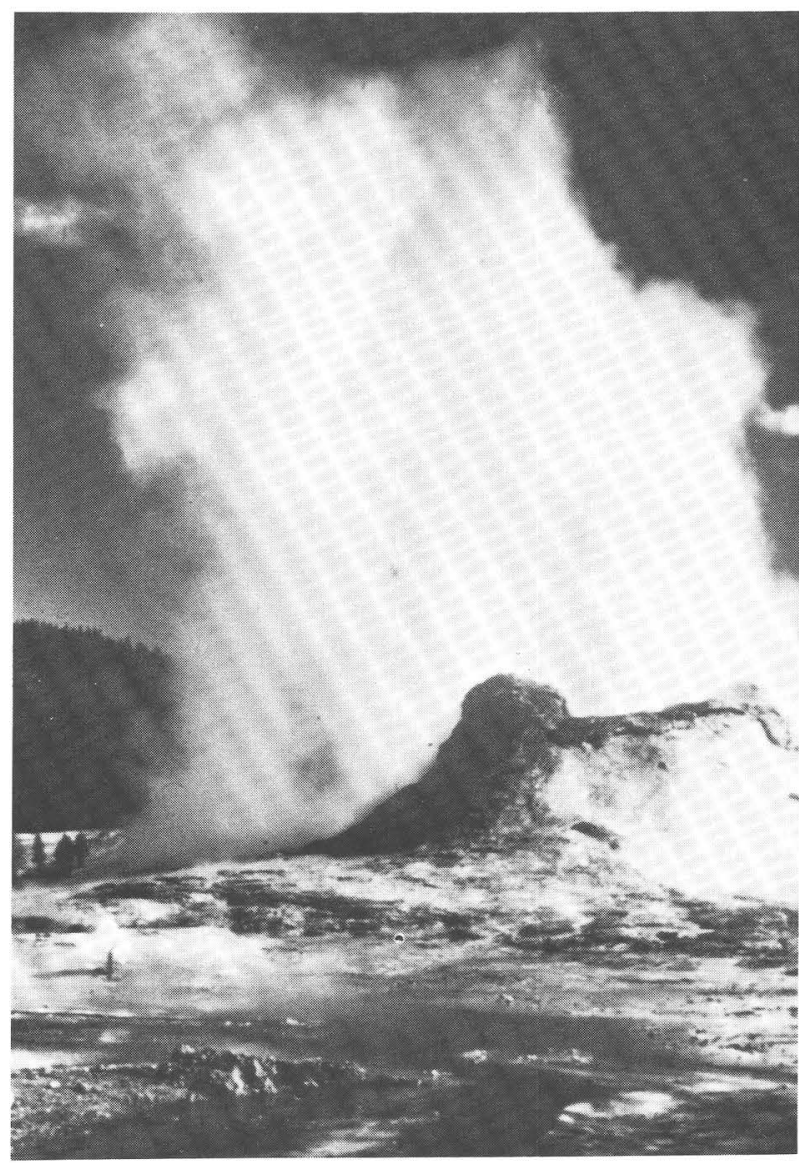

Castle Geyser, Yellowstone National Park, Wyoming

in environments in which the waters may have interacted with evaporites. Experimental data, however, indicate that highly saline as well as moderately concentrated brines may evolve from a crystallizing magma, depending on the initial water and chloride contents and the depth of crystallization. Brines may also develop from dilute meteoric water as a result of boiling, which disproportionates the fluid into a more concentrated liquid (brine) and a gas. As a result of boiling or gas disproportionation, highly saline brines are likely to evolve in and around shallow magmatic intrusions, particularly at depths less than 6 to $8 \mathrm{~km}$. Because of density contrasts, hot brines will remain below hot, dilute, hydrothermal waters or to the side of cold, dilute waters. These hot brines will scavenge metals from the surrounding rock, and the base metals in turn will react with much of the sulfur that is liberated from crystallizing magma. Thus, a base-metal ore deposit may form in the brine part of the hydrothermal system while the dilute part remains relatively unmineralized with respect to base metals. 


\section{GEOLOGY AND GEOCHEMISTRY OF WALL ROCKS OF APPALACHIAN MASSIVE SULFIDE DEPOSITS}

\author{
Jacob E. Gair
}

During the past few years, distinctive mineral and chemical compositions have been noted in wall rocks of a number of Appalachian massive sulfide deposits. Such compositions also appear to be associated with many massive sulfides in other areas.

Wall rocks of sediment-hosted massive sulfides in the Gossan Lead district, Virginia, and at Ducktown, Tennessee, are parts of thick flyschoid metagraywacke-schist sequences deposited in craton-margin rifts with or without substantial mid-ocean-ridge-type basalt (MORB). Adjacent to the sulfide bodies, lenses of the wall rock commonly are of unusual composition, containing a high proportion of a single mineral (sodic plagioclase, Mn-garnet, biotite, or muscovite); in places, some lenses are virtually monomineralic. Other lenses contain a large amount of two minerals such as sodic plagioclase and biotite, Mn-garnet and quartz, or Mn-garnet and biotite. In the Gossan Lead district, the Mn-garnet near sulfide bodies contrasts with Mn-poor (almanditic) garnets in the more distant country rocks. Dravitic tourmaline is an important constituent of wall rocks and (or) gangue in a few such sediment-hosted deposits elsewhere in the Appalachians. These minerals reflect metasomatic additions of $\mathrm{Na}, \mathrm{Mn}, \mathrm{K}$, and (or) $\mathrm{B}$ to the normal flyschoid sediments. The association of these added materials and sulfide deposits is attributed to deposition from the same or closely related hydrothermal fluids. Rifts were the sites both of the flyschoid sedimentation and of hydrothermal circulation and mineralization.

Volcanic-hosted massive sulfide deposits in the Appalachians, as in many other places in the world, are preferentially associated with felsic to intermediate calc-alkalic island-arc volcanic rocks. In the Mineral district, Virginia, such volcanic rocks in the walls of the deposits are enriched in the light rare-earth elements (with $\mathrm{La} / \mathrm{Yb}>5$ and commonly $>8$ ) and have $\mathrm{Nb}>7 \mathrm{ppm}$; some of these rocks were residually enriched in $\mathrm{Al}$ by hydrothermal volcanic activity as they formed or shortly thereafter, so that subsequently the aluminous metamorphic minerals, chloritoid and (or) staurolite, formed in them. Kyanite-rich rock at Graves Mountain, Georgia, in the southwestern part of the Carolina slate belt, also has been at-

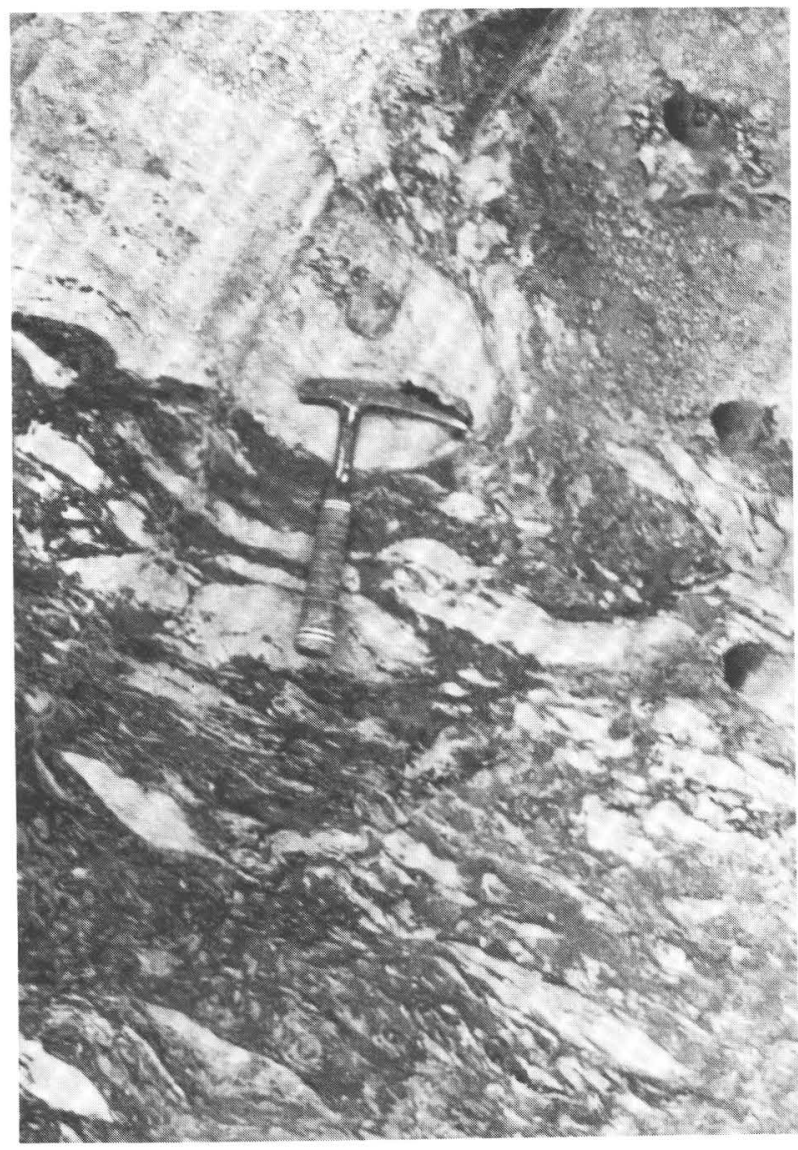

Wall-rock fragments in massive sulfide ore, Gossan Lead district, Virginia

tributed to residual enrichment in $\mathrm{Al}$ by hydrothermal leaching during volcanism, and nearby massive sulfide deposits are considered to be a product of the same hydrothermal activity. Garnet in the wall rocks at Mineral is rich in $\mathrm{Mn}$, but whether this contrasts with garnet compositions in country rock distant from the deposits, as in the Gossan Lead district, has not yet been determined.

In appropriate (meta)volcanic or (meta)sedimentary terranes, the discovery of rocks, mineral concentrations, or geochemical anomalies consistent with the features described here can aid in targeting massive sulfide exploration.

\section{EPISODIC METALLIZATION IN THE WESTERN SAN JUAN CALDERA COMPLEX, COLORADO}

\section{R.I. Grauch, Ken Hon, R.L. Reynolds, D.J. Bove, and V.J.S. Grauch}

Base- and precious-metal (BPM), Mo, U, Al, and $\mathrm{Sn}$ concentrations in volcanic and intrusive 
host rocks are spatially and temporally related to the evolution of the Lake City and Uncompahgre calderas of the western San Juan volcanic field, Colorado. The Uncompahgre caldera forms the eastern half of the Uncompahgre-San JuanSilverton caldera complex, which collapsed and resurged between 27 and $29 \mathrm{Ma}$ to create the northeast-oriented Eureka graben along the crest of the resurgent dome. Nested within the Uncompahgre caldera is the younger Lake City (LC) caldera, which collapsed following the eruption of the Sunshine Peak Tuff, a 23.1-Ma, compositionally zoned intracaldera ash-flow sheet ${ }^{{ }^{87} \mathrm{Sr}}{ }^{86} \mathrm{Sr}=0.7061-0.7068$ and ${ }^{206} \mathrm{~Pb} /{ }^{205} \mathrm{~Pb}=$ 18.55-18.62). Emplacement of cogenetic quartz syenite magma caused asymmetric resurgence of the LC caldera and uplift of at least $1,500 \mathrm{~m}$ along the northern ring fault. Aeromagnetic and gravity data show that exposed quartz syenites represent a single large resurgent intrusion. Paleomagnetic and radiometric data indicate that the time required for caldera development, from eruption of the ash-flow tuffs to emplacement of resurgent intrusions, was less than 300,000 years. During the same interval, post-collapse lavas and a composite dome, the Red Mountain center, were emplaced along the east side of the caldera and were hydrothermally altered. The youngest intrusions in the area are 19-Ma rhyolite porphyry plugs north of the caldera and $17 \pm 0.5-\mathrm{Ma}$ rhyolite porphyry dikes southwest of the caldera.

Elemental distribution patterns $(\mathrm{K}, \mathrm{Th}, \mathrm{Be}, \mathrm{U}$, Mo) show distinct anomalies related to the LC caldera and are generally associated with the Sunshine Peak Tuff. However, more localized and intense geochemical anomalies, combined with variations in spectral reflectivities and in wholerock isotope ratios, clay, and metal contents, define distinct hydrothermal cells within the caldera complex. Major fracture zones, resurgent intrusions, and post-caldera intrusions apparently controlled the distribution of hydrothermal cells and metal concentrations. BPM- and Te-bearing veins associated with $U$ occur west of the LC caldera at Gravel Ridge in structures of the Eureka graben and east of the caldera at the Golden Fleece mine, where the vein yielded a U-Pb isochron age of $27.5 \pm 0.5 \mathrm{Ma}$. Highly radiogenic initial $\mathrm{Pb}$-isotope ratios of ore samples from the Golden Fleece ${ }^{(206} \mathrm{Pb} /{ }^{204} \mathrm{~Pb}=19.078-19.58$; $\left.{ }^{208} \mathrm{~Pb} /{ }^{204} \mathrm{~Pb}=38.533-38.84\right)$ suggest that a significant amount of common lead, and possibly of other metals, was derived from upper crustal Precam- brian rocks by deeply circulating hydrothermal fluids. A near-surface, low-temperature $\mathrm{Au}$-Te deposit at the nearby Golden Wonder mine has much less radiogenic common lead and is thought to have formed as part of a contemporaneous but separate hydrothermal cell. Minor concentrations of BPM, U, and Sn are spatially associated with the resurgent intrusion in the northwest portion of the LC caldera. The Red Mountain alunite deposit, one of the largest in the United States, formed during the same time interval and involved the shallow circulation of large quantities of meteoric fluids in and around the Red Mountain composite dome. Radiometric data suggest that the major BPM deposits of the Lake City District, northeast of the LC caldera, formed at the same time as the Red Mountain deposit. Anomalous concentrations of $\mathrm{Be}, \mathrm{Mo}, \mathrm{U}$, and $\mathrm{F}$ are associated with 19-Ma intrusions north and west of the caldera and with 17-Ma dikes southwest of the caldera. These occurrences and deposits document episodic metallization, over a period of about $10 \mathrm{~m} . \mathrm{y}$., related to the evolution of the western San Juan caldera complex.

\section{AEROMAGNETIC AND GRAVITY MODELS OF THE PLUTON BELOW THE LAKE CITY CALDERA, COLORADO}

\section{V.J.S. Grauch}

Aeromagnetic and gravity data collected over the Lake City caldera, San Juan Mountains, Colorado, were used to calculate models of the pluton below the caldera. Magnetic data are from a draped airborne survey and are in digital form. Gravity data were assembled from the Department of Defense files and were combined with more recent data collected across the caldera. Both data sets were gridded and contoured in map form and also examined in profile form. Regional trends were removed where necessary and data were continued upward mathematically, to enhance the effect of the subsurface pluton over the effects of shallow sources.

Geologic mapping by P. Lipman and more recently by K. Hon, both of the USGS, revealed isolated outcrops of quartz syenite inside the caldera. These workers inferred that these rocks were intruded at the time of resurgence of the caldera. Aeromagnetic and gravity data strongly suggest 


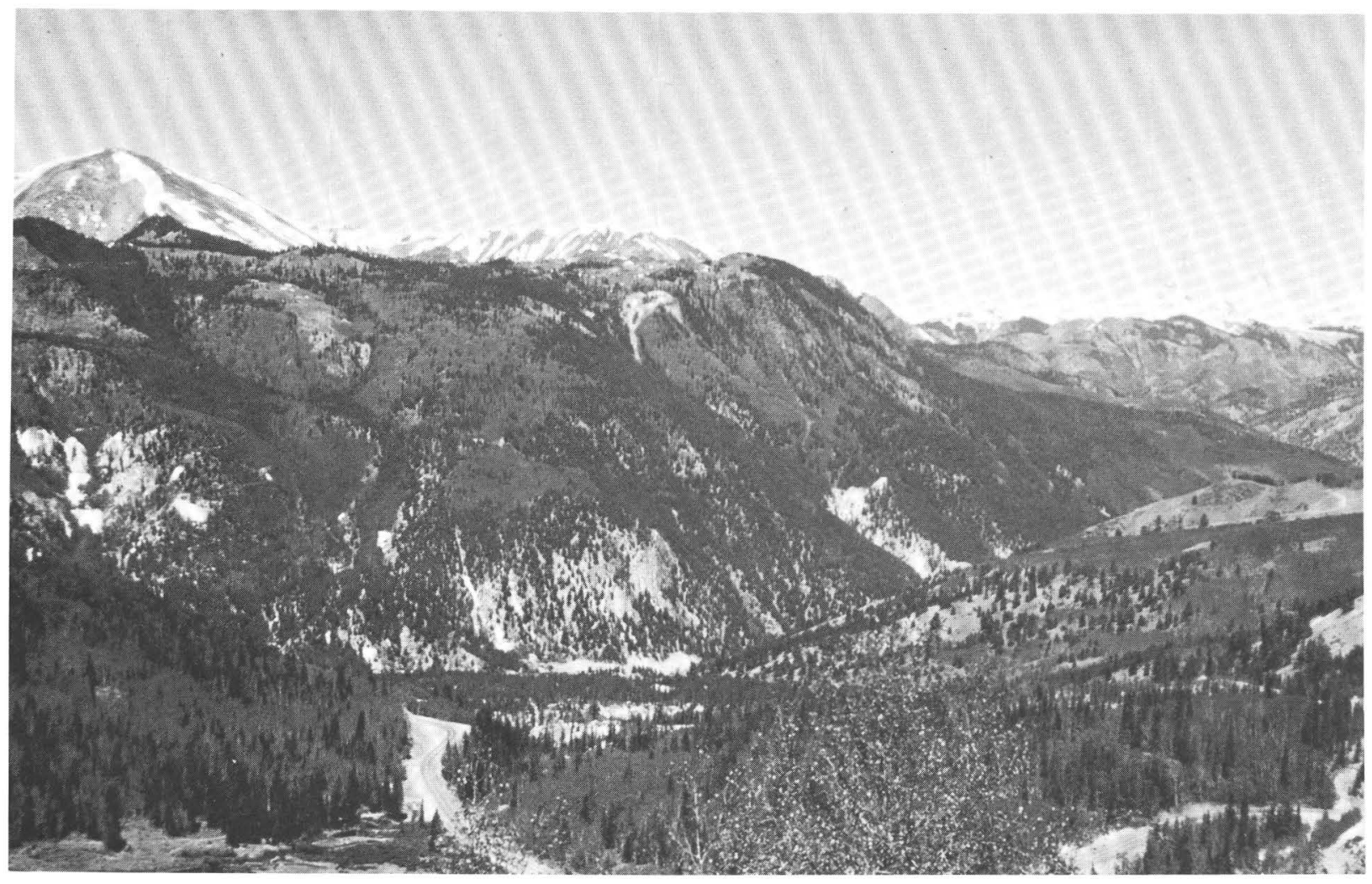

View of Lake City caldera, looking west from Slumgullion Pass. Red Mountain (3,900 m) visible at far left

that the individual quartz syenite outcrops are part of a larger body at depth-the resurgent intrusion. Many of the gold, silver, and uranium occurrences are related to hydrothermal cells inside the caldera, which in turn were controlled by the emplacement of the resurgent intrusion. A model of the top of the intrusion, then, is important to understanding the origin of mineralization.

Models calculated by inverting intersecting magnetic and gravity profiles show a pluton whose top surface is asymmetric; it is shallower in the northwestern part of the caldera and deeper in the southeast. The pluton model extends further east than expected from the geologic evidence. It is more magnetic on the eastern side and also more deeply buried, which might explain the absence of surface geologic evidence for an intrusion on the east. Thus, modelling aeromagnetic and gravity data in caldera areas provides information on subsurface structure that is valuable in determining the evolution and mineralization of the caldera system.

\section{ECONOMIC HEAVY MINERALS OF THE U.S. ATLANTIC CONTINENTAL SHELF}

\section{Andrew E. Grosz, Edward C. Escowitz, S. Jeffress Williams, Ricardo Lopez, John C. Hathaway, Joseph M. Botbol, and Laurence J. Poppe}

The Nation's demand for heavy minerals, including many strategic and critical minerals, exceeds the domestic supply. For example, in 1982 the United States imported 60 percent of the ilmenite and nearly 100 percent of the rutile it required.

In the United States, heavy minerals, such as ilmenite, leucoxene, rutile, zircon, monazite, and other minerals resistant to weathering, have concentrated along fossil beaches, alluvial floodplains, and recent shorelines. Major onshore deposits are located in Coastal Plain sediments of New Jersey, the Carolinas, Georgia, and Florida. Economic concentrations of heavy minerals may also be associ- 
ated with former shoreline and fluvial deposits now submerged on the Continental Shelf.

The Atlantic Continental Shelf (ACS) has an area of about $3.91 \times 10^{5} \mathrm{~km}^{2}$ and probably contains 3-7 $\times 10^{11} \mathrm{~m}^{3}$ of sand and gravel, at an average grade of approximately 1 percent heavy minerals. This preliminary result is in contrast to previous estimates of 0.16 percent heavy minerals in the ACS sand and gravel. Therefore, estimates by others of $1.3 \times 10^{9} \mathrm{~m}^{3}$ of sand bearing heavy minerals are almost certainly low. The USGS is now systematically assessing placer heavymineral resources within the U.S. Exclusive Economic Zone; initial efforts are concentrated on the ACS. The primary goal is to locate heavymineral deposits offshore and to understand the geologic and geochemical factors governing their distribution.

Heavy minerals in 71 grab samples from offshore of well-studied Coastal Plain marine sediments in Virginia, South Carolina, and northeastern Florida were studied. Results indicate that surface grab samples from an extensive area offshore of Virginia, where onshore deposits contain the lowest concentrations measured, have the highest concentrations of heavy minerals, comparable to the richest onshore control area (South Carolina) and even some commercial deposits in Florida and New Jersey. These results are at variance with previously published hypotheses, which state that the best target areas for accumulation of heavy minerals should be situated offshore of known concentrations in onshore sediments.

Other research focused on the ACS includes analyses of more than 500 grab samples (from the USGS-Woods Hole Oceanographic Institution ACS collection) and over 1,200 sediment cores and associated 18,000 line $\mathrm{km}$ of high-resolution seismic reflection profiles (from the U.S. Army Corps of Engineers) to determine the areal and vertical distribution and economic potential of the identified offshore heavy-mineral accumulations. Quantitative analyses of sediment characteristics, bathymetry, and other variables show distinct patterns in areas of the ACS where high heavymineral concentrations are present. These patterns are evident on many parts of the central ACS (Long Island to Cape Hatteras). On parts of the southern ACS (Cape Hatteras to Miami), high heavy-mineral concentrations appear to be limited to the Inner Shelf. Potential economic value of the heavy-mineral concentrations in these areas is be- ing assessed by quantifying the individual mineral species relative to the absolute concentrations and dimensions of deposits. A variable called ECON, which is the sum of weight percent ilmenite, leucoxene, rutile, sillimanite, and monazite in a sample, is used to indicate potential economic value. The mean ECON value for offshore Virginia, for example, is 1.13 percent. However, the ECON reaches values of 4.58 percent in some samples. For comparison, the average ECON value for working deposits in northeastern Florida is about 2 percent.

\section{MINERAL RESOURCES OF THE SURVEY PASS QUADRANGLE, BROOKS RANGE, ALASKA}

\section{Donald J. Grybeck and Steven W. Nelson}

The mineral resources of the Survey Pass quadrangle (mapped at 1:250,000) in the central Brooks Range were evaluated under the Alaska Mineral Resource Assessment Program (AMRAP) beginning in 1977. Like all AMRAP studies, the Survey Pass effort is not a literature search but is based on a comprehensive field program specifically tailored to collect and integrate geological, geochemical, geophysical, and mineral deposit data to achieve a modern (reconnaissance) assessment of the quadrangle's mineral resources.

The essential framework for producing the mineral resource assessment is the geologic map; more than half the effort in the study and considerable scientific talent in several disciplines was devoted to understanding the geology of the quadrangle. The geologic map was then used as the foundation for interpreting and integrating the geochemical, geophysical, and mineral deposit data with ore deposit models to define areas of mineral resource potential. The areas varied greatly in their apparent mineral potential, not only because of differences in their inherent mineral endowment but because of the considerable variation in the amount and the implications of the data that were available.

Seven terranes, bounded mainly by known or suspected north-dipping thrust faults, can be distinguished by stratigraphy, metamorphic grade, structural fabric, and magnetic signature. Almost all the rocks in the quadrangle are known or presumed to be Late Devonian or Early Mississippian in age, although they differ widely in 


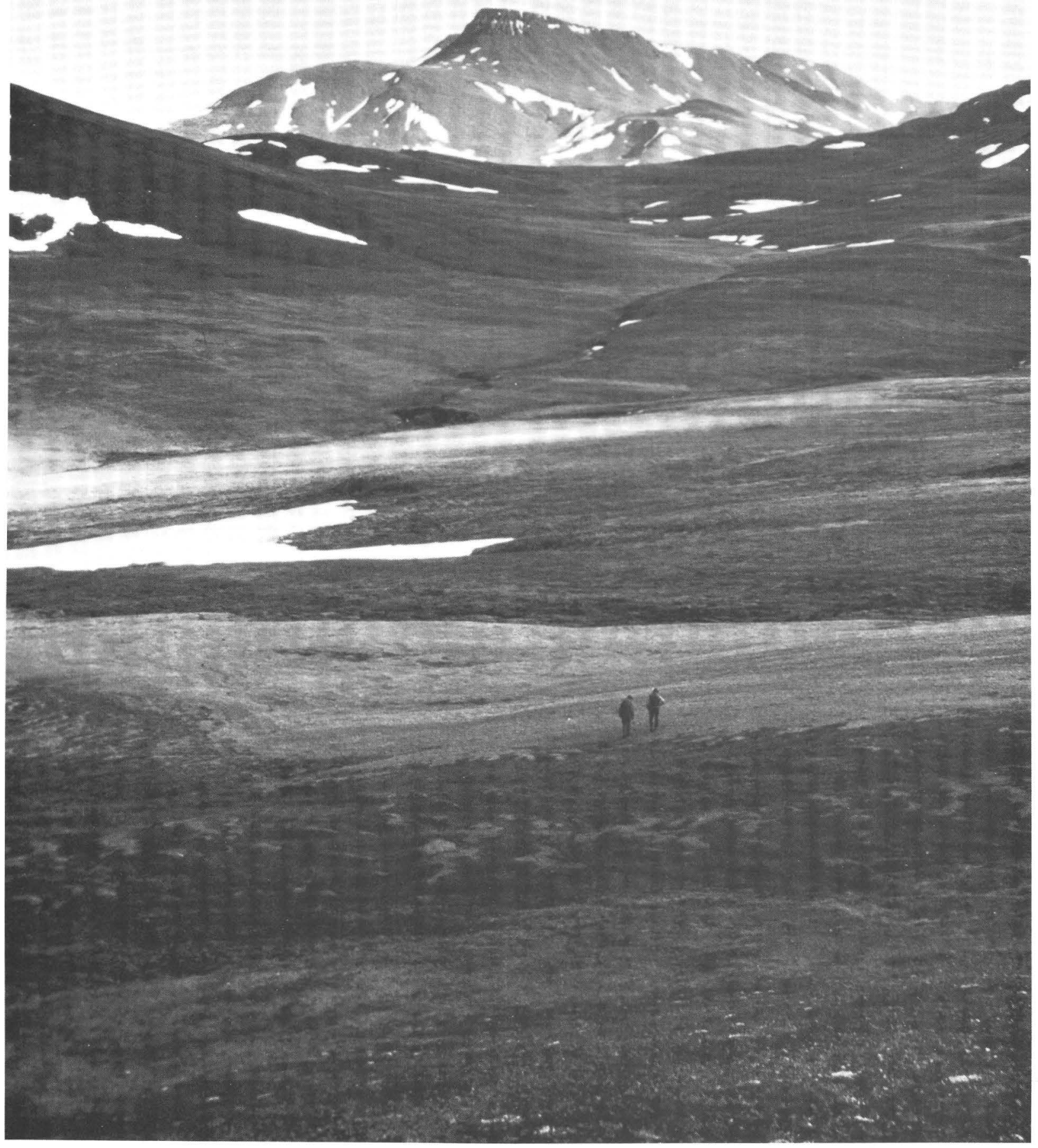

Geologists examining stratiform $\mathrm{Zn}-\mathrm{Pb}$ sulfide deposit at Drenchwater Creek, northwestern Brooks Range, Alaska 
lithology. The northernmost terrane consists mainly of a thick, unmetamorphosed red-bed sequence deposited in a delta that covered much of what is now the Brooks Range in Late Devonian time. South of the red-bed sequence, four terranes consist of unmetamorphosed to low-grade rocks, mainly phyllites, and carbonates. South of them, the central portion of the quadrangle consists of low- to medium-grade calcareous to pelitic schist, gneiss, marble, and quartzite that surround two Devonian gneissic granite batholiths. The southernmost terrane, the "schist belt", consists of lowgrade pelitic schists with scattered occurrences of blueschist. The schist belt also contains a distinctive sequence of felsic and calcareous schist, rhyolite, and mafic igneous rocks, which hosts large volcanogenic massive sulfide $\mathrm{Cu}-\mathrm{Zn}-\mathrm{Pb}(-\mathrm{Ag}-\mathrm{Au})$ deposits.

Only two classes of deposits appear to be of major importance in the quadrangle: the volcanogenic massive sulfide deposits and several types of deposit associated with felsic plutonic rocks. Numerous lines of evidence indicate that additional massive sulfide deposits may exist in the schist belt, but only in its western half in the quadrangle. This study identified many skarn and other contact metamorphic deposits and veins containing various combinations of $\mathrm{Pb}, \mathrm{Zn}, \mathrm{Cu}, \mathrm{Ag}, \mathrm{Au}$, Mo, Sn, W, and other elements around the Devonian granite batholiths, and the geochemical data indicate additional undiscovered deposits of this type. However, all the known deposits associated with the granites are small; most are little more than mineralogical occurrences. While the known granite plutons are an attractive environment for mineral deposits of several types, their roof zones, which were the most likely sites of mineralization, are largely eroded away. However, the geochemical, remote-sensing, and mineral deposit data strongly suggest that at least two large buried and previously unsuspected granitic plutons are present in the northern part of the quadrangle, and several more are suspected elsewhere.

\section{BASE METALS, PRECIOUS METALS, AND MOLYBDENUM: NEW OCCURRENCE TYPES IN THE WESTERN UNITED STATES}

\section{Wayne Hall, Steve Ludington, Ted G. Theodore, and Norman J Page}

Central Idaho Black Shale Mineral Belt (Hall)-A highly mineralized black shale belt $60 \mathrm{mi}$ (95 km) long and 8-30 mi (13-48 km) wide of Ordovician to Permian age crops out on the east side of the Atlanta lobe of the Idaho batholith in central Idaho. These black shales occur in imbricated tectonostratigraphic plates separated by regional thrust faults. Mineralized resources include (1)

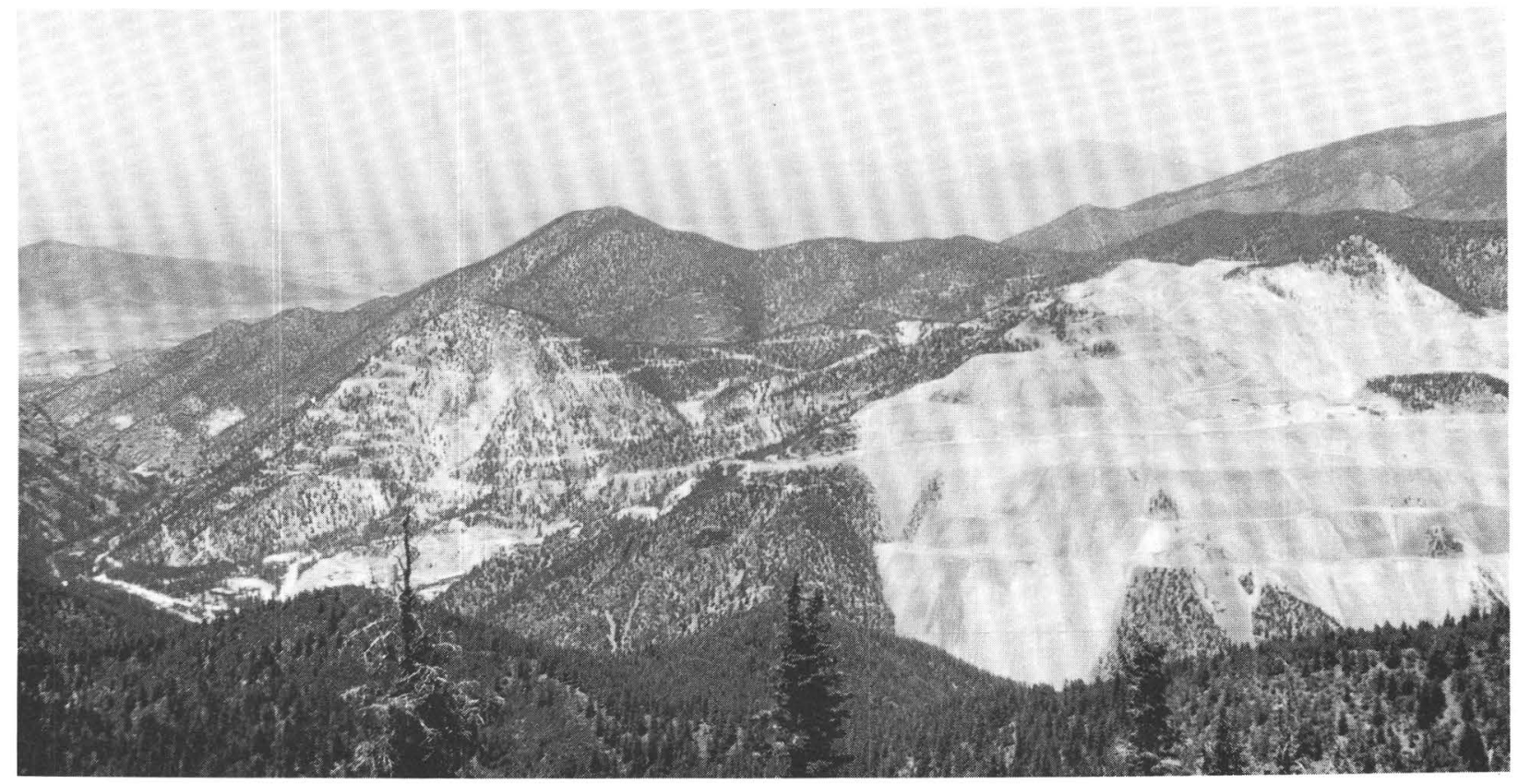

Open-pit molybdenite mine at Questa, New Mexico 
small to moderate-sized high-grade $\mathrm{Pb}-\mathrm{Ag}-\mathrm{Zn}$ vein deposits that account for most past production, (2) two large Mo deposits associated with granodiorite stocks intruded into Mississippian black argillites, and (3) stratabound deposits of $\mathrm{Zn}-\mathrm{Pb}$ $\mathrm{Ag}$, barite, and $\mathrm{V}$, mostly in highly carbonaceous shale and limestone of the Devonian Milligan Formation and Mississippian Salmon River sequence. Geologic, stable-isotope, and fluid-inclusion data indicate that the sources of metals and sulfur for the vein deposits are the host black shales near intrusive bodies. These vein deposits may be used as guides to possible nearby syngenetic deposits.

Questa Molybdenite Deposits (Ludington)-A number of molybdenite deposits near Questa, New Mexico, share many characteristics with models developed for "Climax-type" or "high-fluorine" stockwork molybdenite deposits. To the explorationist, all these deposits belong to the same class; they can be discovered using the same recognition criteria and exploration strategies. However, at Questa, local structural and petrologic criteria suggest a petrotectonic setting and emplacement history different from those of the classic Climax and Henderson deposits. The rhyolite magmas that were the source of the Questa deposits were closely associated with, and may have been derived from, large bodies of calc-alkaline quartz monzonite. Rhyolites at Questa show substantially less enrichment in lithophile elements such as F, $\mathrm{Rb}$, and $\mathrm{Nb}$ that are characteristic of Climax-type deposits; ore bodies at Questa are less regular in shape and are not so clearly related to individual plutons.

Though much field evidence suggests that the Questa deposits formed late in the history of the peralkaline Questa caldera, other evidence (detailed trace-element, isotopic, and geochronologic studies) is compatible with the view that the oreforming events were subsequent to and independent of the caldera cycle.

Gold in two-mica granites (Theodore and Page)-Mesothermal gold mineralization in the Gold Basin district, Arizona, occurs in intensely brecciated veins and in small, high-grade, feldspathic, funnel-shaped alteration zones of episyenite-all associated genetically with Upper Cretaceous two-mica, peraluminous granites. Some veins, such as the one at the Cyclopic mine, probably reflect several stages of brecciation. Initially, flat-lying cap-rock breccias developed in zones of silica deposition above episyenite that formed deep within two-mica granite. Subsequent faulting along low-angle, Miocene detachment surfaces further brecciated the veins. Similar relations between mineralization and tectonics may occur elsewhere in the belt of two-mica granites along the eastern margin of the Basin and Range.

\section{ORGANIC GEOCHEMISTRY OF WALL-ROCK ALTERATION, THOMPSON-TEMPERLY MINE, SOUTHWEST WISCONSIN}

Joseph R. Hatch, Allen V. Heyl, and J. David King

Previous studies of the Thompson and Temperly zinc-lead ore bodies, southwest Wisconsin, show alteration aureoles in the Middle Ordovician host-rock limestones, dolomites, and shales extending laterally as much as $60 \mathrm{~m}$ from the ore. Texture, clay mineralogy, and major-, minor-, and trace-element and $\delta^{13} \mathrm{C}$ and $\delta^{18} \mathrm{O}$ compositions of the host rocks have all been significantly affected by mineralization processes. Fluid-inclusion studies indicate that maximum temperatures of ore deposition were about $120-130^{\circ} \mathrm{C}$.

We performed organic geochemical analyses on samples of the basal 3-inch-thick (8-cm-thick) carbonaceous shale and the immediately overlying limestone bed of the Quimbys Mill Member of the Platteville Formation. The samples were collected from the ore body, the alteration aureole, and unaltered rock. Results and conclusions include the following:

(1) Total organic carbon (TOC) contents in the basal carbonaceous shale are relatively high but range widely, from 1.7 to 6.7 percent. TOC is higher in shale samples from the ore and alteration aureole (mean $=4.2$ \pm 1.3 percent, 12 samples) than in unaltered shale $($ mean $=2.5 \pm 0.7$ percent, 5 samples). In the overlying limestone, TOC is much higher in samples from the ore (mean $=1.5 \pm 1.2$ percent, 5 samples) than in samples from the alteration aureole or unaltered country rock $(0.2 \pm$ 0.06 percent, 11 samples). The higher TOC of samples of limestone within the ore and in the alteration aureole are a result of solution of carbonates and residual concentration of organic matter.

(2) Organic carbon $\delta^{13} \mathrm{C}$ is $-31.2 \pm 0.3$ per mil for the carbonaceous shale (18 samples) and 
$-30.6 \pm 0.3$ per mil for the limestone $(8$ samples). Organic carbon $\delta^{13} \mathrm{C}$ does not change systematically with distance from the ore body in either shale or limestone.

(3) Results from Rock-Eval pyrolysis show that carbon-normalized volatile hydrocarbon (HC) contents $\left(\mathrm{S}_{1} / \mathrm{TOC}\right)$ decrease toward the ore body in both shale and limestone (from about 0.3 to about $0.1 \mathrm{mg} \mathrm{HC} / \mathrm{g}$ TOC) and that carbon-normalized pyrolytic HC contents (hydrogen index, HI, $\mathrm{S}_{2} / \mathrm{TOC}$ ) are much lower in the shale near the ore body ( $\mathrm{HI}=50-250 \mathrm{mg} \mathrm{HC} / \mathrm{g}$ TOC) than in the outer part of the aureole or unaltered rock $(\mathrm{HI}=350-580 \mathrm{mg} \mathrm{HC} / \mathrm{g}$ TOC). In contrast, limestone samples from within the ore body have much higher $\mathrm{HI}$ (HI = 390-460 mg HC/g TOC) than limestone from the aureole or unaltered rock ( $\mathrm{HI}=80-260 \mathrm{mg} \mathrm{HC} / \mathrm{g}$ TOC). The temperature at which the $\mathrm{S}_{2}$ peak reaches a maximum ( $\mathrm{T}_{\max }$ ) ranges from 423 to $432^{\circ} \mathrm{C}$ for all samples, indicating immature to marginally mature organic matter. $\mathrm{T}_{\max }$, however, shows no systematic changes with distance from the ore. The decrease in $\mathrm{S}_{1} / \mathrm{TOC}$ towards the ore indicates loss of lower molecular weight organic compounds during mineralization. The decrease in hydrogen index for the shale indicates alteration of organic matter. The higher hydrogen index of the limestone within the ore may be an artifact caused by concentration of organic matter. The lack of change in $\mathrm{T}_{\max }$ is a probable result of a relatively short time of hydrothermal activity.

(4) Distributions of saturated hydrocarbons extracted from both shale and limestone samples show relative decreases in amounts of lower molecular weight compounds $\left(<\mathrm{n}-\mathrm{C}_{25}\right)$ in and near the ore. This supports the loss of volatile hydrocarbons indicated by $\mathrm{S}_{1} / \mathrm{TOC}$. Biological-marker distributions for all samples are remarkably similar regardless of lithology or proximity to the ore body. Biologicalmarker maturity indicators, $\mathrm{C}_{29}$ sterane $5 \alpha(\mathrm{H}), \quad 14 \alpha(\mathrm{H}), 17 \alpha(\mathrm{H}), \quad 20 \mathrm{~S}$ to $5 \alpha(\mathrm{H})$, $14 \alpha(\mathrm{H}), 17 \alpha(\mathrm{H}), 20 \mathrm{R}$ ratios and $22 \mathrm{~S} / 22 \mathrm{R}$ $\mathrm{C}_{31}$ hopane ratios, are $0.6 \pm 0.1$ and $1.4 \pm$ 0.1 , respectively, and indicate marginally mature organic matter. The lack of effect on the biological marker maturity indicators by the alteration and mineralization suggests a relative short interval of hydrothermal activity; biomarker equilibration apparently requires more time than the duration of Upper Mississippi Valley-type mineralization.

\section{ORIGIN OF SEDIMENTARY HUMIC ACIDS, POTENTIAL CARRIERS OF ORE-FORMING ELEMENTS}

\section{Patrick G. Hatcher}

Humic acids are complex, macromolecular organic components of sediments and are defined by their solubility in dilute alkali and insolubility in dilute acid. Because of their general structural characteristics (for example, their high proportion of oxygen functional groups), humic acids can complex with inorganic cations and may be important in forming ore deposits. In some instances (such as uranium ores), ore bodies are believed to have originated by mobilization of an ore-forming element complexed with humic acids and subsequent precipitation.

Little is known about the mechanisms by which humic acids evolve from sedimentary organic matter. Humic acids were generally thought to be molecular polymerization products of smaller molecules produced by microbial decomposition of plant remains. However, studies of humic acids by nuclear magnetic resonance (NMR) techniques show that they are derived by degradation of macromolecules formed in plants. When compared to these insoluble macromolecules, humic acids in aerobic sediments show many similar structural features, invariably a greater proportion of carboxyl groups, and a tendency to be more aromatic. Carboxyl groups are thought to be introduced during oxidative decomposition of the plant macromolecules. The oxidation products become more soluble in aqueous alkali, resulting in the formation of substances that are operationally classed as humic acids. Very little structural alteration would occur by such oxidation. This proposed pathway is consistent with the observed structural similarity between humic acids and the plant macromolecules as determined by NMR. The increased aromaticity probably results from the 
higher susceptibility of aromatic structures to degradation under oxidizing conditions.

In anaerobic sediments, the production of humic acids is suppressed by the lack of oxidation. In such sediments, materials extracted as humic acids, usually in low yields, bear little structural resemblance to preformed macromolecules. Rather, these humic acids appear to be mostly fermentation products of decomposing plant litter or simply fragments of the soluble plant macromolecules.

Knowing the mechanism by which humic acids originate is fundamental to our understanding of the role of organic matter in ore deposition. We can begin to understand transport of oreforming elements by humic acids only when we know how humic acids originate. The chemical structural composition of humic acids affects their ability to complex with certain elements. The chemical structure of humic acids responsible for formation of a particular ore body must be defined so that we can use this information in predictive models.

Knowledge of the mechanism for the formation of humic acids is being applied to two major ore deposits. Studies of organic matter associated with tabular uranium ores of the San Juan basin and disseminated, Carlin-type gold ores from Nevada show that humic acids may have been precursors. This suggests that the humic acids could have played a major role in the transport and accumulation of the ore. For example, oxygenated ground waters or hydrothermal fluids passing through organic-matter-rich rocks could have oxidized the indigenous organic matter to produce soluble humic acids that subsequently complexed gold or uranium ions. The humic acids carrying these elements could have precipitated in host rocks. During maturation, the humic acids may have lost their oxygen functionality, become insoluble, and lost their complexing ability for metals. These metals released from the organic matter could then become incorporated in mineral phases.

\section{RESEARCH ON KIMBERLITES AND APPLICATIONS TO DIAMOND PROSPECTING}

\section{B. Carter Hearn, Jr., and Elaine S. McGee}

Research on kimberlites in Montana and northern Michigan has concentrated on field mapping, mineralogy of xenocrysts and megacrysts,

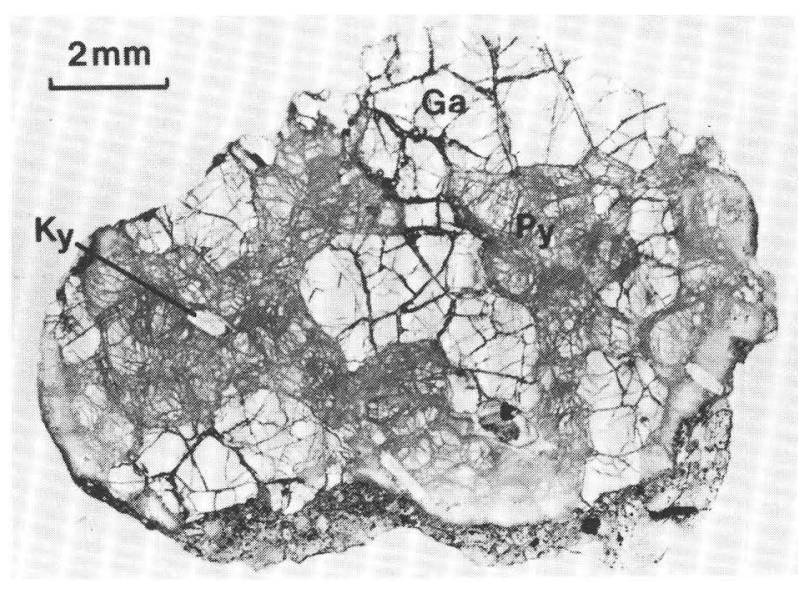

Kyanite-garnet-pyroxene inclusion (kyanite eclogite) from the Lake Ellen kimberlite, northern Michigan; derived from a calculated depth of $115 \mathrm{~km}\left(940^{\circ} \mathrm{C}\right)$ in the upper mantle

mineralogy of upper-mantle peridotite and eclogite xenoliths, and bulk chemical composition. The Montana kimberlites contain no diamonds. Whether the Lake Ellen, Michigan, kimberlite contains diamond is unknown. The Lake Ellen kimberlite is particularly important because primary kimberlite sources for the diamonds found in glacial deposits in the Midwest may lie within the United States rather than in southern Canada.

Because kimberlites typically have poor exposures, mapping commonly involves panning, pitting, soil auguring, and geophysical surveying. Ground magnetometer surveys clearly distinguish the boundaries of the kimberlite pipes as zones of high magnetic gradient around a central irregular magnetic high. The magnetically defined borders correspond to geologically determined contacts where exposures give sufficient control.

Xenocrysts (size $<1 \mathrm{~cm}$ ) and megacrysts $(>1 \mathrm{~cm})$, particularly of the indicator minerals Cr-rich pyrope, Cr-rich diopside, and Mg-rich ilmenite, provide information about both the presence of kimberlite pipes and their diamond potential. Pyrope megacrysts are conspicuous because of their large size and their red-orange color. $\mathrm{Cr}$ pyrope xenocrysts, because of their purple to red color, are the most conspicuous of the durable indicator minerals and are typically $0.5-5 \mathrm{~mm}$ in size. These garnets are chemically similar to garnets in garnet peridotite xenoliths in Montana kimberlites and thus are from disaggregated peridotites, indicating that the kimberlite has sampled depths in the upper mantle where diamond might be present. Most of the $\mathrm{Cr}$-rich, $\mathrm{Mg}$ - 
rich garnets from alluvium show a positive correlation of $\mathrm{CaO}$ and $\mathrm{Cr}_{2} \mathrm{O}_{3}$ that matches the band of $\mathrm{CaO}-\mathrm{Cr}_{2} \mathrm{O}_{3}$ compositions of garnets from lherzolites. Cr-rich, Ca-poor pyropes that are derived from Ca-poor garnet harzburgites are favorable indicators of diamond presence in kimberlites elsewhere in the world. We have not found garnets of markedly low $\mathrm{CaO}$ content in Montana or Michigan kimberlites, but we have found a few garnets that contain slightly less $\mathrm{CaO}$ than the lherzolite garnets and thus may be significant. Mg-rich ilmenites in both the Michigan and Montana kimberlites are in the compositional range favorable for diamond presence (high $\mathrm{MgO}$, moderate $\mathrm{Cr}_{2} \mathrm{O}_{3}$, and low $\mathrm{Fe}_{2} \mathrm{O}_{3}$ ).

Calculated temperatures and pressures for garnet peridotite xenoliths from Montana kimberlites and for eclogite xenoliths and composite peridotitic xenocrysts (Cr-rich pyrope plus Crdiopside) from the Michigan kimberlite range from the graphite stability field into the diamond stability field. Thus kimberlites of both areas have originated from or ascended through regions of the upper mantle where, if carbon were present and oxygen fugacity were low, diamond would be a stable phase.

Comparison of bulk chemical compositions of U.S. kimberlites using the discriminant function of Zhong Ruyuan (1983, Geochemistry, v. 2, p. 233-242) shows that Kentucky (diamondbarren) and Colorado (diamond-bearing) kimberlites are in the diamond-bearing range, Michigan kimberlite (diamond content unknown) and Arkansas lamproite (diamond-bearing) are in the overlap zone of diamond-bearing and diamond-barren kimberlites, and Montana kimberlite (diamondbarren) is in the diamond-barren range.

\section{COBALT-RICH FERROMANGANESE CRUSTS IN THE OCEANS}

\section{James R. Hein and Frank T. Manheim}

Ferromanganese crusts form on hard substrates in three general geotectonic environments: flanks of midplate seamounts, ridges, and plateaus (chiefly hydrogenous crusts); active oceanic spreading ridges (hydrothermal crusts); and convergent margins such as island arcs (combinations of hydrothermal and hydrogenous processes). Crusts commonly have botryoidal surfaces and laminar internal development on a continuous substrate or around isolated nuclei. Since the West German Midpac cruise of 1981, hydrogenous crusts have been recognized as potential offshore mineral resources owing to their valuable metal content. They are of special interest to the United States since many crust areas lie within the U.S. EEZ (Exclusive Economic Zone). The principal exploratory cruises devoted to crust investigations are listed in table 1.

$\mathrm{Be}^{10}$ and uranium-series radiometrically dated hydrogenous crusts have been shown to grow at

TABLE 1.-Principal exploratory cruises devoted to crust investigations

\begin{tabular}{c} 
Date Vessel \\
\hline July '81 --- Sonne - Sponsor
\end{tabular}


rates of about 1-3 mm/m.y., and their thickness commonly corresponds to the age of the substrate. Consequently, old oceanic features, like the Cretaceous Line Islands and Midpacific Mountains in the Pacific and New England Seamounts in the Atlantic, have the thickest crusts (as much as $11 \mathrm{~cm}$ ). Economically significant thicknesses of crusts (thicker than $2 \mathrm{~cm}$ ) have been found in many ocean areas, but the highest content of valuable metals has been found in the north equatorial parts of the Line Islands trend $(\mathrm{Co} \geq 1.2$ percent, $\mathrm{Mn}=25-34$ percent, $\mathrm{Ni}=0.4-0.6$ percent, $\mathrm{Pt}=$ 0.2-0.8 ppm); metal content varies inversely with water depth. Slightly lower values have been found in the Midpacific Mountains area, the northwestern Hawaiian Archipelago seamounts, and the Marshall Islands. Where iron contents are high $(\mathrm{Mg} / \mathrm{Fe}<1.0)$, as in the Tonga Ridge, cobalt and other valuable metals are lower $(\mathrm{Co}=0.36$ percent).

The Blake Plateau, off North and South Carolina, has large tonnages of low-grade ferromanganese oxides in water depths of 700-1,000 m, within the U.S. EEZ. The oxides form nodules, slabs, and hard pavements mixed with phosphorite and cover as much as $14,000 \mathrm{~km}^{2}$. Other documented or inferred crust provinces on the Atlantic margin are the easternmost part of the New England Seamounts, the Bahamas slope region, and old, exposed ridges in the Caribbean Sea (Aves Ridge and Beata Ridge).

\section{NEW SILVER RESOURCE MAP OF THE UNITED STATES-POTENTIAL FOR INCREASED DOMESTIC SILVER PRODUCTION}

\section{Allen V. Heyl and Robert B. Hall}

A new silver resource map of the United States was compiled in 1984 to replace the out-ofprint U.S. Geological Survey Map MR-34 published in 1962. Estimated past production (in troy ounces) plus estimated resources of each district are indicated on the new map by the size of the dot representing the district. The text includes brief summaries of mining history, geologic setting, and character of the ores for each district, an improvement over the one-line descriptions of districts that accompanied the 1962 map. Many locations have been added, especially in the Eastern United States.
Information gained during compilation of the new map suggests that domestic silver resources may be considerably greater than previously believed. The Eastern United States, particularly the Appalachian province from northern New England to Alabama, is a more promising source of silver and associated metals than generally is realized. Deposits mined during the 19 th century and even earlier, before the American Revolution, merit further investigation in areas where urban encroachment does not yet inhibit mining. The Western United States will continue to be the $\mathrm{Na}$ tion's principal source of newly mined silver, with the Coeur d'Alene region in Idaho likely to remain preeminent for the foreseeable future. Newly developed silver mines, such as the Escalante in Utah, the Troy in Montana, and others in Nevada, Idaho, and California, are expected to make an increasingly important contribution.

Silver and gold-silver mines are now the main sources of the country's silver. In the Southwest, output of byproduct silver from low-grade porphyry copper deposits has been reduced sharply in recent years because of production cutbacks resulting from low copper prices. Part of this lost silver production is being made up by revived operations in old Western mining districts. Some of these have been abandoned for nearly a century, but they contain veins and replacement deposits, which, although much smaller than the porphyry deposits, contain a much higher tenor of precious and base metals. Heap leaching of old dumps and tailings represents a temporary revival at some districts, but ultimately new ore must be mined if production is to be sustained. Some districts probably contain large resources of primary sulfide ores, which, although lower grade than the oxidized ores mined during the 19th and early 20th centuries, are amenable to modern processing techniques.

Numerous once-productive districts of the Western United States are located on the new map and described in the accompanying text. Most of the districts in the Eastern United States produced little silver, but several are believed to have significant potential. The revised silver resource map and text will be useful to industry in selecting new exploration targets for silver and associated metals. Factors that will influence future exploration and mining are (1) favorable metal prices, (2) funds available to finance exploration and establish mine plants and concentrators, (3) convenient- 


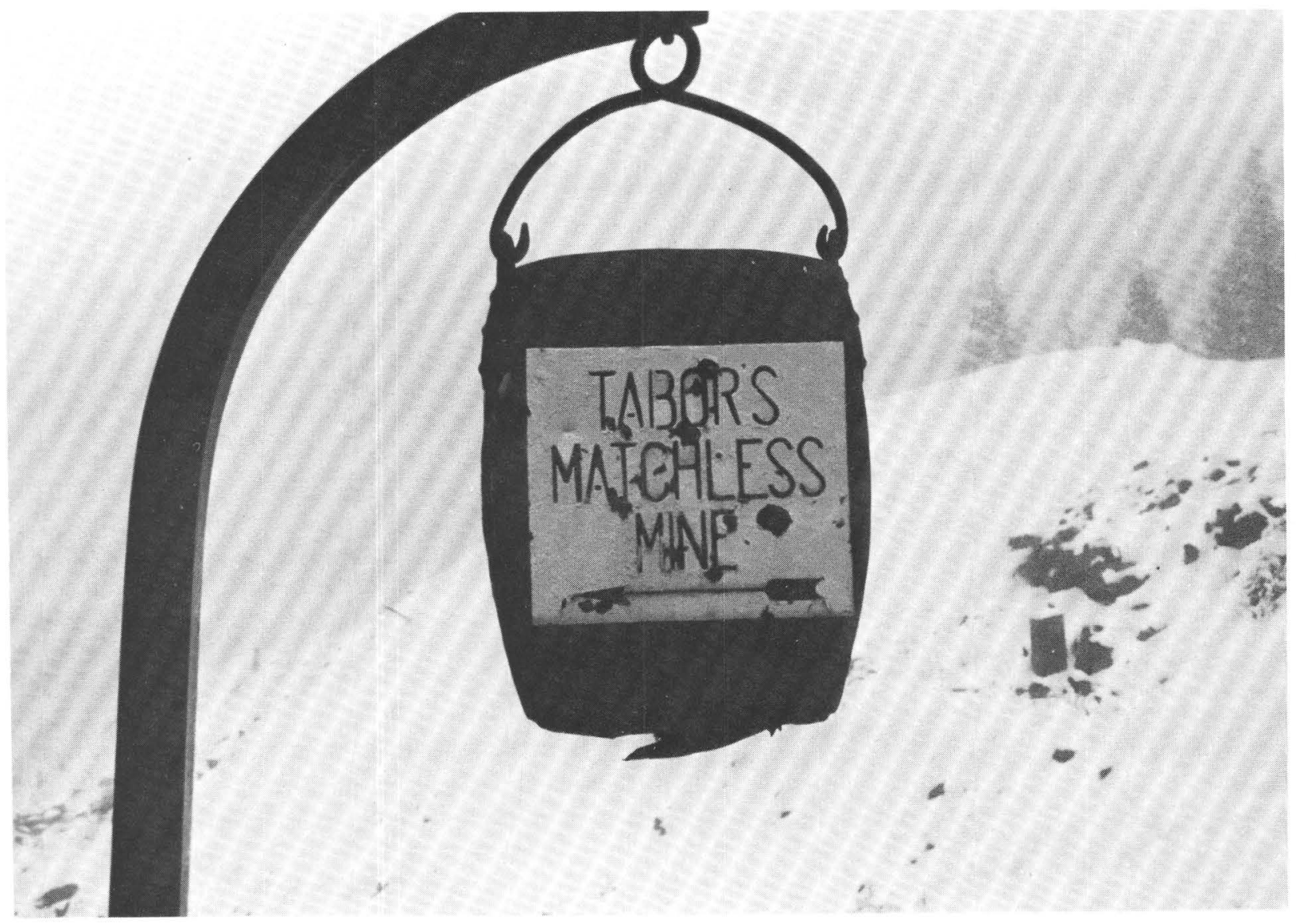

The famous Matchless silver mine, Leadville, Colorado

ly located smelters and refineries so that cost of shipping ores and concentrates is not prohibitive, and (4) favorable Federal and State policies.

\section{VOLATILE ELEMENTS AND COMPOUNDS IN EXPLORATION GEOCHEMISTRY}

\section{Margaret E. Hinkle and J. Howard McCarthy}

The use of gases in geochemical exploration is receiving increased attention as an exploration technique in the search for concealed mineral deposits. Volatile components of soil gases such as carbon dioxide, oxygen, sulfur compounds, hydrocarbons, and helium have delineated known ore deposits. The goal of volatile-element research in the Branch of Exploration Geochemistry is to develop the use of these constituents of soil gas in the search for concealed deposits.

Two methods are used to collect soil gas in the field. The first method consists of pounding a hollow probe into the ground and collecting a soil gas sample in a syringe by inserting the syringe needle through a cap in the probe and withdrawing the gas sample. This gas sample is analyzed without further treatment. The second method uses the soil itself as a collector of gases rising from below. Soils are placed in vials, which are sealed and then heated to drive off the gases. The gas in the vial (headspace gas) is analyzed.

Soil gas samples are analyzed in the field for constituents such as carbon dioxide, oxygen, and hydrocarbons by a truck-mounted quadrupole mass spectrometer. Analyses of soil gas samples collected by hollow probe and gas samples liberated from heated soil samples are performed in the laboratory. Analyses of gases such as carbon dioxide, oxygen, hydrocarbons, and sulfur compounds are performed by gas chromatography; helium is analyzed by a modified mass-spectrometer helium detector. 


\section{Recent Research Results}

Massive sulfide deposit, Wisconsin.-Soil gas anomalies were found over a massive sulfide deposit in northern Wisconsin through as much as $60 \mathrm{~m}$ of glacial deposits. Anomalous carbon dioxide contents were as high as 6 percent of the soil gas sample, and coincident but negative anomalous oxygen contents were as low as 9 percent of the soil gas sample. Hydrocarbon gases (alkanes) also coincided with the mineralization.

North Silver Bell porphyry copper deposit, Arizona.-Volatile elements and compounds were measured in gases derived from soil samples. Anomalous concentrations of helium (>10 ppm), carbon disulfide ( $>100 \mathrm{ppb}$ ), and sulfur dioxide (>300 ppb) were found adsorbed on soil samples taken over the ore body. Higher than normal concentrations of carbon dioxide ( $>0.25$ percent) and carbonyl sulfide ( $>300 \mathrm{ppb}$ ) were found adsorbed on soil samples taken over the alteration zones around the ore body.

Johnson Camp copper-zinc deposit, ArizonaSulfide ore bodies occur at depths ranging from 10 to $225 \mathrm{~m}$ at Johnson Camp. Above-average concentrations of carbon dioxide ( $>1.5$ percent) and helium ( $>5.5 \mathrm{ppm}$ ) were present in soil samples taken over all the ore bodies; high carbonyl sulfide (>600 ppb) and carbon disulfide (>60 ppb) contents were found in soil samples taken over ore bodies as deep as $150 \mathrm{~m}$. The occurrence of volatile elements and compounds related to ore bodies at these depths below the ground surface indicates that these volatiles could be valuable aids to geochemical exploration.

\section{ELECTRICAL GEOPHYSICAL STUDIES OF MASSIVE SULFIDE DEPOSITS AND THEIR HOST ROCKS, WEST SHASTA COPPER-ZINC DISTRICT}

\section{Robert Horton and Bruce D. Smith}

The West Shasta copper-zinc district, Shasta County, California, contains many volcanogenic sulfide deposits within Middle Devonian rhyolite volcanic rocks that have not been highly metamorphosed. The district was selected for intensive geological, geochemical, and geophysical study by the U.S. Geological Survey because good exposures have been created both by erosion and by mining. This report describes the galvanic and inductive electrical methods applied to characterize the large- and small-scale electrical geophysical properties of selected massive sulfide deposits and their host rocks. Electrical geophysical methods have long been used in exploration for massive sulfide deposits of Precambrian age, but little has been reported on electrical geophysical applications to younger, less metamorphosed deposits.

The electrical geophysical techniques used included galvanic (electrical currents introduced directly into the earth) and inductive methods (currents indirectly introduced). Inductive methods can locate the following conductive features: fault zones, hydrothermally altered bedrock, conductive shales, and massive sulfide deposits. Combined use of methods that have different depths of penetration can provide useful information about the geometry and depths of a conductor. A profile using very low frequency (VLF), slingram, and time-domain electromagnetic induction methods over a known tabular sulfide body at the Hornet Mine showed that all three can detect the shallow sulfide deposit. Part of a profile measured in the Keystone mine area is over a small block of shale that has been downfaulted into volcanic rock. Anomalies from the VLF survey in this area define the conductive nature of the fault zone, while deeper penetrating frequency and time-domain methods indicate that a separate conductor is also present.

Though inductive electromagnetic methods can define conductive features, they cannot identify the source, whether massive sulfide bodies, conductive formations or structures. In situ spectral induced polarization (SIP) measurements were carried out to electrically characterize massive sulfide bodies exposed at the Iron Mountain and Balaklala mines. In addition, in situ measurements were used to evaluate whether SIP measurements could provide additional information for classifying the source of electromagnetic anomalies. These in situ measurements defined the resistivity of these massive sulfide bodies to range from 5 to $0.05 \mathrm{ohm}$-meters. This range is similar to resistivities observed in Archean massive sulfide deposits. In situ SIP phase spectra (the IP effect as a function of frequency) have much less character and lack the distinctive shape reported for Canadian massive sulfide deposits. Additionally, the magnitude of the IP response is about 50 percent less than reported values of older 
massive sulfide deposits. We attribute the more nondescript spectral signature and lower IP response to the lack of development of polarization processes and a high percentage of nonpolarizable gangue minerals. However, a SIP profile over the Hornet massive sulfide body shows much better development of the spectral response. Interestingly, most of the Hornet ore body has been mined, leaving only a 2- to 3-m shell. The observed polarization response is therefore dominated by polarization of the ground water-sulfide contact, a polarization mechanism different from that observed during in situ measurements. The Hornet survey demonstrates that the electrical signature of a massive sulfide body differs from that of its host rock. The SIP survey on the Keystone profile suggests that part of the electromagnetic response is due to massive sulfides. Thus the source of electrical geophysical anomalies can be determined from their polarization signatures.

\section{MASSIVE SULFIDE DEPOSITS FROM THE SOUTHERN JUAN DE FUCA RIDGE}

Randolph A. Koski, David A. Clague, James L. Bischoff, and Robert A. Zierenberg

Six hydrothermal vent sites and associated benthic communities were located in the axial valley of the southern Juan de Fuca Ridge in 1981, by means of transponder-navigated bottom photography. The hydrothermal deposits form chimneys, spires, and mounds within a central zone characterized by a linear bathymetric depression and numerous collapse features. The flat valley floor adjacent to the central zone consists of ferrobasalt lobate sheetflows; sediment cover is minimal. Vent sites are characterized by concentrations of tube worms, clams, limpets, gastropods, and several unidentified fauna.

Two types of massive sulfide were dredged from one of the vent sites. Type A samples are angular slabs of dark-gray Zn-rich sulfide with interlayers and a thin, partly oxidized crust of $\mathrm{Fe}$ sulfide. The outer sulfide wall is composed mainly of colloform $\mathrm{Fe}$ sulfide and Fe-poor sphalerite deposited under lower temperature conditions whereby sea water and hydrothermal fluid mix above the discharge point. With continued sulfide deposition, the wall inhibits mixing of sea water and hydrothermal fluid. Inside the wall, the inten-

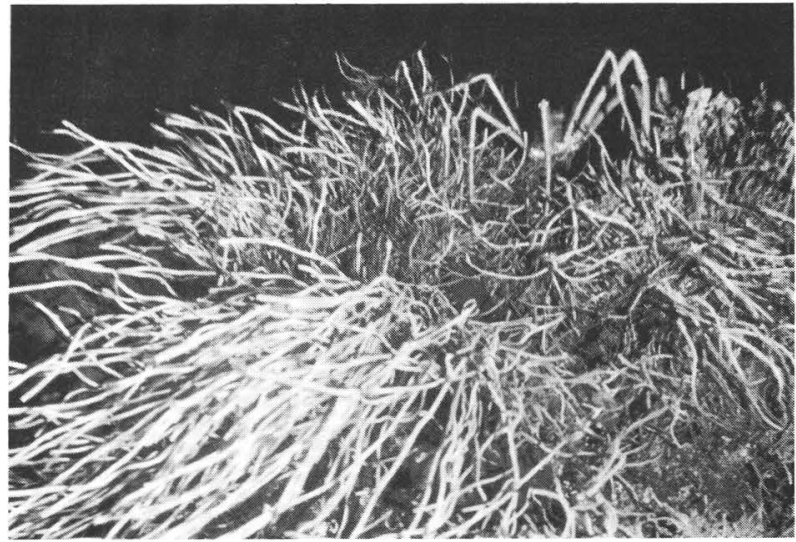

Tube worms and crab at low-temperature vent on southern Juan de Fuca Ridge

sifying hydrothermal system deposits a higher temperature assemblage of granular Fe-rich sphalerite, wurtzite, pyrite, and minor $\mathrm{Cu}-\mathrm{Fe}$ sulfide. The zonation in wurtzite from $\mathrm{Fe}$-rich cores to Fe-poor rims may result from a late-stage cooling of the hydrothermal fluid and (or) a change in fluid chemistry. The sulfide wall grows outward where a rupture in it permits the escape of hightemperature fluid and then deposition of a secondary shell over the breakthrough point. As temperature increases, earlier formed minerals dissolve, and $\mathrm{Zn}, \mathrm{Fe}$, and $\mathrm{Pb}$ migrate toward the outer sulfide wall. Tube worms flourished in the outer wall of type A samples, and abandoned tube structures served as conduits for the late-stage hydrothermal fluids.

Type B sulfide samples are subrounded, spongy-textured fragments composed almost entirely of dendritic aggregates of pale Fe-poor colloform sphalerite and opaline silica. This type of sulfide is deposited in open spaces by moderate- to low-temperature fluid discharging at a slow but variable rate; the fluid becomes increasingly oxidizing, resulting in late-stage deposition of hematite, barite, and sulfur. Type B samples show little evidence of burrowing animals. Active and inactive chimney samples recently collected by ALVIN are dominantly of type B sulfide. A single sample recovered in 1983 on the ANGUS camera sled is predominantly type B sulfide overprinted by late-stage type A mineralization. Additional dredged samples are coarse-grained sulfide with textures identical to those of recrystallized massive sulfide deposits.

The dredged Zn-rich samples have high bulk concentrations of the chalcophile elements Ag, As, 
$\mathrm{Cd}, \mathrm{Tl}$, and Ge; however, Au is less than $0.1 \mathrm{ppm}$ and Pt less than 0.005 ppm.

\section{GAS ANALYSIS OF ORE-FORMING FLUIDS}

\section{G.P. Landis}

Precise analysis of the volatiles or gaseous fluids trapped in fluid inclusions during mineralization is used to determine physical and chemical parameters of metal transport and deposition and to better understand the environments of ore formation. Knowledge of the abundance of such gases as $\mathrm{CO}_{2}, \mathrm{CH}_{4}, \mathrm{SO}_{2}, \mathrm{H}_{2} \mathrm{~S}, \mathrm{~N}_{2}, \mathrm{O}_{2}, \mathrm{NH}_{3}, \mathrm{Ar}, \mathrm{H}_{2}$, and $\mathrm{H}_{2} \mathrm{O}$ in mineralizing fluids enables us to significantly refine ore-genesis models. The new mass spectrometer instrumentation developed for these analyses will also permit isotopic analyses of both stable isotopes $(\mathrm{C}, \mathrm{O}, \mathrm{S}, \mathrm{H}, \mathrm{N})$ and radiogenic isotopes ( $\mathrm{Ar}, \mathrm{Ne}, \mathrm{Xe}, \mathrm{Kr}, \mathrm{He}$ ) for very small samples extracted from fluid inclusions.

Gas in fluid inclusions and other geologic materials is analyzed using a newly developed highperformance quadrupole mass spectrometer system, equipped with rods $30 \mathrm{~cm}$ in length by $1.6 \mathrm{~cm}$ in diameter, electromagnetically focused crossbeam ion source with dual iridium filaments, an off-axis electron multiplier (gain to $10^{8}$ )/faraday cup collector, and 16K-data-point digital oscilloscope. A mass charge $(\mathrm{m} / \mathrm{e})$ range of $1-255$ atomic mass units (AMU) is achieved, with at least unit resolution (10 percent valley), scan speeds of $100 \mathrm{~s}$ to $30 \mathrm{~s} / \mathrm{AMU}$, and a minimum detectable partial pressure of $8 \times 10^{-15}$ mbar ( $8 \mathrm{ppb}$ sensitivity). Instrument monitoring and control are completely computerized. FORTRAN- and MACRO-based software transfers data, makes computations, and produces tabulated analyses and graphical reports.

Gas samples are liberated from host minerals either by mechanical crushing or by thermal decrepitation. Inlet sample gas pressures (to 10 Torr) are monitored with a capacitance manometer, whereas the high vacuum attained by turbomolecular pumps $\left(<10^{-9}\right.$ Torr $)$ is measured with standard Bayard-Alpert gauges. Inlet design includes a low volume internal resistive heating coil for work on small samples. An Nd-YAG (yttrium aluminum garnet) laser coupled through a microscope is being developed to enable opening individual inclusions for analysis while the sample is po- sitioned in the mass spectrometer high-vacuum inlet. Other features of the instrument include cryopump traps and charcoal traps, $\mathrm{Zr}$-Al gettering alloys, a $\mathrm{CuO}$ finger, and an ion pump.

Special applications of the gas analysis system that are progressing along with the final stages of instrument development include (1) study of complex $\mathrm{H}_{2} \mathrm{O}-\mathrm{CO}_{2}-\mathrm{CH}_{4}-\mathrm{N}_{2}$-rich metamorphic fluids of upper greenschist facies rocks as possible ore-forming fluids in the Coeur d'Alene silver district, Idaho (with D.L. Leach), (2) evaluation of the importance of magmatic volatiles during comagmatic evolution and formation of Black Range (Taylor Creek) tin occurrences, New Mexico (with R.O. Rye and M.D. Wasserman), (3) assessment of the role of volatiles in the complex zonation and evolution of the Ta-bearing Harding pegmatite, northern New Mexico, (4) examination of organic components in the fluid inclusion gas from epigenetic sulfides in coal beds (with J.F. Whelan), and (5) development of data processing methods for quadrupole measurement of the carbon and oxygen isotope ratio of carbon dioxide fluid inclusions. By using appropriate collection procedures, inexpensive analytical methods for gas can be applied empirically to geochemical exploration for base- and precious-metal deposits.

\section{PRECIOUS AND BASE METAL MINERALIZATION IN THE COEUR D'ALENE DISTRICT, IDAHO, DURING PROTEROZOIC METAMORPHISM OF THE BELT BASIN}

\section{David L. Leach, G.P. Landis, and Albert H. Hofstra}

Silver and lead-zinc-copper veins in the Coeur d'Alene district in northern Idaho occur in the most intensely and complexly deformed parts of the Proterozoic Belt Supergroup rocks. The rocks were regionally metamorphosed to upper greenschist facies during the late Precambrian, and this metamorphism, coincident with intense structural deformation, produced the vein mineralization. The veins were pathways for the escape of large volumes of metamorphic fluid and are believed to have formed along sites of hydraulic fracture or dilation of pre-existing fractures when fluid pressure exceeded load pressure.

The ore is older than and clearly unrelated to the Gem stocks of Cretaceous age for the following reasons: (1) Coeur d'Alene veins do not cut the 
stocks but instead are sheared into them; (2) sulfide zoning is not present in veins about the stocks; (3) parts of veins within the contact aureole of the Gem stocks contain metamorphic garnet and biotite and recrystallized sulfide textures not observed outside the aureole; (4) Gem stocks are "dry" intrusions that have sharp contacts with Belt rocks, lack miarolitic cavities or pegmatitic textures, and lack abundant hydrous minerals and hydrothermal alteration; and (5) lead isotopes from the ore are radiogenic Precambrian lead, distinctly different from lead of the Cretaceous intrusions.

Fluid-inclusion studies provide strong evidence that vein mineralization was produced by greenschist metamorphic fluids. These studies indicate that the temperature of the mineralizing fluid was about $350^{\circ} \mathrm{C}$, the pressure was more than 1-2 kbar, and the salinity was 5-10 weight percent. Fluid compositions are dominated by $\mathrm{H}_{2} \mathrm{O}, \mathrm{CO}_{2}, \mathrm{CH}_{4}, \mathrm{~N}_{2}$, and $\mathrm{NaCl}$. Some fluid inclusions rich in $\mathrm{CO}_{2}, \mathrm{~N}_{2}$, or $\mathrm{CH}_{4}$ are believed to have trapped immiscible fluids present in the veins under metamorphic conditions. In addition to these components, other volatiles in the ore fluid represent refractory compounds of nitrogen and light-chain hydrocarbons that include alkenes, aliphatic nitriles, and primary amides. Water present in the fluid inclusions is highly radiogenic and has variable strontium isotopic compositions (initial ${ }^{87} \mathrm{Sr} /{ }^{86} \mathrm{Sr}$ of $>1.000$ to 1.420 ) that are characteristic of unhomogenized, greenschist-grade metamorphic fluids.

Other evidence also supports the concept of mineralization by metamorphic fluids. (1) Veins occur along brittle fractures developed during major deformation of the rocks. (2) Veins having a vertical extent of as much as 8,000 feet do not show strong T-P gradients or mineral zones. (3) Extensive areas of hydrothermally altered rocks did not form. (4) Numerous veins of similar mineralogic and geologic character occur over a wide area in the region and yield similar fluid-inclusion $T-P-X$ data. (5) Analysis of a coarse-grained sericite from a mineralized vein yielded a $\mathrm{K}$-Ar age of $829 \mathrm{Ma}$, approximately coincident with the isotopic age for deformation, metamorphism, and uraninite vein mineralization. (6) The range in $\delta^{34} \mathrm{~S}$ of probable sulfur source(s) in the host rocks is approximately -6 to +18 per mil, whereas that in vein sulfides reflects a narrower range indicative of sulfur isotope homogenization in the metamorphic fluid.

The distribution of mineralization was con- trolled initially by stratigraphic permeability, producing disseminated replacement mineralization; later, when fracture permeability dominated the fluid flow dynamics, ore minerals were localized in major fractures or veins. Mechanisms for mineral deposition include changes in $\mathrm{pH}, \mathrm{fO}_{2}$, and other chemical parameters of the ore fluid by loss of volatiles, immiscibility in the $\mathrm{H}_{2} \mathrm{O}-\mathrm{CO}_{2}-\mathrm{NaCl}$ system, and $\mathrm{CO}_{2}-\mathrm{CH}_{4}-\mathrm{H}_{2}$ equilibria.

\section{PARTIAL CHEMICAL EXTRACTIONS-THEIR APPLICATION TO GEOCHEMICAL EXPLORATION FOR ORE DEPOSITS IN THE TROPICAL ENVIRONMENT}

\author{
Robert E. Learned, T.T. Chao, and \\ Richard F. Sanzolone
}

The objectives of our investigations were to determine the mode in which ore-related metals are bound in geochemical sample media of mineral districts of the tropical environment and the best use of that information in geochemical exploration. Accordingly, we applied partial chemical extraction procedures to determine the distribution of trace metals among the mineralogic and chemical phases that constitute several geochemical sample media of two porphyry copper districts in Puerto Rico.

In saprolite, soil, and stream sediment of the districts, the secondary iron oxide phases bear the highest proportion of ore-related metals; silicate, sulfide, and organic phases bear substantially lower proportions. Moreover, the secondary oxide phases provide significantly stronger geochemical contrasts (anomaly-to-background ratios) than do other phases or the bulk media. Only in unweathered rock (drill core) of the deposits is the sulfide phase an important bearer of ore-related elements. Distinctive patterns of apportionment of trace metals among phases thus characterize particular geochemical sample media of the district, and such patterns reflect the intensity of the chemical processes that attended the formation of respective media.

Partial chemical extraction procedures demonstrably have significant application to both the orientation and interpretive stages of geochemical exploration for metallic deposits in the tropical environment. 


\section{METALS IN PLANTS-EXPLORATION OF THE RED MOUNTAIN GOLD-BEARING STOCKWORK, YELLOW PINE DISTRICT, IDAHO}

\section{B.F. Leonard, J.A. Erdman, and D.M. McKown}

New exploration targets for gold, molybdenum, tungsten, and tin are indicated by the systematic distribution of metals in soil and plants of the Red Mountain stockwork and its environs. The stockwork is built of countless quartz veins and veinlets, is extensively argillized, and contains sparsely disseminated gold, pyrite, arsenopyrite, pyrrhotite, fluorite, and other minerals. The stockwork developed along the outer ring-fracture zone of the Eocene Quartz Creek cauldron where subsidence strain, unrelieved by radial faulting, produced internal deformation and intense smallscale fracturing in rocks of the Idaho batholith. The stockwork crops out as a fault-bounded polygon $2,700 \mathrm{ft}(820 \mathrm{~m})$ long and $2,000 \mathrm{ft}(600 \mathrm{~m})$ wide. It contains (underlies?) a large, virtually barren quartz body $1,350 \mathrm{ft}(410 \mathrm{~m})$ long and $350 \mathrm{ft}$ $(100 \mathrm{~m})$ wide. Deformed and shattered granite flanks and presumably underlies the stockwork, which may plunge southward beneath inclusionbearing granodiorite and alaskite of the Idaho batholith suite. Narrow dikes of rhyolite and latite radiate from two centers within the quartz body. Many dikes and small bosses of rhyolite and latite intrude stockwork and granite. The radial habit of some dikes and the high concentration of small intrusions within alteration zones of sericite and kaolinite suggest that a Tertiary porphyry is concealed beneath the mountain. Clay-mineral alteration zones mapped in residual soil extend far outward from the stockwork. Valleys filled with Quaternary deposits conceal the stockworkgranite complex on the east, north, and west.

Metal anomalies in soil of a gridded area $3,600 \mathrm{ft}(1,100 \mathrm{~m})$ by $8,400 \mathrm{ft}(2,600 \mathrm{~m})$ are mostly weak and small. In contrast, metal anomalies in plants are strong and large. Gold in ashed sapwood of Douglas-fir (Pseudotsuga menziesii) indicates a major $\mathrm{Au}$ anomaly, peak value $14.2 \mathrm{ppm}$, associated with granodiorite in an unexplored area south of the exposed stockwork. Locally, the Au anomaly is accompanied by a sizable tin anomaly, peak value 100 ppm, in Douglas-fir. Molybdenum concentrations in ashed leaf samples of beargrass (Xerophyllum tenax) indicate an extensive anoma- ly within a 2-mi-long (5-km-long) semielliptical belt in which Mo values exceed the median value, $20 \mathrm{ppm}$. The maximum Mo concentration is $500 \mathrm{ppm}$. Most of the belt occurs on valley fill, but the southern segment of it, near the major $\mathrm{Au}$ anomaly, is underlain mainly by granodiorite. Here, where beargrass is sparse, the peak value of Mo in beargrass drops to $70 \mathrm{ppm}$. Where beargrass is absent, ashed leaves of sedge (Carex geyeri) were used; these samples contain up to 100 ppm Mo. An additional target for Mo is indicated by molybdenite from the inaccessible part of a prospect adit. The molybdenite, seen only in dump specimens, is in weakly silicified granite that may underlie part of the stockwork. The source of the molybdenite is hidden, and it is not indicated by geochemical data for samples of soil or plants. Just north of the major Au anomaly, in an area of float containing disseminated scheelite in weakly silicified granodiorite, 2-ppm values of $\mathrm{W}$ in beargrass coincide with a W anomaly in soil (peak value $22 \mathrm{ppm}$ ). Other areas characterized by $2 \mathrm{ppm}$ $\mathrm{W}$ in beargrass are nearly coextensive with the Mo-in-beargrass anomalies that overlie Quaternary deposits of Quartz Creek valley. Some of the target areas for $\mathrm{Au}, \mathrm{Mo}, \mathrm{W}$, and $\mathrm{Sn}$ have not been circumscribed by our sampling. The results suggest the presence of a concealed elliptical substructure that may be hoodlike and may contain more than one mineralized zone.

\section{MINERAL DEPOSIT MODELS- THEORY AND PRACTICE}

\section{Steve Ludington and Paul Barton}

By the authority of the Organic Act of 1879 , the USGS has the responsibility for "classification of the public lands and examination of the... mineral resources and products of the national domain." A vital tool used to fulfill this responsibility is the mineral deposit model. We define a model here as systematically arranged information that describes the essential attributes of a complex process or product.

The uses of models may be classified as follows: (1) guidance of land-use planning, (2) estimation of potential commodity supplies or endowment, (3) support of prospecting, (4) education, and (5) guidance of research. 
Models may be grouped into subtypes such as (1) descriptive, (2) genetic, (3) probability-ofoccurrence, (4) grade/tonnage, and (5) quantitative process. Descriptive models together constitute a deposit classification and are a prerequisite for other types. Alone, they are most useful for research guidance and prospecting. Genetic models link the characteristics of descriptive models to underlying geologic processes and, because they are predictive, are extremely powerful for prospecting, as well as for education and research guidance. Probability-of-occurrence models result when numerical measures of importance are attached to descriptive characteristics in order to provide a numerical estimate of mineral potential. Implementation of these is in its infancy, but clearly they will be most useful for land planning and resource estimation. Grade/tonnage models use compilations of grade and tonnage information and allow assignments of probable value to be made. They are most useful for resource estimation and land-use planning. Quantitative process models result from the quantitative study of phenomena such as mass and energy transfer, and, at present, are used chiefly for research guidance and education.

The generality of the USGS mandate results in a different approach from that of most other model users. In mineral exploration, for example, activity might progress from the identification of a commodity to selection of appropriate models, followed by their application to the goal of identifying new deposits. In contrast, the programs of the USGS approach models from a geographic context. Collection of geologic information precedes model selection. For example, in support of landuse planning, we are concerned with all commodities, and we build from the observations relating to a tract of land to a determination of mineral potential. Single attributes, such as "Secondary biotite is present," are generally ambiguous, although they may well suggest what additional observations might be made. Combinations of attributes are used to identify specific models, and new combinations may lead to new models. We are working to smooth and, where appropriate, to automate that identification.

Fulfillment of our mission has two distinct parts: appropriate information about the earth must be generated and must be communicated to the public. The model effort promises to be a powerful contributor to both science and society.

\section{EARLY AND MIDDLE CENOZOIC VOLCANIC SYNTHESIS}

\author{
Robert G. Luedke
}

Maps for the middle and early Cenozoic volcanic centers (16-55 $\mathrm{Ma}$ ) in the western conterminous United States are now being compiled in a manner similar to a series of seven maps showing the distribution, composition, and age of late Cenozoic volcanic centers $(0-16 \mathrm{Ma})$ in the Western United States, Alaska, and Hawaii, which are published or in the process of publication (USGS Miscellaneous Investigations Series Maps I-1091). Those maps portray vent types, locations, and ages and major rock types and ages in the volcanic centers at the scale of $1: 1,000,000$; special larger scale maps show specific areas. That map series was designed primarily as a guide for exploration and evaluation of igneous-related geothermal resources but also serves as a base for evaluation of volcanic hazards and for studies of evolution of magmatic systems, related ore deposits, and general geology of volcanic rocks.

For the new map series, most of the basic data have been accumulated for the Arizona-New Mexico-west Texas area; future work will cover all the conterminous Western States, within which a large number of the known mineral deposits are closely associated with or related to igneous centers. The rocks in these centers are being depicted in selected major rock compositions within arbitrarily established silica increments, in three age categories within the $16-55 \mathrm{Ma}$ time frame, and as extrusive or intrusive types. The distribution of these volcanic-intrusive centers in the Western United States is known, but the quality and quantity of data varies. Also, the existing data are not on a map at a single scale and do not permit distinguishing the igneous rocks in a uniform manner throughout the region.

Analysis of the temporal and spatial relations among igneous rock types, their tectonic relations, and their relation to ore deposits is fundamental to present and future progress in research on ore deposition, tectonism, and magmatism. Synthesis of the geological and geochemical data illustrated on this new series of maps will be used to produce models that will guide exploration for ore deposits and improve resource assessment. 


\section{EXPERT SYSTEMS RESEARCH IN REGIONAL RESOURCE EVALUATION: EXPERIENCES IN THE APPLICATION OF MICROCOMPUTER TECHNOLOGIES}

\section{Richard B. McCammon}

muPROSPECTOR, patterned after SRI's expert system PROSPECTOR, is designed to aid the geologist in evaluating the mineral resources within a given geographic area. The central idea of the system is matching deposit models encoded by expert economic geologists against observations made by field geologists. muPROSPECTOR is a microcomputer-based system that can be applied to problems in regional mineral resource evaluation. To date, the knowledge base that has been incorporated in muPROSPECTOR consists of deposit models constructed as part of the mineral resource assessment in the Sherbrooke-Lewiston $1^{\circ} \times 2^{\circ}$ quadrangles in New England. Included are models for volcanogenic massive sulfide, sediment-hosted lead-zinc-silver, tin greisen, porphyry copper, vein-type uranium, uraniferous peat, and tin-placer deposits. These models are represented in the knowledge base as a set of rules derived from recognition criteria developed for each deposit type.

In a normal consultation with muPROSPECTOR, the geologist is asked a series of questions relating to various pieces of evidence that might be present in an area. Answers to these questions lead muPROSPECTOR to an evaluation of the mineral resources in the area. The evaluation consists of a probabilistic estimate for one or more deposits occurring in the area for each of the deposit types being considered and the reasons upon which the evaluation for each deposit type is based. At any time during the consultation, the geologist can ask muPROSPECTOR to summarize and make an evaluation based on the current information. The intent of the system is to provide the geologist with services equivalent to telephone access to a panel of experienced economic geologists, each an authority on a particular type of deposit.

Experience with muPROSPECTOR has indicated that improvements in designing future expert systems for regional resource evaluation are needed in knowledge representation, reasoning mechanisms, and knowledge acquisition. Current limitations in knowledge representation are the result of insufficient expressiveness of the language used to encode deposit models. Insufficient general knowledge of the geology of most of the models that have been constructed is also a major problem. What is needed are methods for matching observations volunteered by geologists about the general geologic, geochemical, and geophysical setting in an area with the attributes of existing models. With respect to reasoning mechanisms, control strategies are needed that take into account the more or less imperceptible grading of the characteristics of one deposit type into those of other deposit types. Current control strategies make restrictive assumptions about the interdependency of multiple sources of evidence and the manner in which they combine. With respect to knowledge acquisition, methods are needed for screening of data bases compiled for ore deposits, formulation of less-than-perfect models that others can subsequently modify easily, and computer-assisted instruction in deposit modeling. Future developments in muPROSPECTOR will require a close working relationship with economic and field geologists.

\section{APPLICATIONS OF THE MINERAL RESOURCES DATA SYSTEM AND THE INTERNATIONAL. STRATEGIC MINERALS INVENTORY IN MINERAL-RESOURCE ASSESSMENTS BY REGION AND COMMODITY}

\section{Antoinette L. Medlin, David M. Sutphin, and John H. DeYoung, Jr.}

From 1972 to 1982 , the USGS developed the Computerized Resources Information Bank (CRIB). CRIB, a centralized data base, was initiated to meet the growing need for rapid access to data on mineral deposits and occurrences. Regional and commodity information was collected from geologists and commodity specialists at the USGS, other Federal agencies, and State geological agencies. In 1982, CRIB was used as the basis for establishing the Mineral Resources Data System (MRDS), which applies computerized data to mineral-resource assessments.

MRDS contributes to several current USGS programs, including the Federal Mineral Land Information System (FMLIS), the Conterminous United States Mineral Assessment Program (CUSMAP), and the Alaska Mineral Resource Assessment Program (AMRAP). Data from 
MRDS are merged with digital boundary files in the FMLIS program to define areas with estimated potential for mineral resources. Effects of proposed land withdrawal and other existing or proposed limitations on mineral development can be graphically analyzed for selected areas. MRDS is a repository for data derived from CUSMAP and AMRAP studies and, when a new CUSMAP or AMRAP quadrangle is started, as a source of data for analysis to eliminate duplication of effort.

MRDS includes the capability of storing data on mineral deposits and occurrences for use in deposit-type studies. Geodetically located information can be plotted in relation to digital data for area geology maps, regional terrane maps, geopolitical boundary maps, and other map bases that have been digitally recorded. Foreign and domestic data can be analyzed regionally and on a commodity basis in relation to known or suspected geologic features.

One of the goals of the MRDS is to have data coverage by area and commodity for the major domestic and foreign deposits. One method to expand and improve the data for commodities was to use the existing cooperation with personnel involved in resource analysis in Canada and Germany. Initial planning sessions with members of earth-science and mineral-resource agencies in the United States, Canada, and Germany, and later South Africa, Australia, and the United Kingdom, led to the establishment of the International Strategic Minerals Inventory (ISMI) in November 1981 to gather, analyze, and present information on major deposits of selected strategic mineral commodities. A basic premise is that, for many commodities, much of the current and near-future production is and will be from the few largest deposits. A data collection form for ISMI was designed and guidelines for data collection established. Participating countries agreed to a prototype phase of data collection with manganese, chromium, phosphate, and nickel as the subjects of initial study. In October 1983, work started on six additional commodities; these commodities and the country assigned as chief compiler are titanium-Australia, tungsten-Canada, graphite-Germany, vanadium-South Africa, cobalt-United Kingdom, and the platinum-group elements-United States. ISMI products include published circulars and data sets, including expert opinions on major deposits, which are a part of MRDS.

\section{FISSION-TRACK DATING APPLIED TO MINERAL EXPLORATION}

\section{C.W. Naeser and Charles G. Cunningham}

Fission tracks are cylindrical zones of intense ionic disruption, which are formed in uraniumbearing solids by the passage of highly charged nuclei from the spontaneous fission of ${ }^{238} \mathrm{U}$. Once formed, these tracks are stable in most minerals at temperatures less than about $80^{\circ} \mathrm{C}$. If the mineral is heated above a critical temperature, the tracks will disappear (anneal) as a function of time and temperature. For periods of geological time, the critical temperature for apatite is $120 \pm 20^{\circ} \mathrm{C}$; for zircon, it is $200 \pm 30^{\circ} \mathrm{C}$. Upon cooling these minerals will again begin to accumulate fission tracks.

The partial to total resetting of fission-track ages of apatite and zircon in country rock around a mineralized area can be used to (1) locate a paleothermal anomaly, (2) determine the age of a paleothermal anomaly that may coincide with a mineralizing event, and (3) determine the direction toward the heat source. Two mining districts in Colorado have been studied, Rico and Gilman.

Rico is a precious- and base-metal mining district. Sedimentary rocks throughout the district were intruded at $65 \mathrm{Ma}$ by hornblende latite porphyry sills. Initial fission-track dating of a sill located about $6 \mathrm{~km}$ from the center of the district gave a reset age of $20 \mathrm{Ma}$ for apatite and the age of intrusion of $65 \mathrm{Ma}$ for zircon. Subsequent sampling and dating of sills closer to the mineralized area indicated the presence of a roughly concentric paleothermal anomaly with an age of about $5 \mathrm{Ma}$ centered east of town. We interpret this to indicate the location of a large, unexposed, rhyolite stock of Pliocene age; the mineralization was caused by this stock, rather than by events associated with the intrusion of the Late Cretaceous monzonite stock exposed at the surface just west of the town.

The ore body of the Eagle Mine, in the Gilman district, occurs as a manto deposit of sulfides that was deposited in a Paleozoic karst cave system in the Leadville Dolomite. Fragments of the Pando Porphyry (about $70 \mathrm{Ma}$ ) found in the cave floor breccia are surrounded by a sulfide-bearing matrix, indicating the age of the ore body must be younger than Late Cretaceous. A paleothermal anomaly defined by fission-track dating of apatite 


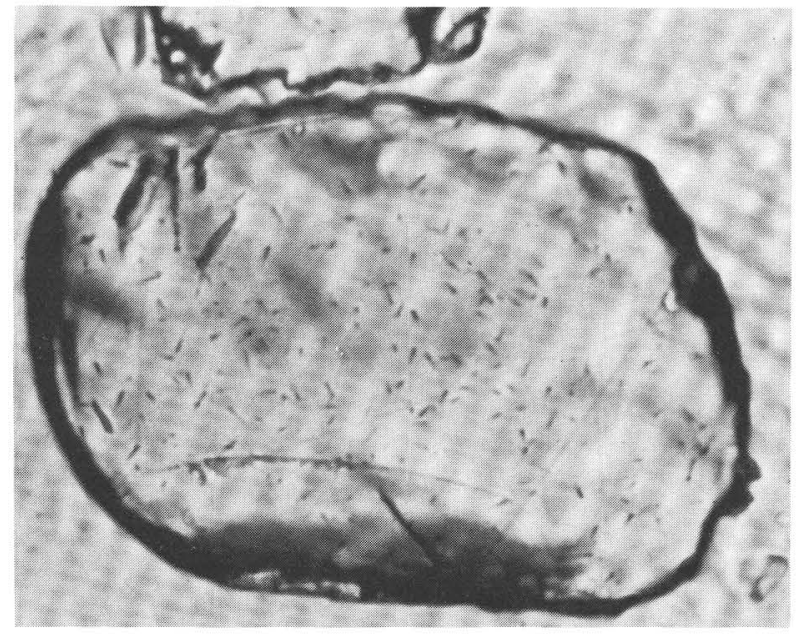

Fission tracks in apatite; large crystal is about $0.25 \mathrm{~mm}$ across

and zircon circumscribes the ore body at the Eagle Mine, even though virtually no alteration of the country rock adjacent to the deposit is observed.

Fission-track ages of apatite and zircon were determined for samples of the Pando Porphyry (present throughout the district), of the Precambrian rocks in the Eagle River Canyon $180 \mathrm{~m}$ below the ore body, and of Precambrian rocks sampled from cores drilled directly beneath the ore body. Apatite from a vug filling in the ore body was also dated. Preliminary stable-isotope and fluid-inclusion data suggest that the ore deposit was formed at temperatures in excess of $300^{\circ} \mathrm{C}$, well above the fission-track annealing temperature for both apatite and zircon. The fission-track results indicate that the age of the thermal anomaly is about $34 \mathrm{Ma}$ and that a major paleothermal anomaly extends more than $1.5 \mathrm{~km}$ from the deposit. Zircon from the Pando Porphyry $0.5 \mathrm{~km}$ north of the Eagle Mine and apatite from the ore body have ages of $34.0 \pm 1.5 \mathrm{Ma}$ and $34.5 \pm$ 2.6 Ma, respectively. Zircon from the Pando Porphyry $1.5 \mathrm{~km}$ north of the Eagle Mine yields an age of about $45 \mathrm{Ma}$, indicating only partial resetting of the age by the thermal event that is associated spatially with the ore deposit. None of the ages from the Precambrian rocks below the deposit have been significantly reset. These data suggest that the source of the thermal anomaly was not directly beneath the deposit.

\section{A MULTIDISCIPLINARY RESOURCE ASSESSMENT OF THE CHUGACH NATIONAL FOREST, ALASKA}

\section{Steven W. Nelson}

The Chugach National Forest, a 9,000-mi ${ }^{2}$ $\left(23,000-\mathrm{km}^{2}\right)$ area, is the second largest national forest in the United States and the largest national forest evaluated under the National Forest Wilderness Act. A multidisciplinary resource assessment was conducted between 1979 and 1982. The largely reconnaissance-scale study by the U.S. Geological Survey included geologic mapping; regional aeromagnetic and gravity surveys; stream-sediment, panned-concentrate, bedrock, and organic-geochemistry studies (for hydrocarbons); and stable-isotope geochemistry and fluidinclusion studies of specific mineral deposits. Concurrently, the U.S. Bureau of Mines conducted mapping and geochemical and mineralogical studies of mines, prospects, and mineral occurrences. From these studies, 25 resource areas were identified. To facilitate land-planning decisions, these areas have been ranked, from most favorable to least favorable, for potential for additional resources of those commodities ( $\mathrm{Au}, \mathrm{Cu}$, oil, coal) with a history of production in the study area.

The geology of the national forest is dominated by two major lithologic units, the Late Cretaceous Valdez Group and the Paleocene and (or) Eocene Orca Group. Both groups, separated by the Contact fault system, consist largely of metamorphosed to unmetamorphosed graywacke, siltstone, and shale. The Orca Group has traditionally been considered to be somewhat less metamorphosed than the Valdez Group and to be further distinguished from it by the presence of mafic volcanic rocks and local beds of conglomerate. Our mapping, however, has shown that these rock types are found in both groups. Sedimentary rocks, in part younger than the Orca Group, crop out in the southeastern part of the project area. Plutonic rocks were emplaced in Eocene and Oligocene time. Most of the plutons are granitic in composition, but an early phase of the Oligocene plutons ranges in composition from quartz diorite to gabbro.

Previous studies ${ }^{7}$ have suggested that the

${ }^{T}$ Tysdal, R.G., and Case, J.E., 1982, Metalliferous mineral resource potential of the Seward and Blying Sound quadrangles, southern Alaska: U.S. Geological Survey Miscellaneous Field Studies Map MF-880-H, scale 1:250,000. 


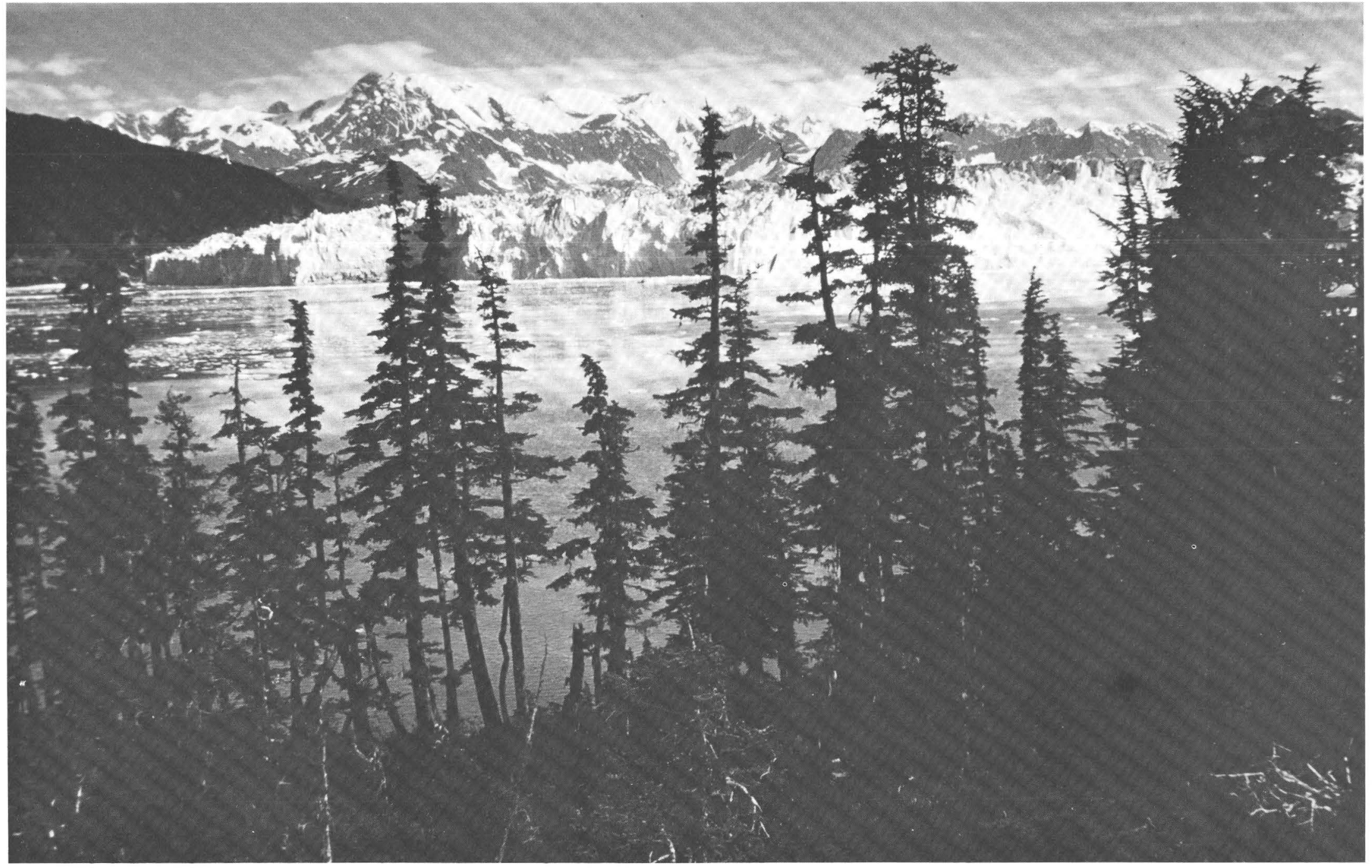

Columbia Glacier entering Prince William Sound (tidewater), Chugach National Forest, and Chugach Mountains, southern Alaska 
Valdez and Orca Groups represent two different metallic mineral provinces. The Valdez Group is characterized by deposits worked for gold and the Orca Group by deposits worked for copper. This distinction is weakened by our study, which shows that the copper deposits appear to be related to mafic volcanism and are generally found in, or spatially related to, mafic volcanic rocks in both the Valdez and Orca Groups and that the goldbearing deposits occur in quartz fissure veins apparently hosted by various rock units. Gold, for example, is found in quartz veins that have been dated at $53 \mathrm{Ma}$, which cut Valdez Group sedimentary rocks, and in quartz veins cutting $34-\mathrm{Ma}$ plutons. In these occurrences, the gold-bearing quartz veins occur along fractures and shears that cut across regional structure and fabric. Stableisotope studies suggest, at least for the older veins, that hot meteoric water leached the gold from the country rock. In the Orca Group, gold occurrences are restricted to quartz veins cutting sedimentary rocks near the 51-Ma McKinley Lake pluton and to quartz veins cutting greenstone in a few small areas.

An estimated 264,000 oz. of gold have been recovered, from both lode and placer sources. During a 30-year period beginning in the 1900's, nearly $206,400,000 \mathrm{lb}$. of copper, with minor amounts of gold and silver, were produced. Most of the ore was produced from four mines, though small amounts of copper were mined from at least 17 other operations. The placer gold deposits are principally confined to the Kenai Peninsula area, although other occurrences have been identified in almost all of the metal-bearing resource potential areas.

Extensive coal deposits occur in structurally complex Tertiary rocks in the Bering River area, and large tonnages of minable coal appear to be present. A total of about 20,000 tons of coal was produced intermittently in the early 1900's. The Katalla area has substantiated potential for oil and gas. The production of the field over a 30-year period was relatively small $(154,000 \mathrm{bbl})$, and the complex structure and lack of suitable reservoir rocks in the area suggest that major fields are unlikely.

\section{METALLOGENETIC HISTORY \\ OF THE WRANGELLIA TERRANE, EASTERN ALASKA RANGE, ALASKA}

\section{Warren J. Nokleberg and lan M. Lange}

Much of the southern part of the eastern Alaska Range, in the Mt. Hayes, Gulkana, and Nabesna quadrangles, consists of the Wrangellia terrane, which exhibits a long and complicated stratigraphic and structural history and a long and complicated metallogenetic history. In the eastern Alaska Range, Wrangellia consists mainly of (1) a thick sequence of late Paleozoic island arc rocks, including submarine andesite flows, breccias, epiclastic rocks, volcanic graywacke, argillite, marble, and altered andesite and dacite porphyries, disconformably overlain by (2) Middle to Late Triassic Nikolai Greenstone, intruded by (3) cumulate mafic and ultramafic rocks probably comagmatic with the basalt flows of the Nikolai Greenstone, and disconformably overlain by (4) Late Triassic limestone. These and other terranes are unconformably overlain by Late Jurassic and Early Cretaceous flysch and intruded by isolated plutons of probable Late Jurassic and Early Cretaceous age. The Wrangellia terrane exhibits upper greenschist facies metamorphism with a weak cleavage or schistosity.

Six principal types of mineral deposits and occurrences are found in Wrangellia in the eastern Alaska Range: (1) Small areas of sulfides, up to a few meters wide, with anomalous concentrations of $\mathrm{Cu}, \mathrm{Pb}, \mathrm{Zn}, \mathrm{Ag}$, and $\mathrm{Au}$, occur in fracture zones and are disseminated in hydrothermally altered late Paleozoic volcanic rocks. Common sulfide minerals are chalcopyrite, bornite, sphalerite, and pyrite. (2) Pods and lenses of massive sulfides and skarn deposits containing chalcopyrite and pyrite with anomalous concentrations of $\mathrm{Cu}, \mathrm{Ag}$, and $\mathrm{Au}$ occur in marble and in hydrothermally altered volcanic rock adjacent to Permian andesite and dacite porphyries. Maximum dimensions are a few meters. (3) Local disseminated sulfides with anomalous concentrations of $\mathrm{Cu}, \mathrm{Pb}, \mathrm{Zn}$, and $\mathrm{Ag}$ occur in hypabyssal Permian andesite and dacite porphyries. These porphyries are often propy- 


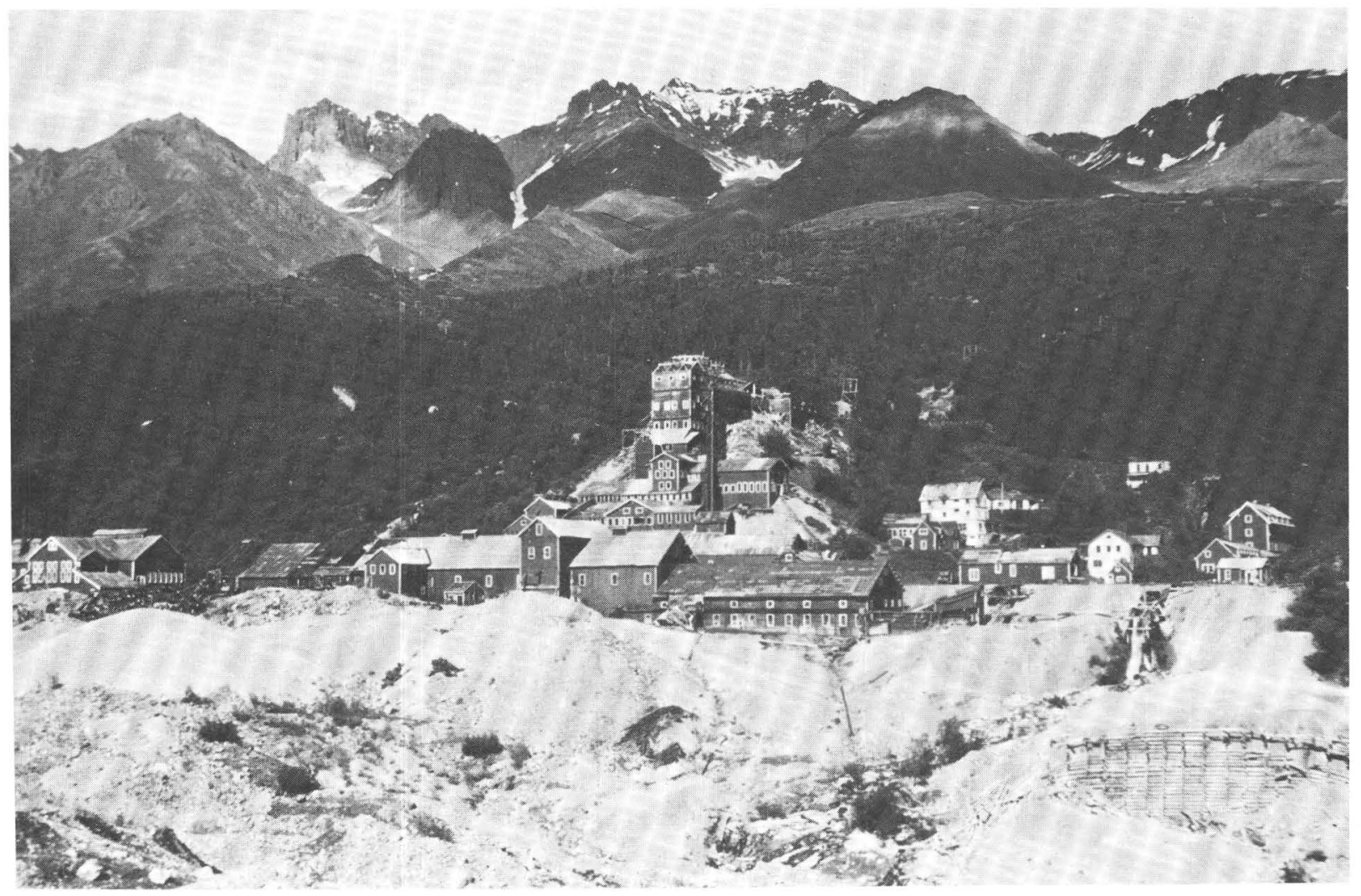

Kennecott mill and tailings at base of Bonanza Ridge, Wrangell Mountains, southern Alaska

litically altered, contain calcite and chalcopyrite veinlets, and are laced with disseminated chalcopyrite and pyrite. (4) Disseminated grains and lenses of Ni-bearing chromite occur in layers in cumulate mafic and ultramafic rock in extensive sills. (5) Disseminated sulfides with anomalous concentrations of $\mathrm{Cu}, \mathrm{Ag}$, and $\mathrm{Au}$ occur in various granitic plutonic rocks. These granitic rocks commonly contain very fine grained K-feldspar, quartz, secondary sericite, and pyrite, and minor chalcopyrite in fractures and isolated grains. (6) Sulfides with anomalous concentrations of $\mathrm{Cu}, \mathrm{Ag}$, and $\mathrm{Au}$ occur in quartz veins and associated altered Nikolai Greenstone and older metavolcanic rocks. The common sulfides are chalcopyrite, bornite, and pyrite.
Our preliminary accretionary terrane model relates the origin of these mineral deposits to the origin, migration, and accretion of Wrangellia. Initially, subduction formed a late Paleozoic island arc. During the early stages of the arc, disseminated and vein sulfide deposits formed in volcanic flows and associated rocks. Later, during the final stages of the island arc, sulfide deposits formed in skarn and volcanic rocks adjacent to shallow porphyries. Subsequent rifting during the Middle and Late Triassic resulted in submarine and subaerial extrusion of the Nikolai Greenstone and emplacement of associated cumulate mafic and ultramafic rock containing disseminated grains and lenses of chromite. In the Late Jurassic through Late Cretaceous, subduction and formation of an island arc 
along the leading edge of Wrangellia occurred during migration towards North America. This resulted in intrusion of plutonic rocks containing disseminated and vein base-metal sulfides and in local skarn formation adjacent to granitic plutons. Finally, Wrangellia was accreted onto the western margin of North America during the middle or Late Cretaceous, resulting in regional greenschist facies metamorphism and deformation that culminated in formation of late-stage quartz sweat veins and altered areas with $\mathrm{Cu}-, \mathrm{Ag}^{-}$, and $\mathrm{Au}-$ bearing sulfides. This model may be an important predictive tool for mineral resource assessment and for discovery of new mineral deposits in Wrangellia throughout the North American Cordillera.

\section{SEDIMENT-HOSTED ORE DEPOSITS: GENETIC PROCESSES INFERRED FROM THE MINERALOGIC, CHEMICAL, AND ISOTOPIC COMPOSITION OF CLAY MINERALS}

\section{H. Roy Northrop and Gene Whitney}

The characterization of mineralogic, chemical, and isotopic compositions of authigenic clay minerals enables recognition of the influence of sedimentary-basin-derived fluids on the genesis of sediment-hosted ore deposits. A case in point is the vanadium-uranium deposits hosted by the Morrison Formation (Upper Jurassic) in the Henry structural basin, Utah. There, an abrupt upper boundary and diffuse lower boundary of the vanadium-uranium mineralized interval occurs within an otherwise homogeneous sandstone body. The clay assemblage changes from authigenic kaolinite and smectite in barren rocks to vanadium-rich chlorite in the mineralized interval. The oxygen and deuterium isotopic compositions of these phases reflect the effects of a densitystabilized fluid interface between isotopically heavy brine (probably evolved from seawater) and isotopically light meteoric water. Isotope data indicate that vanadium-rich chlorite, the predominant vanadium-ore mineral in the deposits, formed at and below this interface within the saline fluid. This vanadium chlorite grades into a vanadiumbearing mixed-layer chlorite-smectite in the unmineralized lateral extensions of the deposits, reflecting the planar geometry of the ore-forming environment.

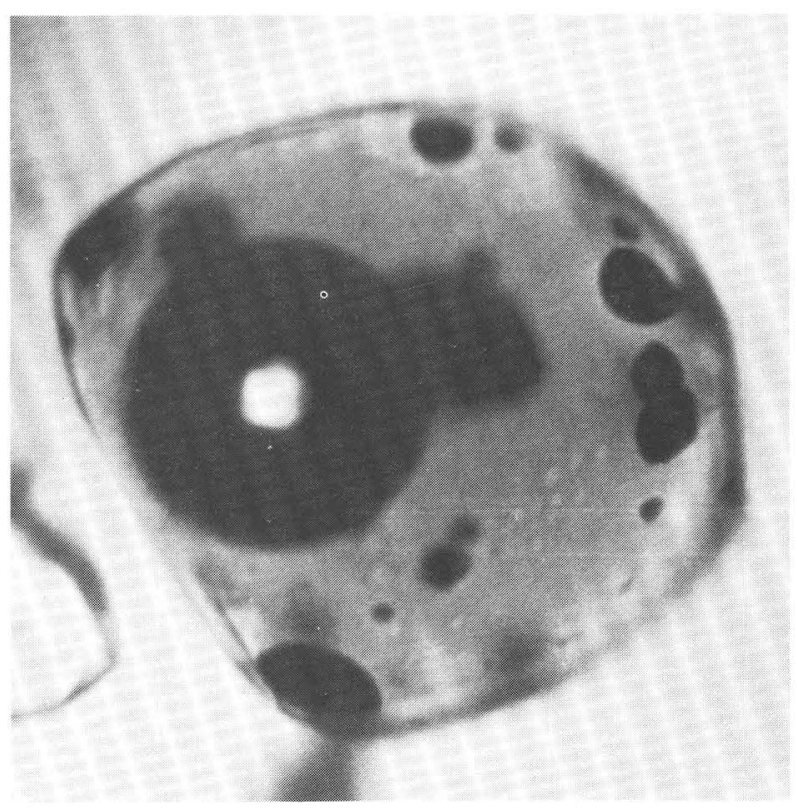

Organic-matter-rich fluid inclusion in fluorite, Cave-in-Rock, Illinois

A similar solution interface may have existed at the time of uranium mineralization in the 100-m-thick sandstone sequence of the Westwater Canyon Member of the Morrison Formation in the San Juan Basin, New Mexico. However, after ore deposition, fluid migrations driven by basin subsidence have geochemically altered and redistributed some of the uranium deposits. One such alteration, involving the updip migration of warm $\left(130^{\circ} \mathrm{C}\right)$ fluid from deeper in the basin, is defined by a systematic spatial zonation of neoformed chlorite and transformed illite-smectite within the Westwater sandstone. The proportion of illite in the mixed-layer illite-smectite is known to be related to potassium uptake, which is a function of temperature, time, and availability of potassium. The proportion of illite layers in the illite-smectite increases both toward the center of the sandstone, perpendicular to bedding, and downdip toward the basin center, parallel to bedding, as does the abundance of pore-filling chlorite. The oxygen and hydrogen isotopic compositions of the illitesmectite vary as a function of the degree of illitization and of position within the basin, whereas the isotopic composition of the authigenic chlorite remains uniform. At $130^{\circ} \mathrm{C}$ and in a porous sandstone medium, the apparent limit on the illitization reaction responsible for the mineralogic zonation is the aqueous potassium content of the 
migrating fluid. The calculated isotopic composition of the illitizing fluid, and its apparently limited potassium content, are consistent with the chemistry of "oilfield brines" described in several midcontinent basins. The broad interest in petroleum occurrences and Mississippi Valley-type base-metal deposits, both of which have inferred genetic links to the migration of these evolved basin waters, attests to the importance of this type of geochemical reconstruction.

\section{ORGANIC MATTER ASSOCIATED WITH METAL ORES OF HYDROTHERMAL VENT ORIGIN}

\author{
William H. Orem, Patrick G. Hatcher, \\ and Elliott C. Spiker
}

The recently discovered active submarine hydrothermal systems associated with marine spreading centers are living laboratories for studies of metal ore genesis. Massive sulfides, apparently similar to those associated with ophiolites found on land, are currently being deposited around these hydrothermal systems. In addition, communities of large benthic siphonophores have been observed clustered about these submarine hydrothermal vents. The primary producers for these communities are apparently chemoautotrophic bacteria, which derive energy from catalyzing the oxidation of reduced sulfur species emanating from hydrothermal vents. Results of preliminary studies also indicate the presence of large amounts of particulate and dissolved organic matter associated with the high biological productivity around these vents.

Organic matter may play a key role in the transport and deposition of metals in the deep sea. In the case of ferromanganese oxide deposits, organic matter adsorbed onto active surfaces (such as basalts) may initiate the deposition of manganese (IV) oxides. In addition, organic matter adsorbed on the surfaces of metal oxide and sulfide deposits may inhibit their dissolution and oxidation, respectively. Organic-matter-metal-ion complexes may also facilitate transport of various metal ions to sites of metal oxide or sulfide deposition for incorporation in these deposits.

We present here the results of a study on organic matter associated with massive sulfide deposits of known and presumed hydrothermal origin. The organic carbon contents of these ores ranged from about 0.01 percent to nearly 4.0 percent. In these samples, higher carbon contents were associated with pyritic and chalcopyritic ores, while sphalerite-rich ores had much lower carbon contents. For example, a massive pyrite ore from the Galapagos spreading center contained 3.0 percent organic carbon. The organic matter in this ore had a stable carbon isotope $\left(\delta^{13} \mathrm{C}\right)$ value of -27.4 percent and a stable nitrogen isotope $\left(\delta^{15} \mathrm{~N}\right)$ value of +2.1 percent. These values are very distinctive compared to deep-ocean sedimentary organic matter but are similar to values observed in benthic organisms associated with active submarine hydrothermal vents. The molar $\mathrm{C} / \mathrm{N}$ ratio of this sample (13.2) suggests a bacterial source for the organic matter associated with this metal ore. Solid-state ${ }^{13} \mathrm{C}$ nuclear magnetic resonance (NMR) spectrum of the organic matter associated with the metal ore from the Galapagos spreading center has a predominantly paraffinic character, with a small aliphatic C-O (that is, carbohydrate or ether) content and minor carboxyl or amide character. A small resonance due to aromatic carbon atoms was also observed in the spectrum. This spectrum resembled ${ }^{13} \mathrm{C}$ NMR spectra of refractory organic matter isolated from Holocene marine sediments whose source is predominantly algal or microbial. The absence of a strong aliphatic C-O and carboxyl or amide resonance in the spectrum suggests that the organic matter has been degraded by microbes during early diagenesis.

The organic matter in these ores appears to be derived from chemoautotrophic bacterial production surrounding the vents. As the massive sulfide deposits form, the organic matter is incorporated in the matrix of the ore. Such high concentrations within the ore may play a key role in retarding oxidation of the metal sulfides.

\section{SEDIMENT DISPERSAL PATTERN IN THE \\ EMERGED ATLANTIC COASTAL PLAIN \\ (NEW JERSEY-GEORGIA) FROM \\ EARLY CRETACEOUS TO HOLOCENE: \\ A GUIDE TO POTENTIAL PLACER DEPOSITS}

\section{James P. Owens}

Major depositional systems have been defined within the lithostratigraphic framework of the emerged Atlantic Coastal Plain. In general, delta and shelf deposits dominated before the Miocene; 
in the Neogene and Quaternary, barrier and backbarrier facies dominated. Grade and distribution of placer and other types of mineral deposits in the Atlantic Coastal Plain are controlled largely by these depositional systems.

Placer deposits in the Coastal Plain are characterized by heavy minerals derived from igneous and metamorphic rocks. The most common opaque minerals are ilmenite and its weathering products. Magnetite, the other common iron oxide, is present in major concentrations only in upper Pleistocene and Holocene beds even though it is a major opaque mineral in the Piedmont rocks adjacent to the Coastal Plain. The most common nonopaque minerals are zircon, tourmaline, and rutile (ZTR); hornblende, epidote, and garnet (plus actinolite and tremolite, HEGAT); and staurolite, sillimanite, and kyanite (SSK). Chloritoid, monazite, and igneous apatite are locally abundant. Numerous other minerals are present, but these occur only in minor to trace amounts and are economically unimportant.

Immature mineral assemblages are characterized by easily alterable non-opaques (HEGAT) and relatively fresh ilmenite and magnetite; mature mineral assemblages dominantly contain hard, chemically impervious non-opaques (ZTR) and weathered, iron-poor ilmenite. Maturity of placer mineral assemblages is a product of the mineralogy of the source rocks and the amount of physical and chemical alteration during and after deposition. The degree of maturity is thus linked to the depositional facies and the amount of time the sediment has remained in the emerged, actively oxidizing part of the Coastal Plain.

One example of the relationship of environment and maturity is the commercial concentration of ilmenite found in barrier facies of Florida and New Jersey. In both regions, ilmenite is most abundant in the oldest barrier systems in the region and is associated with a limited non-opaque assemblage (ZTR dominant). In the younger barrier systems in both regions, the concentration of ilmenite decreases as the proportion of HEGAT minerals increases, hence reflecting a decrease in maturity. Whether this relationship is a function of differences in the source rocks or a reflection of time of residence in outcrop is still uncertain.

Another example of the relationship of mineral concentration to depositional environment is the distribution of igneous phosphates, mainly monazite and less commonly apatite. Both min- erals are locally widespread in upper-delta-plain facies of the basal units of the Coastal Plain (Cretaceous), especially near the Fall Line. Apparently these minerals do not survive long transport or passage through the high-energy, nearshore marine environments because of their relative softness. Search for these minerals in potentially economic placers should be restricted to nonmarine, updip facies of the Coastal Plain.

In the emerged Coastal Plain, stratigraphic units of the same age (time slices) have characteristic heavy-mineral assemblages, which can guide shallow subsurface investigation for economic placers.

\section{STUDIES OF ORE DEPOSITS IN THE EARLY MAGMATIC ENVIRONMENT: THE STILLWATER COMPLEX, MONTANA}

Norman J Page, W.J. Bawiec, R.J. Blakely, G.K. Czamanske, L.J. Drew, Michael P. Foose, R.L. Helz, M.D. Kleinkopf, Bruce R. Lipin, Patricia J. Loferski, J.H. Schuenemeyer, and M.L. Zientek

The Stillwater Complex is a large Precambrian layered stratiform intrusion that crops out on the northern edge of the Beartooth Mountains in southwestern Montana and, as interpreted from geophysical studies, extends northward beneath the surface. A cooperative project composed of government, industry, and academic geoscientists has been investigating the Stillwater, in order to develop a detailed understanding of the genesis of the magmatic ore deposits it contains. The 2.7 to $3.1 \mathrm{Ga}$ intrusion is divided into three major stratigraphic units, each of which has its own characteristic mineralization: the Basal series, with disseminated to massive $\mathrm{Cu}-\mathrm{Ni}$-Fe sulfides; the Ultramafic series, with stratiform chromite deposits; and the Banded series, with platinumgroup elements (PGE) hosted in disseminated sulfide zones.

Within the Basal series, detailed mineralogic and geochemical studies indicate that $\mathrm{Fe}-\mathrm{Cu}-\mathrm{Ni}$ sulfides result from intrusion of magma saturated with sulfide at the time of intrusion. This interpretation is supported by the presence of sulfiderich dikes of mafic norites. Sulfur isotopic and lithologic studies do not suggest contamination or 


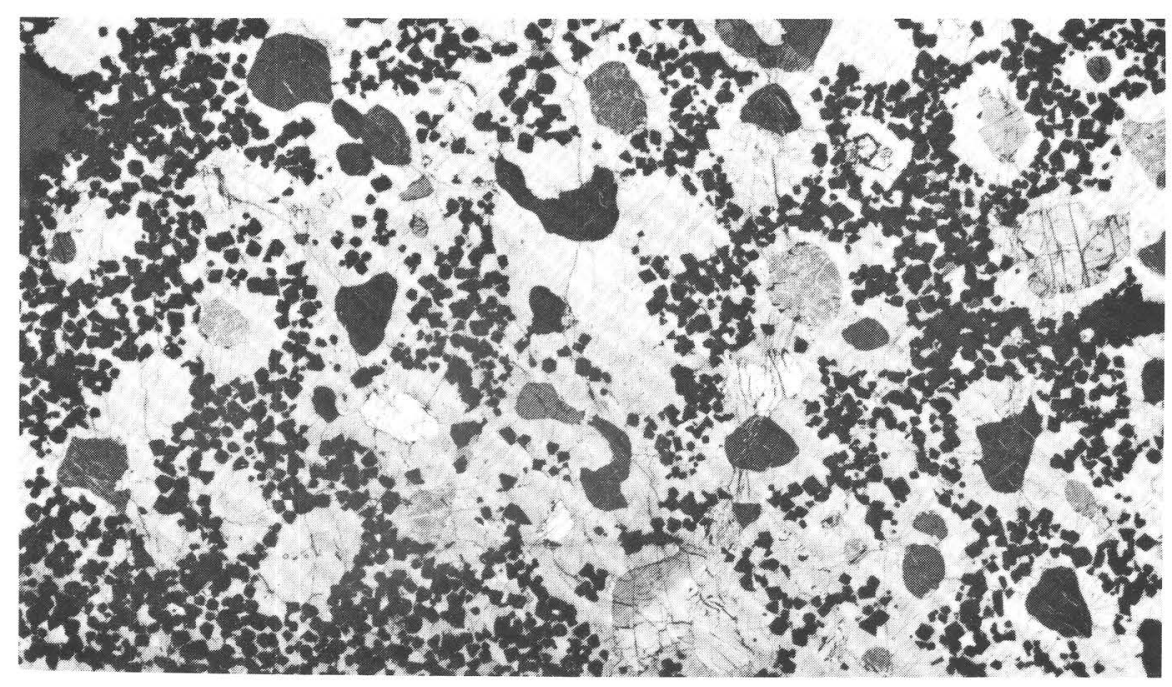

Photomicrograph of reaction replacement texture in poikilitic chromite-olivine cumulate, Ultramafic zone, Stillwater Complex, Montana

sulfur assimilation as the formative mechanism for these deposits. Cu-Ni concentration data and discriminant analysis can be used to map concentration units correlative with petrologicstratigraphic units. Investigations focused on the sills and dikes associated with the Basal series suggest that most of the fine-grained igneous rocks, previously interpreted to represent parental magma(s) of the complex, do not have compositions that could generate the rocks in the complex. Sills and dikes of gabbro-noritic composition with some textures apparently derived from rapid cooling occur immediately below the Basal series and are the most probable representatives of the parent magma of the complex.

Within the Ultramafic series, detailed field, mineralogic, and geochemical studies focused on the chromite seams and the associated cumulates. Pegmatoids containing pyroxene, plagioclase, and lesser amounts of olivine, chromite, and biotite are closely associated with the chromite seams and may be above, below, or within the seam. These pegmatoids are commonly irregular and patchy and not everywhere stratiform, but they are always stratabound. This suggests a genetic relationship between chromite seams and the devel- opment of pegmatoids; pressure fluctuations may explain the origin of chromite seams.

Within the Banded series, structural studies of sedimentary-like features and mineralogic and geochemical studies, particularly above and below the J-M Reef, have helped to unravel this complex series of rocks. Specifically, studies of structures including slumps, ramps, basins, and on-lap and off-lap of modal layers can be used to identify the larger primary basins in the Banded series that appear to be responsible for thickening and thinning of the mineralized zones. Recognition of mappable unconformities, combined with mineral composition and assemblage data, suggests successive additions of new magma to the Stillwater chamber. The hypothesis for origin of the platinumgroup element zones involves both features of sedimentary-like accumulating piles of crystals and interrelated changes in the chemical and physical properties of the parent magmas.

The major types of mineralization exhibit similarities in mineralogy, chemistry, and structures; however, there are many differences in enrichment of metals, in their distribution, and in the relative importance of chemical and physical processes that may have produced the deposits. 


\section{RECENT STUDIES OF THE DISTRIBUTION OF BACILLUS CEREUS NEAR SUBSURFACE GOLD DEPOSITS}

\section{Nancy L. Parduhn, John R. Watterson, and Miles L. Silberman}

Results of several soil surveys in the vicinity of subsurface gold deposits show that an aerobic spore-forming soil bacterium, Bacillus cereus, often occurs in greater numbers or as a greater percentage of the Bacillus population in soils overlying mineralized bedrock than in adjacent, unmineralized terrain.

In Clear Creek County, Colorado, the distribution of $B$. cereus was studied in ten $\mathrm{O} 1$ and $\mathrm{A} 1$ soil horizon samples overlying gold veins. The veins are covered by $3-5 \mathrm{~m}$ of glacial overburden. $B$. cereus culture counts from both soil horizons are at least an order of magnitude higher in soils over the gold veins than in immediately adjacent soils. In a previous USGS study of soil geochemistry in this district, A1 soil horizons were found to be a far less effective sampling medium than $\mathrm{O} 1$ soil horizons (mull) for outlining gold veins in bedrock beneath the cover of glacial drift. The $B$. cereus assay appears equally effective in both soil horizons.

Near Redding, California, soil traverses show elevated numbers of $B$. cereus displaced downslope from two greenstone-hosted gold veins, one exposed and one covered by $7-10 \mathrm{~m}$ of soil. Background counts of $B$. cereus in immediately adjacent soils are nil ( $<10 \mathrm{~B}$. cereus/gram).

Soils collected over the Hog Ranch disseminated gold deposit, located on the flank of a rhyolite flow-dome structure in Washoe County, Nevada, contain $B$. cereus populations one to two orders of magnitude higher than in adjacent unmineralized soils.

Soils as much as several kilometers from the Dee disseminated gold deposit near Carlin, Nevada, contain large numbers of $B$. cereus, and it is not clear at present if these large numbers are associated with mineralization. However, among 290 soil samples taken over the present pit area and in adjacent soils up to $8 \mathrm{~km}$ from the Dee deposit, the highest value $(1,570,000 B$. cereus/gram) occurred in a cluster of high samples (all $>100,000 /$ gram) in soils developed on barren rock $100 \mathrm{~m}$ above the deposit.

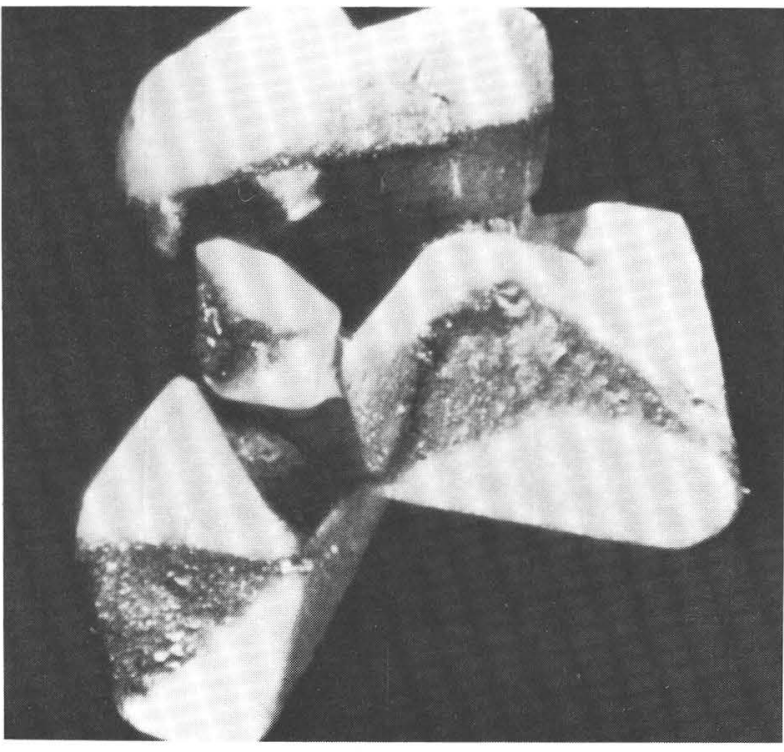

Gold crystals from a California placer; possibly nucleated around bacteria

Soil samples from three other gold deposits have recently been collected and assayed: a Carlintype disseminated gold deposit, a disseminated gold deposit hosted in metamorphic rocks, and a disseminated gold breccia-pipe deposit, all covered by pediment. A relationship can be seen between $B$. cereus distributions and the location of mineralization in each case.

Earlier studies of penicillin resistance in soil bacteria over two copper deposits indicated that $B$. cereus might thrive over many mineral deposits. Recent work indicates that the ability of $B$. cereus to resist antibiotics produced by metaltolerant fungi gives $B$. cereus an advantage in metalliferous soils. Studies of several different mineral deposit types that occur in a variety of lithologic and climatic settings indicate that the phenomenon is general and may have broad applicability in geochemical exploration.

The $B$. cereus assay has several advantages over conventional geochemical analysis: (1) $B$. cereus distributions are effective in glacial or pediment-covered terrain where geochemical techniques are of limited value. (2) The test is extremely rapid and inexpensive. On average, 50-60 samples a day can be processed. (3) Reproducibility of the technique is good (relative standard deviation $=10$ percent). 
A COMPARISON OF LANDSAT THEMATIC MAPPER, MULTISPECTRAL SCANNER, AND AIRBORNE SENSORS FOR MAPPING THE DISTRIBUTION OF ALTERATION MINERALS: EXAMPLES FROM THE SOUTHWESTERN UNITED STATES

\section{M.H. Podwysocki, M.S. Power, O.D. Jones,} M.H. Koslow, and William E. Collins ${ }^{8}$

Spaceborne geologic remote-sensing capabilities have progressed over the years from the relatively simple four-channel Landsat Multispectral Scanner (MSS), which operates in the visible and near-infrared region and is capable of few mineralogic distinctions, to the present sevenchannel Landsat Thematic Mapper (TM), which has additional channels in the near- and midinfrared regions, allowing further mineralogic distinctions. Airborne spectroradiometers, precursors to future spaceborne systems, contain 64 or more narrow channels that can be used to identify individual species in some mineral groups. Data from these instruments were compared to determine their effectiveness for mapping hydrothermally altered rocks in Nevada and Utah study areas. These areas contain old mining districts noted for their past production of precious metals; the Nevada area is undergoing exploration for these and porphyry-type base-metal deposits.

Hydrothermally altered volcanic rocks, which are indicators of potential mineralization, commonly contain such ferric-iron-bearing (limonitic) minerals as hematite, goethite, lepidocrocite, and jarosite. These minerals exhibit characteristic broad absorption bands in the visible and nearinfrared part of the electromagnetic spectrum that are detectable using either the MSS or TM sensors. However, limonite may form by processes unrelated to alteration. Hence, sole use of a limonite criterion in mapping alteration patterns may lead to inclusion of unaltered rocks. Conversely, bleached altered rocks lacking limonite will be excluded.

Hydrothermally altered volcanic rocks also commonly contain minerals that have the hydroxyl anion bound in their lattice structures. These minerals, such as clays, micas, and hydrated sulfate minerals, exhibit narrow and often diagnostic absorption bands in the near-infrared part of the spectrum covered by TM.

${ }^{8}$ Columbia University, New York, N.Y.
A comparison of band ratio images for the MSS and TM data shows significant differences in discrimination of altered from unaltered rocks. The MSS images depict most of the limonitic, hydrothermally altered rocks, on the basis of the characteristic signatures of limonite. However, the images also include many unaltered tuffs and plutonic rocks that display a limonitic signature. Also, dark sericitically altered volcanic rocks are not distinguished. Because of the additional bands in the near-infrared region, TM data can be used to distinguish limonitic unaltered from altered volcanic rocks and white unaltered from bleached argillized volcanic rocks. Also, dark sericitized volcanic rocks display a distinctive signature on the TM band ratio images.

Airborne spectroradiometer data collected over another area were used to distinguish individual mineral species within the altered areas, on the basis of diagnostic absorption bands in the near-infrared part of the spectrum. Minerals distinguished in the study area include kaolinite, alunite, jarosite, gypsum, a mixed-layer clay, and some mixtures of these minerals.

The progressive evolution of visible and nearinfrared sensor systems has provided the economic geologist with more detailed spectral information for a mineral exploration program. Anticipated results from airborne and spaceborne systems of the future suggest an even greater ability to distinguish mineral species.

\section{METAL CONCENTRATIONS IN MARINE BLACK SHALES}

\section{Forrest G. Poole and George A. Desborough}

We have been studying metal concentrations in marine black shales of several Paleozoic rock units in the Ouachita orogen of west-central Arkansas, west Texas, and central Sonora (Mexico); the Antler and younger orogens of central and northern Nevada, central Idaho, and northeastern Washington; the Sevier orogen of southeastern Idaho and adjacent States; and the cratonic Big Snowy trough of central Montana. Most metals are indigenous in shales with a thermal history of $<100^{\circ} \mathrm{C}$ but are redistributed in shales with a thermal history of $>200^{\circ} \mathrm{C}$. Our studies include general mineralogy, concentration of metals, 
alteration by ground water and weathering, types of associated strata, and types and thermal maturity of organic matter. Initial studies have emphasized the potential for metal and hydrocarbon resources in low-temperature $\left(<50^{\circ} \mathrm{C}\right)$ organic-matter-rich anoxic mudstone deposits in order to establish the syngenetic concentration and residence of metals in sapropelic sediments. Low-temperature mudstones studied include parts of the Ordovician Vinini Formation and Devonian Woodruff Formation of central and northern Nevada, Mississippian Heath Formation of central Montana, and Permian Phosphoria Formation of southeastern Idaho and adjacent States. Beds range in thickness from a few centimeters to several meters, and some of the thicker beds have been correlated throughout the region. Most of these metalliferous kerogen-rich shales have not previously been thoroughly examined for resources because rapid weathering and poor exposures preclude easy sampling of unoxidized rock, which is necessary to determine concentration and residence of indigenous metals.

Shales with the highest organic-carbon (algalkerogen) content usually contain the highest concentrations of several metals, including silver, vanadium, zinc, chromium, nickel, and molybdenum. In areas of low-temperature thermal history, algal kerogen-rich beds commonly are oil shales. We have been concerned specifically with shales that (1) contain $>10$ weight percent organic carbon and (2) have certain valuable metals, such as vanadium, molybdenum, nickel, and zinc, which have relatively high solubilities in seawater but were not derived from nearby hydrothermal or volcanogenic sources. In the Western United States, many low-temperature kerogenous marine black shales that exceed 10 weight percent organic carbon contain as much as $5,000 \mathrm{ppm}$ vanadium, $5,000 \mathrm{ppm}$ molybdenum, $1,300 \mathrm{ppm}$ nickel, 600 ppm cobalt, 20 ppm silver, 11,700 ppm chromium, $18,800 \mathrm{ppm}$ zinc, $280 \mathrm{ppm}$ cadmium, and $350 \mathrm{ppm}$ selenium. Microscopic, electron microprobe, and X-ray diffraction studies of unaltered samples indicate that the principal residence of vanadium, molybdenum, and selenium is in organic matter; nickel is principally in marcasite and pyrite; chromium is in organic matter, mica, and iron sulfide minerals; and zinc and cadmium are in sphalerite.

Post-depositional modifications such as diagenesis, elevated rock temperature, oxidation, and fluid movement cause redistribution (enrichment or depletion) of indigenous metals both within the shale units and across unit boundaries. An important redistribution and concentration process may be episodic sediment dewatering and expulsion of geopressured metalliferous and petroliferous (including methane-bearing) warm brines from deeply buried basinal black shales. This pore-fluid expulsion could result in upward migration of metal- and hydrocarbon-bearing ore fluids through conduits into shallow basin-margin sedimenthosted repositories (for example, Mississippi Valley-type lead-zinc deposits).

The total quantity of metals contained in black-shale deposits is enormous. Consideration of the usual parameters critical for resource development, such as grade, thickness, homogeneity, and tonnage, is difficult because these rocks are so fine grained that physical extraction and preconcentration of metalliferous phases have not so far been feasible. Necessary technological breakthroughs in extracting metals from kerogen-rich shales would enable the commercialization of many of these presently marginal and subeconomic metal deposits. Because the concentration of each metal is low relative to that of commercial ore, and because the most valuable metals are difficult to extract, the principal value of these shales will be based on the aggregate polymetallic assemblage and the hydrocarbon potential.

\section{SPECTRA OF MASSIVE SULFIDE GOSSAN AND FALSE GOSSAN IN THE NEAR INFRARED $(800 \mathrm{~nm}$ TO $2500 \mathrm{~nm})$}

\section{Gary L. Raines, Linda G. McGee, and Steven J. Sutley}

The near-infrared spectra of a suite of outcrop samples of massive sulfide gossans and false gossans representing three different weathering environments were measured and compared with $\mathrm{X}$-ray, scanning electron microscope, and energy dispersive X-ray analyses. Gossans from a humid tropical environment and from an arid environment are represented. The gossans of the West Shasta massive sulfide district represent a weathering environment intermediate between these two extremes. In situ measurements of the near-infrared spectral properties of massive sulfide gossans have not been made. However, commer- 
cially available field and airborne spectrometers are being used by the U.S. Geological Survey to map the distribution of minerals in hydrothermally altered areas in the Southwestern United States with spectral properties similar to those described below.

On the basis of these spectral measurements, true gossans after massive sulfide deposits have spectra in the $800-2500 \mathrm{~nm}$ region that differ from spectra of false gossans. In humid tropical environments, highly leached, newly formed kaolin minerals occur in the gossan causing spectral differences near 1400 and $2200 \mathrm{~nm}$. In arid environments, true gossans preserve talc and minor mica from the massive sulfide deposit; these minerals are not observed in false gossans. This results in spectral differences in the 2200 and $2300 \mathrm{~nm}$ region; in addition, true gossans generally have goethite spectral bands near $900 \mathrm{~nm}$ as opposed to hematite spectral bands near $850 \mathrm{~nm}$ for the false gossans.

False gossans are not known in the West Shasta district. The main gossan type at the largest deposit, Iron Mountain, is a true gossan showing spectral features characteristic of goethite and diaspore, which has distinctive spectral features in the $1400-2500 \mathrm{~nm}$ region. The other gossan type shows the spectral features of goethite, but it contains a less leached mixture of kaolinite plus illite with different distinctive spectral features in the $1400-2500 \mathrm{~nm}$ region. These spectral differences define two groups of West Shasta gossans, inner gossans that are closely associated with large deposits and outer gossans that are associated with the margins of large deposits and with smaller massive sulfide deposits.

\section{THERMODYNAMIC PROPERTIES OF MINERALS}

\section{Richard A. Robie, Bruce S. Hemingway, and John L. Haas, Jr.}

In order to help solve various problems in the geosciences, geologists have developed computerbased models using data of physical and chemical properties of rocks and minerals. The models used to calculate heat budgets or mass exchange between fluids and rock are based upon thermodynamic principles; therefore, the accuracy of the prediction will depend in part upon the accuracy of the thermodynamic data used for each mineral phase in the problem. As part of a coordinated effort to supply accurate data for heat budget calculations and mass transfer models, the U.S. Geological Survey supports the Thermodynamic Properties project and the National Center for the Thermodynamic Data of Minerals.

The Thermodynamic Properties project operates several different types of calorimeters for measuring enthalpies (heats) of formation $\Delta \mathrm{H}^{\circ}$, heat capacities, $\mathrm{C}^{\circ} \mathrm{p}$, and entropies, $\mathrm{S}^{\circ}$, between 5 and $380 \mathrm{~K}$ and relative enthalpies, $\mathrm{H}^{\circ}{ }_{\mathrm{T}}-\mathrm{H}^{\circ}{ }_{298}$ up to $1300 \mathrm{~K}$ for the purpose of obtaining free energy values for minerals. We have recently undertaken a systematic study of the thermodynamic properties of the more common manganese minerals. Heat capacities and entropies have been determined for rhodochrosite $\left(\mathrm{MnCO}_{3}\right)$, hausmannite $\left(\mathrm{Mn}_{3} \mathrm{O}_{4}\right)$, pyrolusite $\left(\mathrm{MnO}_{2}\right)$, bixbyite $\left(\mathrm{Mn}_{2} \mathrm{O}_{3}\right)$, and tephroite $\left(\mathrm{Mn}_{2} \mathrm{SiO}_{4}\right)$, with the intent of determining the stabilities of these phases with respect to temperature, pressure, and oxygen fugacity and thus furthering our understanding of the conditions of formation and the occurrence of manganese ore deposits.

At the National Center for the Thermodynamic Data of Minerals, we have developed an approach for evaluating published experimental data that uses the interrelations among the thermodynamic properties such as volume, heat capacity, entropy, enthalpy, Gibbs energy, equilibrium constants, and electrochemical potentials and a regression procedure for simultaneously fitting all properties for a group of chemically related compounds. The center has produced thermodynamic tables for the major mineral components of basalts and has determined the best values of the oxygen fugacity-temperature relations for the buffers of oxygen in the systems $\mathrm{Fe}-\mathrm{O}$, Ni-O, $\mathrm{Cu}-\mathrm{O}$, and $\mathrm{Mn}-\mathrm{O}$ and for the oxygen buffer assemblages quartz-fayalite-iron and quartz-fayalite-magnetite.

In addition to developing thermodynamic data for minerals, the USGS has revised and updated the Larsen-Berman tables of optical properties of minerals (USGS Bulletin 1627, published 1984) to reflect the additional knowledge since 1934 when the last edition of this handbook was published. The center also supports the FordFleischer File of Mineralogical References. The file, dating back to 1916 , contains more than 100,000 citations related to composition, physical properties, crystallography, optics, chemical reactions, and natural occurrences. 
IDENTIFICATION OF REGIONAL MINERAL RESOURCE TARGETS BY USING ORE DEPOSIT MODELS-TWO EXAMPLES FROM THE EASTERN U.S. EARLY MESOZOIC BASINS

\section{Gilpin R. Robinson, Jr., and David Gottfried}

Ore deposit models developed for diabasehosted massive sulfide deposits and sedimenthosted stratiform sulfide deposits can be applied to the Eastern U.S. early Mesozoic basins (EMB) to identify regional exploration targets. Significant ore deposits of these types are presently unknown in the EMB but are recognized in similar intracontinental rift-basin tectonic settings elsewhere. The models define regional targets by identifying types of associated deposits likely to be found in a given area and by providing criteria to locate favorable geologic-tectonic settings and to identify types of chemical transport, alteration, and fractionation associated with mineralization.

Significant diabase-hosted sulfide deposits occur where basaltic magma is contaminated by favorable crustal material and forms an immiscible sulfide melt. In the EMB, tholeiitic diabase may host and conceal magmatic sulfide deposits of nickel, cobalt, copper, and platinum-group elements that formed in a similar manner to the deposits in the Noril'sk district (Siberia, U.S.S.R.), Insizwa Complex (Transkei, South Africa), or Duluth Complex (Minnesota, U.S.A.). Sulfide accumulations may occur in structural depressions at the base of diabase sheets or as sulfide disseminations in areas of abundant metasedimentary inclusions. Target areas for diabase-hosted sulfide mineralization in the EMB, defined by means of nickel, cobalt, and copper trace-element systematics, are diabase sheets with geochemical trends indicating sulfide fractionation. Additional features favorable for economic mineralization in diabase sheets exhibiting sulfide fractionation include diabase bodies with (1) sulfur isotopic signatures indicating contamination with crustal material and (2) sheet-like diabase bodies with cumulate zones, granophyric differentiates, and abundant metasedimentary inclusions. Our preliminary investigations have identified magma types in Connecticut, Virginia, North Carolina, and South Carolina that have trace-element geochemical trends consistent with sulfide fractionation and are thus favorable targets for exploration.

Sediment-hosted stratiform sulfide deposits found in rift-basin settings are associated with lacustrine and restricted-basin marine sediments. Mineralization appears to be related to the transport of metal-bearing connate brines, either

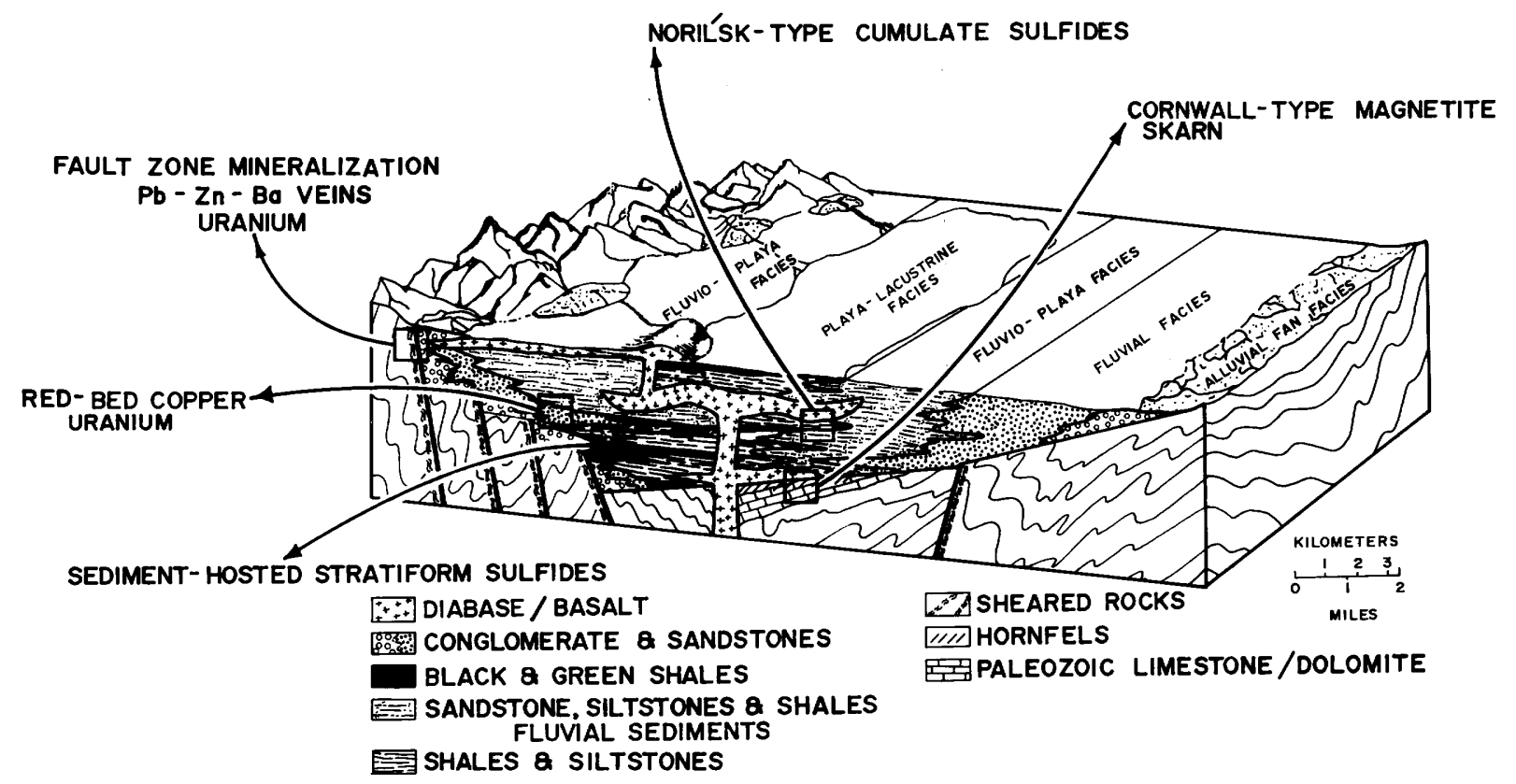

Schematic distribution of facies in the early Mesozoic basins in eastern North America showing some potential mineral resources (modified from C.E. Turner-Peterson, 1980, SEPM-Rocky Mountain Section, Short Course Notes) 
through faults into the depositional basin or through the sediment pile. Favorable factors include (1) syndepositional-postdepositional faults, (2) lacustrine and marine sections with redox changes, (3) anomalous copper, lead, zinc, barium, boron, or silica mineralization, and (4) lead-zinccopper-barium vein occurrences. Occurrences of sandstone-hosted stratabound copper-silver mineralization and vein lead-zinc-copper-barium mineralization are widespread in the EMB and are believed to have formed from the transport of basinal brines to shallow sites of mineral deposition in the Jurassic to Early Cretaceous. Promising target areas for more extensive sedimenthosted stratiform mineralization include Jurassic lacustrine sections in the Hartford, Newark, and Culpeper basins and basal marine sections overlying buried Triassic basins in South Carolina, Georgia, and Florida.

\section{DEVELOPMENT OF DISSEMINATED GOLD DEPOSITS OF CORTEZ, HORSE CANYON, AND GOLD ACRES, NEVADA, AT THE END STAGE OF CALDERA-RELATED VOLCANISM}

\section{James J. Rytuba}

The large disseminated gold deposits of Cortez, Gold Acres, and Horse Canyon, Nevada (total $\mathrm{Au}$ resource of 1.8 million $\mathrm{oz}$.$) , are localized sub-$ parallel to and 4-6 km outside the margin of the Cortez caldera. The caldera is an oval collapse structure, $16 \mathrm{~km}$ in maximum diameter, which resulted from the eruption of the $32.5 \pm 2-\mathrm{Ma}$ Caetano Tuff. Collapse of the caldera was concurrent with eruption of the ash-flow tuff, resulting in the filling of the caldera with more than $1.5 \mathrm{~km}$ of tuff and interstratified collapse megabreccia. The Caetano Tuff is a calc-alkaline rhyolite that is strongly zoned with respect to $\mathrm{Hg}, \mathrm{Rb}, \mathrm{Sr}, \mathrm{Nb}, \mathrm{Zr}$, and $\mathrm{Ba}$. Highest contents of $\mathrm{Hg}, \mathrm{Nb}$, and $\mathrm{Rb}$ occurred in the early phase of the eruption and indicate roofward enrichment of these elements in the magma chamber. Highest contents of $\mathrm{Ba}, \mathrm{Sr}$, and $\mathrm{Zr}$ occur in the late erupted tuff and indicate roofward depletion in the magma chamber. In contrast, the ore metals ( $\mathrm{Au}, \mathrm{Ag}, \mathrm{As}, \mathrm{Sb}, \mathrm{Tl}, \mathrm{Cu}, \mathrm{Pb}$, $\mathrm{Zn})$ are not zoned in the tuff. Gold content is uniformly low, ranging from $<1 \mathrm{ppb}$ to $1.3 \mathrm{ppb}$, and is similar to the gold content of other calcalkaline rhyolites. The contents of As, <1.02.4 ppm; $\mathrm{Pb}, 1.6-7.2$ ppm; $\mathrm{Zn}, 23-57 \mathrm{ppm} ; \mathrm{Cu}$,
7.6-16 ppm; and $\mathrm{Sb}$ and $\mathrm{Tl},<1 \mathrm{ppm}$, are all similar to or lower than those reported for other calcalkaline rhyolites; only $\mathrm{Hg}, 0.5-3.1 \mathrm{ppm}$, is anomalously high.

The gold deposits occur in the Roberts Mountains Formation of Silurian and Devonian age and the Wenban Limestone of Devonian age, which have been intruded by rhyolite porphyry dikes. The ore bodies consist of disseminations of gold, quartz, and pyrite and contain anomalous concentrations of $\mathrm{As}, \mathrm{Sb}$, and $\mathrm{Tl}$. The Cortez ore bodies are localized adjacent to rhyolite porphyry dikes and have a strike and dip similar to those of the dikes. The ore bodies at Gold Acres and Horse Canyon are also, in part, localized by rhyolite porphyry dikes. Each deposit contains dikes that have $\mathrm{Rb} / \mathrm{Sr}, \mathrm{Nb} / \mathrm{Zr}$, and $\mathrm{Ba} / \mathrm{Sr}$ ratios similar to those in the Caetano Tuff, indicating the intrusions and tuff are comagmatic. The original content of ore metals in the dikes was low and similar to that in the Caetano magma. Low levels of $\mathrm{Au}$, $\mathrm{As}$, and $\mathrm{Sb}$, and locally $\mathrm{Tl}, \mathrm{Cu}$, and $\mathrm{Ag}$, were introduced into the dikes during mineralization. $\mathrm{Rb}$ is depleted in the more intensely altered dikes, and $\mathrm{K}$-Ar ages of biotite, $34.8 \pm 1.1 \mathrm{Ma}$, from Cortez dikes have been reset by the hydrothermal event. Although the age of the Caetano Tuff and mineralization fall within the analytical uncertainty of the $\mathrm{K}$-Ar ages, the presence of mineralization in the outflow facies of the tuff and dikes indicates that the hydrothermal event occurred after caldera collapse and during the end stage of the caldera cycle. The magmatic event provided the heat for the hydrothermal systems but was not the source of the metals, as indicated by the low contents and absence of zoning of ore metals in the Caetano magma and the absence of anomalous $\mathrm{Hg}$ in the ore deposits even though the Caetano magma contained anomalously high $\mathrm{Hg}$.

\section{HIGH-ALUMINA HYDROTHERMAL ALTERATION SYSTEMS AND THEIR ROLE IN MINERAL EXPLORATION, SOUTHEASTERN UNITED STATES}

\section{R.G. Schmidt and T.L. Klein}

Large subvolcanic to solfataric hydrothermal systems characterized by an abundance of silica and high-alumina minerals (andalusite, pyrophyllite, topaz, dumortierite), very intense alteration of large volumes of rock, and profound 
changes in bulk composition are found at many localities worldwide and can be considered to be a subclass of porphyry-type alteration systems. Examples include Kounrad mine, Kazakhstan, U.S.S.R.; El Salvador mine, Chile; La Granja deposit, Peru; Island Copper mine, British Columbia, Canada; and Equity Silver silver-copper-gold mine, British Columbia. The alteration zones contain disseminated pyrite and traces to extractable quantities of gold, silver, copper, molybdenum, tin, and other metals. Fluorine, as topaz, is generally more abundant than boron, but tourmaline and (or) dumortierite is the abundant halogen mineral in some systems. Bismuth, arsenic, lead, and zinc are also commonly present. These systems are transitional to shallower solfataric and hot spring deposits and, with greater K-silicate alteration, into typical subvolcanic porphyry copper deposits. The presence of significant zones of high-alumina alteration within certain major porphyry-type deposits and prospects worldwide suggests that this type of alteration is a potentially useful exploration guide. Studies of several high-alumina deposits in metavolcanic rocks of the Carolina slate belt indicate similar alteration and metallogenic associations and suggest these deposits be seriously evaluated for their base- and precious-metal potential.

The Carolina slate belt, extending from Georgia to Virginia, is a thick sequence of metamorphosed lava flows and volcaniclastic rocks that probably formed in a volcanic arc environment of late Precambrian to early Paleozoic age. These rocks probably formed in diverse environments including island arcs and continental margins.

About 40 large bodies of high-alumina altered rocks have been identified within volcanic rocks of the slate belt. Ten to fifteen share many features of porphyry-type systems and consist of large, generally equidimensional alteration zones. The remainder have a tabular form. High-alumina minerals (pyrophyllite, andalusite, and sericite) have been mined in the slate belt from about 15 deposits of both types for industrial purposes, and four deposits are presently being mined. Former gold mines or gold prospects occur in at least three of the porphyry-like systems and adjacent to one of the tabular bodies.

The equidimensional porphyry-like alteration systems in the Carolina slate belt are from one to several kilometers in diameter. Tilting and erosion permit us to get cross-sectional views into the systems over a vertical distance of perhaps as much as three kilometers. Alteration in these systems is dominated by intense silicification yielding a quartz granofels consisting of over 80 percent quartz commonly accompanied by minor pyrophyllite ( \pm topaz) and usually by pyrite. Pods of pyrophyllite, andalusite, and kaolinite occur locally within the highly silicified rocks or as peripheral alteration zones. The geochemical signature of these deposits is the suite $\mathrm{Cu}, \mathrm{Mo}, \mathrm{Sn}$, $\mathrm{B}$, and $\mathrm{F}$, with sporadic $\mathrm{As}, \mathrm{Au}, \mathrm{Bi}, \mathrm{Li}, \mathrm{Pb}$, and $\mathrm{Zn}$. Some tabular deposits have little or no silicified rock in them, and most lack associated Sn or abundant F; each may have formed by intense hydrothermal alteration along shear zones, shallow solfataric processes, or alteration on the sea floor by ponding of hot, acidic and reducing brines. We assume that the tabular bodies are genetically related to the porphyry-like bodies, but data are lacking to document this connection.

\section{MULTIPLE EPISODES OF MINERALIZATION IN THE SOUTHERN TOQUIMA RANGE, NYE COUNTY, NEVADA}

\section{Daniel R. Shawe}

The southern Toquima Range is a complex geologic terrane formed by multiple sedimentation, tectonism, igneous intrusion and extrusion, and mineralization. During Cambrian and Ordovician time, marine quartzite, silty and limy argillite, argillite, limestone, dolomite, and chert were deposited in a continental shelf-slope environment, and during Permian time clastic rocks were laid down. Geochemical data indicate that some Paleozoic units contain concentrations of metals possibly of submarine exhalative origin. Thrust faulting during Paleozoic and Mesozoic time stacked the Paleozoic sedimentary rocks into a sequence of thin thrust plates. The rocks were repeatedly intruded and mineralized near numerous igneous centers from the end of thrusting through most of the Tertiary.

Three large granitic plutons intruded the Paleozoic rocks in Cretaceous time, probably near the close of regional thrust faulting, and later they were domed, metamorphosed, and mineralized. Base-metal sulfide-bearing skarn and tungstenbearing quartz veins were formed at places in and 
near the plutons; production from them has been insignificant. The skarn deposits contain small amounts of gold. Economic silver deposits in Paleozoic rocks near Belmont may be related to nearby Cretaceous granite, though most of the silver possibly was introduced, or reworked from earlier deposits, during a Tertiary igneous event.

In the Oligocene a granodiorite stock and a swarm of rhyolite and andesite dikes intruded the granite pluton and adjacent rocks east of Round Mountain; the intrusion was accompanied by tourmaline and base- and precious-metal sulfide mineralization of little economic interest. Concurrently, tungsten-bearing veins in granite near the Oligocene intrusive bodies were remineralized with base- and precious-metal sulfides.

Near the end of the Oligocene and beginning of the Miocene, extensive volcanic activity commenced in the southern part of the Toquima Range. The Mount Jefferson and Manhattan calderas, and perhaps other unrecognized structures, collapsed during eruption of voluminous silicic ash-flow tuffs. Shortly after formation of the Manhattan caldera, a large stockwork and disseminated gold deposit was formed in rhyolitic ashflow tuff at Round Mountain about $5 \mathrm{~km}$ north of the caldera. The gold deposit at Round Mountain is one of the largest in the United States; it also contains significant amounts of silver. At about the same time, silver-gold mineralization occurred in rhyolitic ash-flow tuff at Jefferson, at the south margin of the Mount Jefferson caldera.

Later in Miocene time, extensive economic gold mineralization occurred in Cambrian phyllitic argillite, limestone, and quartzite in the Manhattan district, along the south margin of the Manhattan caldera. A possible igneous rock source has not been recognized, but it may be buried along the south margin of the caldera.

Mercury deposits of probable late Tertiary age formed in several places near the margins of granitic plutons and peripheral to the Manhattan and Mount Jefferson calderas. Cinnabar was mined in and near granite bodies and from Paleozoic rocks in the east part of the Manhattan district.

The Cretaceous, Oligocene, OligoceneMiocene, and Miocene mineralized systems in the southern Toquima Range are large, each covering several square kilometers, and the younger systems spatially overlap older ones. Geologic, geochemical, and lead-isotope data suggest that both derivation of metals from host rocks and remineralization of older systems were important in forming the mineral deposits. Many geologic environments, including favorable host lithologies (highly fractured rocks of all kinds, organicmatter-rich carbonate and other sedimentary rocks), high- and low-angle faults, and caldera margins, are potential sites for large metal deposits such as porphyry copper-molybdenum systems, gold-bearing skarns, high-grade goldsilver lodes, Carlin-type gold deposits, and stockwork-disseminated gold-silver deposits in volcanic rocks.

\section{CHARACTERISTICS OF LODE-GOLD DEPOSITS IN THE PRINCE WILLIAM SOUND REGION, SOUTHERN ALASKA}

\section{Miles L. Silberman and Dawn J. Madden}

Lode-gold deposits in low- to medium-grade metamorphosed, accreted sedimentary rocks are common and economically important throughout the world. Perhaps the best known examples of this deposit type are in the Klamath Mountains of northern California. Other occurrences are found in South Island (New Zealand), Papua New Guinea, southwestern Alaska, and parts of the Mother Lode Belts of central California. Because of the importance of deposits of this type, we decided to study in detail one region where they occur in order to determine their mechanisms of formation and localization. The deposits near Prince William Sound, southern Alaska, are particularly suited for detailed study now, after ten years of regional and local geologic study, when a comprehensive regional picture is emerging.

The deposits occur as narrow fissure veins emplaced along faults, fractures, and shears in metasedimentary rocks of the Upper Cretaceous Valdez Group in the Prince William Sound region. In some mining districts, the veins are peripheral to and cut small granitic stocks and plugs that intruded the metasedimentary rocks between 55 and $50 \mathrm{Ma}$ and again at $35 \mathrm{Ma}$. In other districts, the veins occur in metasedimentary host rocks that lack plutonic intrusions but contain small felsic to intermediate dikes, which are locally altered and cut by the veins.

The veins consist of quartz and minor calcite; they contain generally low concentrations of sulfide minerals, predominantly arsenopyrite, and 


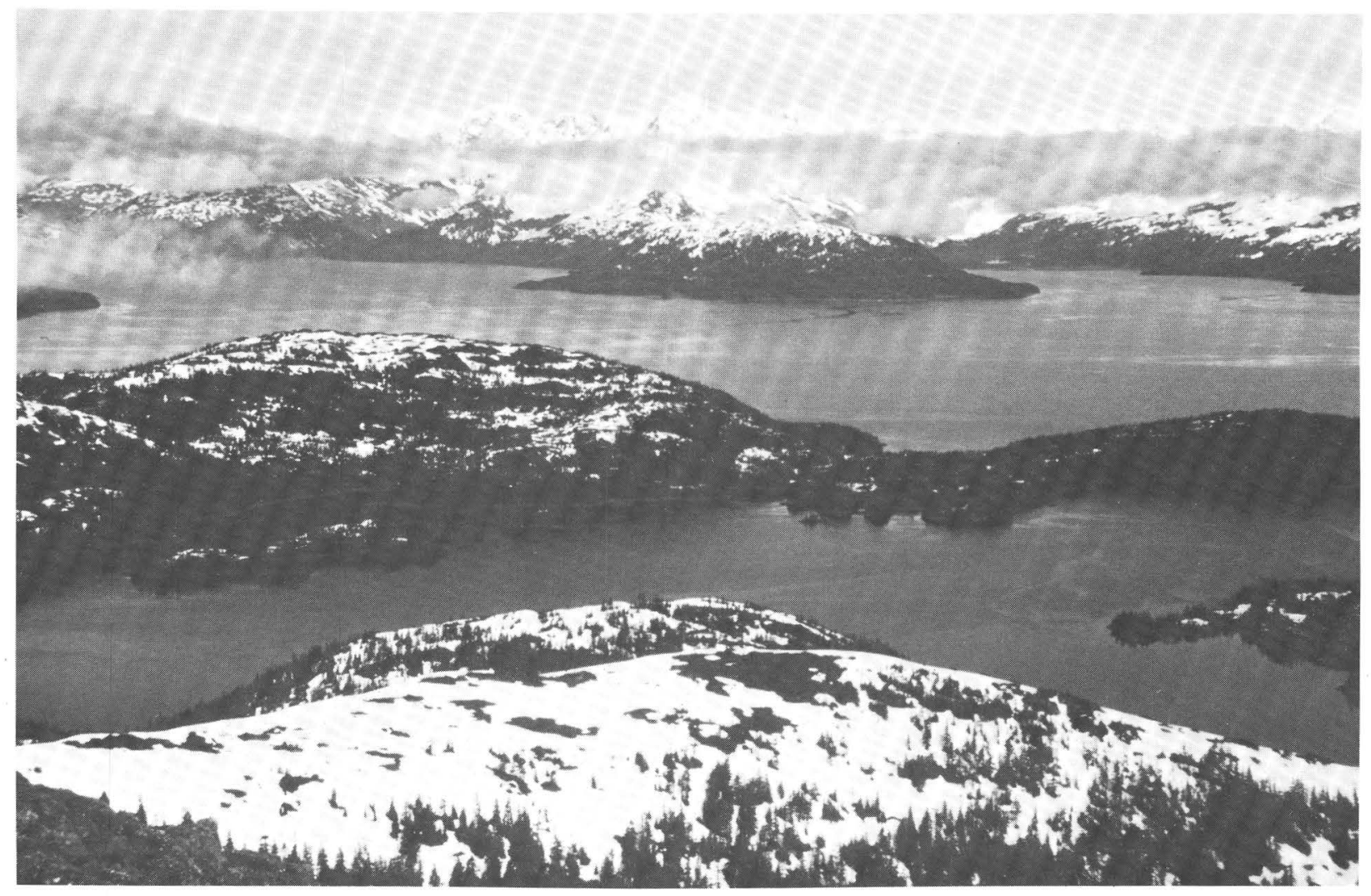

Prince William Sound and Chugach Mountains, July 1975

associated pyrite, sphalerite, galena, and chalcopyrite. Native gold is the principal economic metal; past lode production is 131,000 ounces. Ag and As are the most common trace elements associated with the $\mathrm{Au}$; variable amounts of $\mathrm{Sb}, \mathrm{Hg}, \mathrm{Cu}, \mathrm{Pb}$, $\mathrm{Zn}$, and $\mathrm{Ba}$ are also present. Detailed elementdispersion studies at the Hope-Sunrise and Girdwood mining districts in the Chugach Mountains, west of Prince William Sound, indicate that the minor-element content of the veins reflects local variations in the metasedimentary host rocks. Plutonic rocks and dikes that are associated with gold mineralization have a characteristic REE pattern marked by strong depletion relative to chondrites and no Eu anomaly. In contrast, igneous rocks not associated with mineralization have nonuniform REE patterns.

$\mathrm{K}$-Ar ages of metamorphism, and of alteration associated with the gold-bearing veins, fall within the periods of granitic intrusion. Oxygen- and hydrogen-isotope ratios indicate that the veins were deposited by fluids with a strong meteoric

water component and a low water-to-rock ratio. Sulfur-isotope ratios suggest derivation of sulfur from the host rocks, probably by a process involving diffusion. The similarity of $\mathrm{K}-\mathrm{Ar}$ ages of regional metamorphism, granitic intrusion, and mineralization suggests that these processes are related. The sulfur-isotope data and the similarity of vein and host-rock minor-element contents suggest that ore and related metals derive from the host rocks. These metals probably were leached by hot fluids largely of meteoric origin. The fluids were heated by a combination of metamorphism and granitic intrusion.

From the isotopic and geochemical data, the processes that resulted in gold mineralization can be reconstructed as

Accretion (60-55? Ma)
Allochthonous terranes impinge on continental margin, penetrative deformation, folding, axial-plane cleavage, thickening of accreted wedge. 
Metamorphism Heating of thickened wedge, (55-62 Ma)

Intrusion

(55-50 Ma)

Uplift

Mineralization

(55-53 Ma)

high-grade metamorphism at depth, lower grade near surface. Generation of metamorphic fluids, which leach metals from wedge sediments. Formation of metamorphic segregation quartz veins.

Migration of melts to shallow depth, and emplacement as plutons and dikes. Contact metamorphism, faulting.

Uplift by thermal expansion, or loss of compression, opening of fractures, extensional shearing.

Influx of meteoric water, mixing with metamorphic fluids as they ascend, deposition of quartz, calcite, metals in open fractures and shears. Late stages of process driven by heat of anatectic granites.

\section{METALLOGENY OF ARCHEAN AND PROTEROZOIC TERRANES IN THE LAKE SUPERIOR REGION}

\section{P.K. Sims}

A tectonostratigraphic approach to metallogeny provides a framework within which to relate existing and possible undiscovered mineral deposits to their host terranes.

Four major Precambrian tectonostratigraphic terranes have been delineated in the Lake Superior region of the United States and Canada. Two of these-an Archean greenstone-granite terrane (about 2,700 Ma) and an Archean gneiss terrane $(3,550-2,600 \mathrm{Ma})$-are partly covered by a continental-margin sequence of Early Proterozoic (about 2,000-1,900 Ma) miogeoclinal rocks assigned to the Marquette Range Supergroup and its equivalents in Minnesota. The third is an Early Proterozoic oceanic-arc assemblage-the Wisconsin magmatic terrane (about 1,900-1,800 Ma)- that mainly lacks an Archean basement. The fourth is a Middle Proterozoic (Keweenawan) rift assemblage-the Midcontinent rift system $(1,100$ Ma). The two Archean terranes were tectonically joined in Late Archean time, and the Early Proterozoic oceanic-arc assemblage was accreted to the North American continent about 1,850 Ma, during the Penokean orogeny. The Midcontinent rift system is a major intracontinental rift that aborted before much crustal separation.

Major known or potential ore deposits occur in all these terranes except the Archean gneiss. They can be grouped into two classes according to the tectonic environment in which they formed: islandarc crust and continental crust.

In island-arc crust, four types of major mineral deposits exist, but only one is common to both the Early Proterozoic Wisconsin magmatic terrane and the Archean greenstone-granite terrane: volcanic-hosted $\mathrm{Cu}-\mathrm{Zn}$ type massive sulfide deposits. The massive sulfide deposits in the Wisconsin magmatic terrane are in calc-alkaline volcanic rocks having island-arc chemical affinities; those in the Archean terrane apparently are mainly in felsic rocks of both tholeiitic and calc-alkaline affinities. The other deposits in island-arc crust-Algoma-type iron formations, ultramafic- and gabbro-hosted $\mathrm{Cu}-\mathrm{Ni}$ deposits, and stratabound and intrusion-hosted $\mathrm{Au}$ depositsare virtually restricted to Archean rocks and, except for the iron formations, occur mainly in Canada.

In continental crust, deposits in the Early Proterozoic epicratonic rocks are the vast Superiortype iron formations and the apparently subeconomic carbonate-hosted copper deposits. Major conglomerate-hosted uranium deposits occur in the Huronian Supergroup in the Lake Huron area of Canada, a continental-margin accumulation like the miogeoclinal sequence in the Lake Superior region. The Middle Proterozoic rocks of the Midcontinent rift system have deposits containing chalcophile elements, which ultimately were derived from magmas ascending from the mantle. The principal developed deposits are the famous volcanic- and sedimentary-hosted copper deposits on the Keweenawan Peninsula. A major resource for the future is the large, marginal-grade gabbrohosted $\mathrm{Cu}-\mathrm{Ni}$ deposits of the Duluth Complex in northern Minnesota. 


\section{SOME RECENT DEPOSIT MODELING EFFORTS}

\section{D.A. Singer and D.P. Cox}

A compilation of 62 descriptive and 37 gradetonnage models, which was published in 1983, pro vides a starting point for a larger deposit modeling effort useful for resource assessment and exploration. The classification of deposits is empirical rather than genetic and is based on a study of wellknown deposits. Use of data from many deposits increases the robustness of the models, and emphasis on lithologic-tectonic associations allows the use of geology to indicate which resources are possible in a region. The deposit models make possible effective project design for assessments and exploration and provide a basis for quantitative assessments.

Tonnages and average grades of well-explored deposits of each type are used to characterize grades and tonnages of undiscovered deposits in geologically similar settings. Variation of grade and tonnage within deposit types tends to be small compared with variation among deposit types. Graphical presentation of grade-tonnage models is particularly effective in showing differences among deposit types and the likelihood of occurrence of deposits having grades and tonnages above specified limits.

Some additional benefits of this modeling effort have been the recognition that there are two types of podiform chromite deposits; one type, found in the cordillera, has a median size of 120 tonnes, whereas podiform deposits in Turkey, the Philippines, and elsewhere have a median size of 19,000 tonnes. Although the sample of deposits used in the larger type of podiform deposit is probably size-biased in favor of large deposits, the sample of deposits from the cordillera is not sizebiased, and statistically it is nearly impossible for the larger deposits from Turkey to have come from the same population as the smaller cordillera deposits.

A recent analysis of 55 porphyry copper deposits that have reported grades for $\mathrm{Cu}, \mathrm{Mo}$, and $\mathrm{Au}$ demonstrates a continuum between (1) goldrich deposits emplaced at a median depth of $1 \mathrm{~km}$, with a median size of 110 million tonnes and a median content of 2.6 percent magnetite in the potassic alteration zone, and (2) molybdenum-rich deposits emplaced at a median depth of $3.6 \mathrm{~km}$, with a median size of 500 million tonnes and little magnetite. Between these end members is an economically important group containing significant amounts of gold and molybdenum.

\section{TIN, MOLYBDENUM, AND OTHER METAL ELEMENTS IN SILICIC MAGMAS AND THEIR RELATION TO FLUORINE AND CHLORINE DISTRIBUTION}

\section{Robert L. Smith}

Lithophilic metal elements, $\mathrm{F}, \mathrm{Cl}$, and probably $\mathrm{H}_{2} \mathrm{O}$, are commonly enriched in the tops of silicic magma chambers. Pyroclastic deposits from caldera-forming eruptions provide evidence that chemical gradients, spanning ten-fold enrichments of lithophilic elements and one hundred-fold depletions of refractory elements, may sometimes occur in the silicic magma reservoirs. The most fractionated liquids in these magmas contain the fewest phenocrysts and may be erupted in large volume, followed by more phenocryst-rich, less fractionated magma.

Data from the Bandelier Tuff, New Mexico, show that the phenocrysts are in equilibrium at all levels with the liquid (glass) that surrounds them and thus are evidence that the phenocryst gradient was superimposed on a preexisting chemical gradient in the liquid. These highly fractionated, phenocryst-poor magmas preceded final solidification of the magma reservoir by more than one million years; the chemical gradients waxed and waned with alternating periods of repose and volcanic bleeding of the system. Thus, clearly, the timing of stock emplacement in such systems is critical to magmatic metal and volatile concentrations and may not be systematic.

Geochemical studies of obsidians and volcanic systems like the Bandelier Tuff indicate that distribution patterns of metal elements are systematic and are strongly correlated with $\mathrm{F}$ and $\mathrm{Cl}$ distribution. For example, $\mathrm{Sn}$ and $\mathrm{Mo}$ are concentrated with $\mathrm{F}$ plus $\mathrm{Cl}$ in nonhydrated natural glasses, but $\mathrm{Sn}$ is also concentrated with $\mathrm{F}$ at very low $\mathrm{Cl}$ levels whereas Mo is not. The highest Mo concentrations $(20 \mathrm{ppm})$ are found in Cl-rich peralkaline rhyolites, yet peralkaline magmas are not known to generate porphyry Mo deposits. Some other factors (probably $\mathrm{H}_{2} \mathrm{O}$ ) in subalkaline magmas $(\mathrm{Mo}<10 \mathrm{ppm})$ control Mo release during stock emplacement and crystallization. $\mathrm{Sn}$ is 
enriched in all F-rich glasses but reaches highest concentrations in peraluminous compositions. The highest known Sn concentration (>150 ppm) in an obsidian is found in the rare Macusanite glass from Peru. This glass also contains exceptionally high concentrations of $\mathrm{Rb}, \mathrm{Cs}, \mathrm{Li}, \mathrm{B}, \mathrm{W}$, and $\mathrm{F}$ and exceptionally low concentrations of $\mathrm{Zr}, \mathrm{Hf}$, Th, $\mathrm{Mo}, \mathrm{Cl}$, and rare-earth elements. The glass has the composition of a lithium pegmatite, and the Sn concentration probably far exceeds that required for all other types of Sn deposits associated with silicic igneous rocks. Wood tins, including the socalled Mexican-type tins, probably require at least $10 \mathrm{ppm} \mathrm{Sn}$ in the magma, but this threshold concentration may vary with fluid composition and rock permeability.

$\mathrm{Sn}, \mathrm{Mo}, \mathrm{F}$, and $\mathrm{Cl}$ are mobile during crystallization of rhyolitic and granitic rocks; hence their abundances are reliable indicators of initial magmatic concentrations only in unaltered glassy rocks. In crystallized silicic rocks, stable elements $(\mathrm{Nb}, \mathrm{Ta}, \mathrm{Zr}, \mathrm{Hf}, \mathrm{Th}$, and $\mathrm{Rb})$ may be used in various combinations to reconstruct approximate initial magmatic values for mobile elements and hence have potential for exploration. However, exploration strategies based on stable-element patterns require a knowledge of chemical variation as a function of tectonic environment.

\section{MINERAL RESOURCE ASSESSMENT OF THE SAN ISABEL NATIONAL FOREST, COLORADO; A PROTOTYPE FOR 1:250,000-SCALE MULTIDISCIPLINARY ASSESSMENTS "FROM THE LITERATURE"}

\section{Richard B. Taylor and John S. Dersch}

This mineral resource assessment of the San Isabel National Forest is based entirely on published data and is a prototype of what may become a series of assessments that use available geologic, geochemical, and geophysical information. Land-use planning requires evaluation of the mineral resource potential of Federal lands at a rate exceeding the capacity, both budget and personnel, of the USGS to conduct field surveys. This study was undertaken to establish a methodology and to test the feasibility of "literature" assessments at a scale of $1: 250,000$, a scale chosen to best balance planning needs against the detail available from published information. The San Isa- bel National Forest covers $1,940 \mathrm{mi}^{2}\left(4,970 \mathrm{~km}^{2}\right)$ in the southern Rocky Mountains and extends $160 \mathrm{mi}(260 \mathrm{~km})$ south-southeast, from north of Leadville to south of the Spanish Peaks. It was selected for this study because of the diversity of its mineral deposits, which include a part of the Colorado Mineral Belt, and because the amount of information available is typical of that available for much of the Western United States. Responsibility for assessing locatable and leasable minerals was taken by the USGS, for salable minerals by the Forest Service; the project was conducted jointly, and information was shared throughout the work.

The procedures used for this assessment were fundamentally similar to those of the initial phase of any mineral resource assessment project, except that the results have been published. Without fieldwork to obtain new data, the quality and nature of the assessment data inevitably vary from place to place. Procedures were as follows:

(1) Collection of available geologic maps and compilation of a coherent geologic map at 1:250,000 from the disparate pieces. Maps published for the entire area (parts of the Leadville, Montrose, Pueblo, and Trinidad $1^{\circ} \times 2^{\circ}$ quadrangles) were supplemented by other maps, including those from graduate theses and recent mineral surveys of Wilderness Study Areas.

(2) Collection of available geochemical and geophysical data and compilation of selected parts at a 1:250,000 scale. Sets of NURE (National Uranium Resource Evaluation) geochemical data were examined from the four stream-sediment surveys that covered the area, and 11 elements (Co, Cu, Cr, Fe, Mn, Ni, Pb, Sn, Th, U, and $\mathrm{W}$ ) were selected as useful and analytically sufficiently reliable for assessment purposes. Plots of these elements were made for each of the four $1^{\circ} \times 2^{\circ}$ sheets. Geochemical data from Wilderness surveys were examined but were not compiled at the scale of the San Isabel study. Regional gravity and aeromagnetic maps were collected for the entire area, and selected maps were reduced to 1:250,000 scale. No attempt was made to recompile and recontour data. The surveys were made over two decades, and the diversity of the data was so great as to make the effort of integration and recontouring unwarranted.

(3) Collection and examination of data on

${ }^{9}$ John S. Dersch, U.S. Department of Interior, Forest Service. 
mineral deposits. This included study of published mine and district descriptions, computerized data files, and plotting of mine and prospect location information from 1:24,000-scale topographic maps at 1:250,000 scale.

(4) Construction of occurrence and genetic resource models, called "deposit types" in this report. The models are based on deposits both within and outside the forest. Each model was fine-tuned to local geology and to assessment data available for the area. For example, the assessment models are restricted to analytical data available for the area because no opportunity was afforded either to collect new samples or to reanalyze existing samples.

(5) Evaluation of the terrane within the forest boundaries and assignment of levels of mineral resource potential (and levels of certainty of assessment) to areas for specific commodities on the basis of specified deposit types. Seventeen deposit types were used in the San Isabel evaluation.

(6) Publication of results, including text and 1:250,000-scale geologic and mineral resource maps. The San Isabel study is reported in the publication listed at the end of this abstract.

The credibility of an assessment "from the literature" relies in part on the adequacy of the literature and the time available for search, compilation, and interpretation and in part on the availability of geologists with experience in the area so that compiled data is interpreted as more than just words and numbers.

\section{Reference Cited}

Taylor, R. B., Stoneman, R. J., and Marsh, S. P., 1984, An assessment of the mineral resource potential of the San Isabel National Forest, south-central Colorado, with a section on salable minerals by J. S. Dersch, U.S. Department of Agriculture, Forest Service: U.S. Geological Survey Bulletin 1638, 42 p.

\section{PRELIMINARY RESULTS OF AN ALVIN DIVE PROGRAM ON ACTIVE HYDROTHERMAL VENTS AT THE SOUTHERN JUAN DE FUCA RIDGE}

\section{USGS Juan de Fuca Study Group ${ }^{10}$}

In September 1984, the USGS Juan de Fuca Study Group conducted 8 ALVIN submersible dives to investigate hydrothermal activity on the southern Juan de Fuca Ridge. Three primary vent sites along a $6-\mathrm{km}$ segment of ridge were sampled and mapped. Traverses across the axial valley floor confirmed the general volcanic and tectonic features mapped by deep-towed photography in 1983. From the inner valley walls to the axis, the $1-\mathrm{km}$-wide, symmetric valley floor is characterized by the following sequence of volcanic features: smooth lobate sheetflows, lobate sheetflows with numerous small collapse pits, a subsided lava lake, and a 10- to 30-m-deep, 50-m-wide cleft along the center of the valley floor. Sonar images revealed that the central cleft is remarkably linear and continuous within the study area, although it is locally offset by a few tens of meters.

Hydrothermal vents and associated fauna and (or) sulfide deposits were observed on all dives. All of the hydrothermal activity occurs within or at the margins of the central cleft. Features forming conduits for hydrothermal fluids include fractures along the base of the walls of the central cleft, basaltic pillars, and hollow lobate flows. Both lowtemperature, diffuse flow and high-temperature (maximum measured temperature $283^{\circ} \mathrm{C}$ ), blacksmoker chimneys were observed. Water samples from 9 vents have a minimum measured $\mathrm{pH}$ of 3.2 and a maximum $\mathrm{H}_{2} \mathrm{~S}$ in excess of $3 \mathrm{mmol} / \mathrm{kg}$. Sulfide deposits occur as fields of chimneys and spires from 1 to $3 \mathrm{~m}$ high and 10 to $50 \mathrm{~cm}$ in diameter. Some larger chimneys as much as $3 \mathrm{~m}$ in diameter and $9 \mathrm{~m}$ high were observed. The deposits are usually surrounded by a nearly continuous blanket of orange-brown hydrothermal sediment and (or) a white to yellow bacterial(?) mat.

Recovered sulfide samples are predominantly the tops of chimneys or spires, which typically contain greater than 80 percent $\mathrm{ZnS}$ (determined by shipboard examination of hand specimens and limited microscopic inspection). The chimneys show crude concentric banding defined by colloform banded to dendritic sphalerite and have a porous texture. The concentric banding is accentuated by bands rich in one or more of the minerals pyrite, marcasite, anhydrite, wurtzite, chalcopyrite, and pyrrhotite. Less typical samples contain more abundant pyrite (up to 80 percent) intergrown with sphalerite and chalcopyrite or have interior conduits completely lined with chalcopyrite,

${ }^{10}$ W.R. Normark, J.L. Morton, J.L. Bischoff, R. Brett, R.T. Holcomb, E.S. Kappel, R.A. Koski, S.L. Ross, W.C. Shanks III, J.F. Slack, K.L. von Damm, R.A. Zierenberg. 


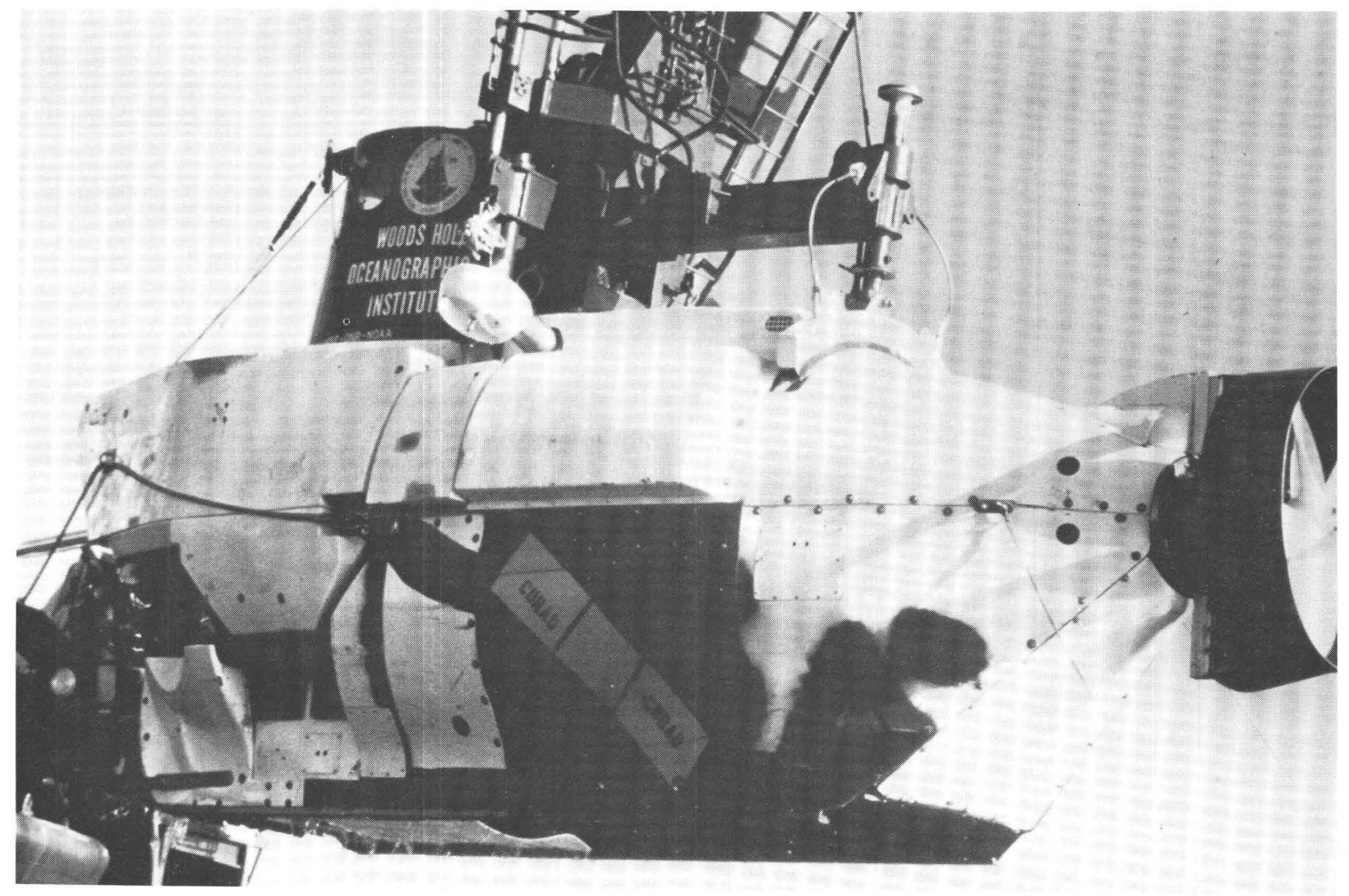

Deep Submergence Research Vehicle ALVIN

which is intergrown with sulfate and sphalerite toward the exterior.

Benchmarks, consisting of floats with unique markings, were placed at each of the sampling sites. The benchmarks should allow us to observe physical changes in the deposits, both growth and dissolution, during subsequent deep-towed photographic or submersible work.

\section{MICROBIOLOGY OF SOIL DERIVED FROM A COPPER DEPOSIT}

John R. Watterson, Sarah S. Elliott, Nancy L. Parduhn, and David M. Updegraff

Malachite, azurite, and other copper minerals are present in soils developed on a steeply dipping copper deposit of Eocene age, the Cotter Basin Prospect, Lewis and Clark County, Montana. For approximately $80 \mathrm{~m}$ across the deposit there are soils (some with $>1$ percent $\mathrm{Cu}$ ) inhabited only by the "Montana silver plant," Eriogonum ovalifolium, sparse grasses, lichens, and soil microorganisms. A mixed forest flanks the deposit, but trees do not grow in the metal-rich soil, and conifers bordering the deposit are dwarfed and deformed. The large and abrupt geochemical gradients that exist here make this an excellent place to study the influence of natural high metal concentrations on the soil microflora.

A total of 28 samples was collected from the upper $10 \mathrm{~cm}$ of soil in a traverse across the deposit; about half of the samples were located over the deposit, and half were from the forest on either side. Detailed chemical and microbiological studies on these soils over the last two years demonstrate that both the absolute number of viable, aerobic, spore-forming bacteria (mostly Bacillus species) and the penicillin resistance of these bacteria increase over the deposit. The bacteria responsible for this penicillin resistance were found to be $B$. cereus. Purified and identified $B$. cereus cultures from all but two traverse sites 
were tested for their relative resistance to the salts of 20 metals and 27 antibiotics. The pattern of antibiotic resistance defined the location of the deposit much more clearly than the pattern of resistance to any metal.

Microfungi were also isolated from the soils over the deposit because certain species are known to produce penicillin and other antibiotics. A purified colony of the most prevalent soil fungus in the deposit area (a Penicillium sp.) was shown in bioassay tests to actively produce penicillin and other unidentified antibiotics. Bacillus populations over the deposit (predominantly $B$. cereus) showed little or no inhibition when grown with the Penicillium sp., whereas Bacillus populations away from the deposit were strongly inhibited. In addition, $B$. cereus isolates from over the deposit were found to be capable of normal germination and growth in ultrapure water with no other nutrient than mycelium tufts from the Penicillium sp. from the same site. $B$. cereus is the only known Bacillus sp. that can also "eat" microfungi, and this is why $B$. cereus is uniquely suited to live in this "toxic" metalliferous soil. Multiple antibiotic resistances are thus shown to be far more decisive criteria than metal resistances for the success of $B$. cereus over the deposit.

\section{PROCESSING OF LANDSAT IMAGERY TO MAP SURFACE MINERAL ALTERATION ON THE ALASKA PENINSULA, ALASKA}

\section{Frederic $H$. Wilson and James E. York ${ }^{11}$}

Landsat images were digitally processed to facilitate assessment of the mineral resources of the Port Moller, Stepovak Bay, and Simeonof Island 1:250,000 quadrangles. Field mapping and assessment of these quadrangles were begun in 1983 as part of the Alaska Mineral Resource Assessment Program (AMRAP). It was quickly realized that time and budget constraints would limit mapping coverage. Therefore, at the suggestion of Roger Ashley, we used existing Landsat multispectral scanner imagery to aid in locating surface alteration, which could be field checked or related to stream-sediment or hand-sample geochemical data.

\footnotetext{
${ }^{11}$ James E. York, Technicolor Government Services Inc.; work performed under U.S. Geological Survey Contract Number 14-08-00120129.
}

Landsat imagery can delineate areas of surface alteration by emphasizing their particular spectral characteristics. Areas of primarily rock and soil were first separated from areas of vegetation, snow, and water by using a digital image of Landsat land cover classes prepared for another study. Using data from the rock and soil class, we tested various processing techniques, including contrast stretches, band ratios, classification based on spectral brightness, principal component transformations, and color transformations. The best delineation of known altered areas was obtained with a principal component transformation. This transformation is defined such that the first principal component contains the largest possible variance of the data. Each succeeding principal component accounts for the largest possible remaining variance while remaining orthogonal to all previous principal components.

Areas of known alteration were delineated when threshold values were exceeded in both the third and fourth principal components. This procedure also delineated other areas of potential surface alteration with spectral characteristics similar to the known altered areas. All areas of known and potential surface alteration were then digitally inserted into an image enhanced to show geomorphic variations for use in field checking.

Field checks of the images indicated that most digitally selected areas corresponded well to areas of surface alteration. All areas of previously known surface alteration were visible on the image except where the area was in shadow. In addition, previously unknown areas of alteration were indicated. The field checking suggested that an important characteristic of the targeted areas was the presence of iron staining, which is associated with the most common form of surface alteration on the Alaska Peninsula.

Limitations of note are (1) the surface alteration must be exposed, though some vegetation cover will not significantly affect selection of an area; (2) shadowed areas tend to be masked and therefore not selected; (3) the surface alteration must cover at least one acre to be recognized as a single picture element (pixel), though intensely altered areas that are smaller may be selected; and (4) not all areas of surface alteration are mineralized and not all mineralized areas have this type of surface alteration. However, these Landsatderived images are extremely useful in the resource assessment and the early stages of evalu- 
ation of an area. They allow rapid selection of areas that merit detailed field examination and geochemical sampling.

\section{MAHD ADH DHAHAB, A PROTEROZOIC EPITHERMAL PRECIOUS-METAL DEPOSIT, KINGDOM OF SAUDI ARABIA}

\section{R.G. Worl and J.L. Doebrich}

Mahd adh Dhahab is the largest of the many ancient gold mines scattered throughout the Precambrian Shield of Saudi Arabia and is the only one with recent production. More than 2 million ounces of gold has been produced from the northern of two known ore zones during ancient and recent times. The southern ore zone, which is about the same size as the northern ore zone, was discovered by the USGS, was developed by Gold Fields-Mahd adh Dhahab, and is being prepared for production by PETROMIN.

The two ore zones are in a north-trending zone of faults, altered rock, and metalliferous quartz veins and breccias approximately $1,200 \mathrm{ft}(360 \mathrm{~m})$ wide and $3,500 \mathrm{ft}(1,100 \mathrm{~m})$ long that cuts an eaststriking, north-dipping homoclinal sequence of volcanic, volcaniclastic, and epiclastic rocks of intermediate to felsic composition. Ore is localized where veins and breccias cut competent, coarsegrained, fragmental units directly below incompetent and impermeable fine-grained tuffaceous and fragmental units and near an epizonal rhyolite porphyry stock. Mineralization and alteration, except for early propylitization and silicification, is interpreted to have been caused by a single, large meteoric-water hydrothermal system, heated by the rhyolite, that was part of a larger, deeper magmatic-hydrothermal system.

Primary ore is composed of abundant chalcopyrite, sphalerite, pyrite, and less abundant complex precious-metal minerals. Gold and silver occur mainly as inclusions in chalcopyrite and sphalerite and as minute grains of telluride minerals disseminated in chlorite bands of banded quartz-chlorite-hematite veins. The most common telluride minerals are petzite, hessite, and sylvanite. Free gold is present but not abundant. Reconnaissance study of abundant, minute fluid inclusions in quartz veins showed them to contain both low-density, vapor-rich fluids and liquid-rich fluids. Primary fluid inclusions yielded homogenization temperatures of $110-238^{\circ} \mathrm{C}$. Preliminary isotopic analyses of sulfide minerals and quartz showed $\delta^{34} \mathrm{~S}$ values that range between 1.2 and 6.3 per mil, a typical range for hydrothermal sulfide minerals derived from an igneous sulfur source. The sulfur-isotope data and the ore mineral assemblages together suggest a large sulfide system (porphyry?) at depth. The $\delta^{18} O$ values of all stages of vein quartz throughout the area range between 8.5 and 11.1 per mil; these values indicate that the hydrothermal system consisted of dominantly meteoric water, which circulated in a single system uniform in temperature and $\delta^{18} \mathrm{O}$ content throughout the area during the entire period of mineralization.

Vein-related alteration, consisting of silicicsericitic-pyritic, chloritic, argillic, and silicic halos, was superimposed on broad zones of pervasive rhyolitic, silicic, potassic, and argillic alteration. Late pervasive propylitic alteration, superimposed on all alteration types, represents cooling and retrogression following contraction of the hydrothermal system.

Geochemical, biogeochemical, and geophysical anomalies delineate the known ore bodies and suggest the presence of more ore zones in the area.

\section{GENESIS OF METALLIFEROUS SEDIMENT IN THE ATLANTIS II DEEP, RED SEA}

\section{Robert A. Zierenberg}

Genetic models of many massive sulfide deposits postulate deposition of metalliferous sediment by venting of high-salinity hydrothermal fluids onto the sea floor. The Atlantis II Deep, Red Sea, is a currently active modern example of such a process. Areal extent of the brine pool in the Atlantis II Deep exerts primary control on the distribution of metalliferous sediment. The presence of a density-stratified brine allows dispersion of metal-rich brine to all parts of the deep. Currently, the brine vented in the Southwest Basin rises to the density interface between the brine pool and overlying seawater and then flows laterally along the interface. The lower brine mass is isolated from oxygenated seawater, allowing basemetal sulfides to precipitate in areas far from the site of venting. Oxide minerals precipitate at the interface.

The metalliferous sediments are composed primarily of intermixed and interlayered iron-rich 
clays, base-metal sulfides, and iron oxides, and less abundant sulfates and carbonates. The metalliferous sediments are extremely fine grained; interstitial water contents in the uppermost sediments are greater than 98 percent by weight. Sedimentation rates inside the brine pool are in excess of $100 \mathrm{~cm}$ per $1000 \mathrm{yr}$. High salinity, high temperature, and high trace-metal content of the brine produce a toxic environment, which ensures that the finely laminated sediments are not disturbed by bioturbation.

In contrast, metalliferous sediment deposited in the area of active brine venting is highly disturbed; soft-sediment deformation features are common. Heterolithic and homolithic breccias occur, some of which are metalliferous turbidites dislodged by tectonic activity from steep graben walls flanking the deep.

Influx of new brine causes further disruption, as well as deposition of epigenetic minerals in veins cutting unlithified metalliferous sediment. These veins provide a mineralogic record of the incoming hydrothermal fluid as it cools and mixes with interstitial brine. Smectites associated with the veins change from magnesium-rich saponites in the deepest veins to ferroan nontronites, which precipitate within the brine pool. Calculation of phase relations among smectite end members suggests that the change from magnesian saponite to ferroan nontronite results from cooling of the hydrothermal fluid. Temperatures calculated from oxygen isotopes in smectites range from 64 to $242^{\circ} \mathrm{C}$ and correlate with the $\mathrm{Fe} /(\mathrm{Fe}+\mathrm{Mg})$ ratio of the smectites, indicating that magnesium-rich smectite forms at higher temperature. Temperatures calculated from oxygen isotopes in coexisting anhydrite range from 184 to $264^{\circ} \mathrm{C}$. Anhydrite ${ }^{18} \mathrm{O}$ temperatures correlate well with smectite ${ }^{18} \mathrm{O}$ temperatures for the samples formed at higher temperature, but it appears that anhydrite ${ }^{18} \mathrm{O}$ does not maintain equilibrium as the hydrothermal fluid cools. Smectite ${ }^{18} \mathrm{O}$ values provide the best data for determining the temperature of the hydrothermal fluid venting into the Atlantis II Deep.

\section{MINERAL RESOURCE PROGRAMS}

The following section contains extended abstracts that briefly explain the various Mineral Resource Programs. A detailed explanation of each program is presented at a poster session. The programs have the following goals:

To assess the mineral resource potential of specific areas in the United States (particularly Federal lands) for resource management and Congressional action.

To provide timely assessments of the Nation's mineral resources. Such information is important for foreign and domestic policy decisions and for long-range planning related to mineral supply.

To identify new areas for exploration and develop new concepts of ore formation and distribution to increase our known mineral resources, particularly the strategic and critical minerals.

To improve current methodology and develop new techniques for identifying and evaluating mineral resources and analyzing resource data more efficiently and more precisely.

USGS mineral resource assessments are used in land-management decisions at all levels of government, from the Congress and the Executive Branch of the Federal Government to State and local governments. Resource and geoscience data generated through the programs provide basic information used for long-range planning for availability of nonfuel minerals on a national and international scale.

\section{AVAILABILITY AND APPLICATION OF NURE DATA SETS IN REGIONAL MINERAL SURVEY PROGRAMS OF THE U.S. GEOLOGICAL SURVEY}

\author{
Byron R. Berger, Thomas D. Fouch, \\ Richard H. Godson, and Bruce F. Molnia
}

Comprehensive mineral resource surveys of public lands by the USGS and associated Federal agencies require the assembly of large amounts of geological, geochemical, and geophysical information. Because most of the readily apparent metallic and nonmetallic mineral deposits at and near the surface have been found, the identification of new resources deeper beneath the surface requires both adequate amounts of regional data and sophisticated interpretation techniques. In its mineral resource surveys, the USGS draws on all available published and unpublished data that pertain to mineral occurrences. The geochemical and geophysical data sets collected under the National 
Uranium Resource Evaluation (NURE) program of the U.S. Department of Energy (DOE) are examples of publicly available information that is being used in USGS programs.

NURE data available from the USGS fall into six major categories: (1) geologic 1:250,000-scale quadrangle maps, (2) radiometric data from aerial surveys, (3) magnetic data from aerial surveys, (4) geochemical data from waters, rocks, and sediments, (5) radiometric data from borehole and NURE Drilling Program logging, and (6) evaluation data for resource estimates. These NURE data and related DOE publications are available in a variety of forms including map separates, openfile reports, and digital tapes. Digital geochemical and geophysical data are available from the USGS, EROS Data Center in Sioux Falls, South Dakota 57918. Publications and map separates are available from the USGS, Open-File Services Section, Western Distribution Branch, Denver, Colorado 80225 .

The NURE geochemical data are being used with multielement-association models based on analyses from the sampled mineralized and unmineralized rock exposures to investigate the regional geology and identify different mineral deposit types in western Montana. These interpretive products can serve as regional evaluations for land-management planning purposes, for exploration, and for assessing mineral potential and can help define geologic structure.

The NURE aeromagnetic data have been integrated with other airborne magnetic data to complete maps of large geographic areas such as the entire United States and the central midcontinent area. These serve to elucidate structures, define trends in the crystalline basement rocks, and outline intrusive masses.

A long-term comprehensive program is being formulated to examine the utility of the various types of NURE information in economic assessment of the Colorado Plateaus physiographic province. The relation of radiometric, magnetic, gravity, stream sediment, rock chemistry, and other NURE data to the region's known uranium deposits and geologic framework will be investigated. The Colorado Plateaus program of NURE data assessment and integration potentially involves study of NURE data generated under a variety of conditions and techniques in an area described by as many as 32 contiguous $1^{\circ} \times 2^{\circ}$ maps in five States. Uranium deposits in the region exist in a complex variety of geologic settings and were formed in several episodes of mineralization that range in age from late Paleozoic to Holocene. Results of these studies can be used to assess the utility of the various types of NURE data for assessment studies of other mineral deposits, to indicate new mineralized areas at the surface or in the subsurface, and to refine knowledge of the region's geologic framework.

\section{STRATEGIC AND CRITICAL MINERALS PROGRAM}

\section{Alfred H. Chidester}

The Strategic and Critical Minerals Program provides a continuing assessment of the Nation's endowment of strategic minerals and a continuing analysis of world mineral resources, for the formulation of national minerals policy and the identification of secure sources of minerals that are critical to the security, industrial production, and economic well-being of the country and that are vilnerable to disruptions in supply. The program has three principal components: (1) commodity resource information and analysis, which includes acquiring, managing, and analyzing commodity data, applying empirical and genetic mineral deposit models to the analysis of commodity data, and developing grade and tonnage models of mineral deposits; (2) regional resource information and analysis, which includes developing resource analysis methodologies; and (3) basic research in support of the program's commodity and regional resource information and analysis responsibilities.

Projects in support of the SCM Program are in the following categories:

Commodity resource, in which about 50 commodity geologists keep track of major activities and developments in mining, exploration, and technology for about 95 commodities.

Resource analysis methodology-research in techniques and methodologies for carrying out resource analysis.

International resource assessment, in which resource assessment specialists and commodity geologists cooperate with foreign counterparts in assessing the mineral resources of a developing country.

Metallogeny-studies of the relationship of mineral deposits to particular geologic terranes. 
Mineral deposits research-geologic research on the characteristics and genesis of selected strategic commodities, currently cobalt and tin.

Research support-research on a wide variety of geological, geophysical, geochemical, petrologic, mineralogic, and isotopic subjects in support of the overall Strategic and Critical Minerals Program.

Midcontinent program-a multidisciplinary study (geology, geochemistry, geophysics, geochronology, paleontology, isotope geology, and hydrogeology) of the Central United States, 10 degrees in latitude by 12 degrees in longitude, aimed at assessing the mineral resources of the buried Precambrian basement and the overlying sedimentary rocks.

Eastern Mesozoic basins-a multidisciplinary study of ten basins in the Eastern United States to develop deposit models for ore deposits in rift-basin and failed-rift environments, particularly for massive sulfides of the Noril'sk type.

Mineral resource data system (MRDS)-formerly known as Computerized Resource Information Base (CRIB), MRDS is a computer-based system designed to store, organize, and easily retrieve large amounts of mineral data. It has become a reference tool for Federal, State, and industrial scientists seeking descriptive information on mineral localities in the United States and in many foreign countries. All data in MRDS are organized into records that define individual mines, mineral occurrences, districts, or regions. Presently, there are about 72,000 records in the MRDS master file.

International Strategic Minerals Inventory (ISMI)-a cooperative program between the United States, Canada, West Germany, Australia, South Africa, and the United Kingdom, to compile and report geologic, reserve, production, and trade information on major deposits of selected commodities. Deposit records for manganese, chromium, nickel, and phosphate have been completed, and summary reports for manganese, chromium, and phosphate have been published. Compilation of deposit records for vanadium, cobalt, tungsten, titanium, graphite, and the platinum-group elements is now underway.

\section{THE DEVELOPMENT OF ASSESSMENT TECHNIQUES PROGRAM}

\author{
Charles G. Cunningham
}

The Development of Assessment Techniques (DAT) Program is a program of basic and applied research on the origin and the geological, geochemical, and geophysical expression of mineral deposit systems. The objectives are to develop concepts and techniques to improve the capability of identifying and evaluating mineral resources. To achieve these objectives, the program supports multidisciplinary field and laboratory studies directed toward understanding the processes by which mineral deposits form and developing new technology and models to assess the mineral resource potential in areas of concealed deposits.

The studies are organized under the following major categories:

Ore deposit models-Research that includes the acquisition and interpretation of fundamental geological, geochemical, and geophysical data to understand the processes by which deposits form and to identify the critical characteristics for their recognition. Syntheses of these data lead to empirical and genetic deposit models that improve the efficiency and effectiveness of resource assessments. This research includes multidisciplinary studies of disseminated gold and polymetallic sulfide deposits.

Geochemical exploration techniques-Field and laboratory studies of the processes and products of primary and secondary geochemical dispersion of trace and minor elements within and surrounding ore deposits. These studies include (1) research on regional hydrologic and mechanical transport of trace and minor elements and on computational techniques for data evaluation and interpretation; (2) detailed topical investigations of geologic, hydrologic, biologic, and atmogeochemical processes and the relationship of these processes to geochemical dispersion; and (3) research on analytical methods for resource assessment and ore deposit research. This category supports the multidisciplinary group studying the role of organic material in the formation and detection of ore deposits. 
Geophysical exploration techniques-Field and laboratory studies of the regional and detailed geophysical signatures of ore deposits. The studies include (1) research and development of new instrumentation, new analytical and computational methods, and a comprehensive set of computer programs for processing and interpreting gravity, magnetic, electrical, and electromagnetic data for evaluating ore deposits; (2) development and testing of remote-sensing techniques to discriminate geologic materials, to map altered rocks, and to detect structure, using thermal, multispectral, radar, and geobotanical data from satellite, aircraft, and ground measurements, for mineral resource assessment; and (3) study of petrophysical and spectral properties of minerals and rocks as an aid for identification of ore deposits in conjunction with other geophysical and remote-sensing techniques.

District and deposit studies-Multidisciplinary studies of mineralized areas at regional, district, and deposit scales. Establishment of geologic syntheses and research on critical factors controlling ore deposition.

Laboratory studies-Essential technical support for geological, geochemical, and geophysical research. Concepts and techniques developed or refined under this program are used in support of other programs including the AMRAP, CUSMAP, Mineral Resources of Public Lands, and Strategic and Critical Minerals Programs. This support function incorporates proven techniques and methodologies and provides a test ground for evaluating new technology for future use.

\section{THE CONTERMINOUS UNITED STATES MINERAL ASSESSMENT PROGRAM}

\section{Gary C. Curtin}

Regional assessments of the mineral and energy potential of the conterminous United States are being made under the Conterminous United States Mineral Assessment Program (CUSMAP). This program is providing up-to-date, systematic assessments of areas that have identified resources or are thought to have potential for mineral occurrences, especially strategic and critical minerals. Under CUSMAP, 1:250,000-scale quadrangles-areas of about $7,500 \mathrm{mi}^{2} \quad(20,000$ $\mathrm{km}^{2}$ )-are assessed for their mineral and energy potential by integrating existing information, reevaluating known mineral occurrences, and acquiring new data through coordinated geologic, geochemical, geophysical, and related studies. The results of the assessments are published in folio format tailored to meet the needs of existing and potential users, such as industry, the public, Congress, other Federal agencies, and State and local governments.

The primary goal of the program is to assess the mineral resource potential of 125 selected quadrangles during the next several decades. Priorities for selection of particular quadrangles have been based primarily on the known or perceived type and magnitude of their mineral potential. Priorities are also based on presence of areas, such as Forest Service and Bureau of Land Management lands, that are subject to both longterm planning and critical land-use decisions in the immediate future. Particular emphasis is placed on delineating areas that may contain concealed resources of known deposit types and on identifying environments for new types of deposits. Areas having potential for the occurrence of strategic and other mineral commodities such as cobalt, chromium, copper, gold, molybdenum, nickel, lead, lithium, tin, tungsten, zinc, and hydrocarbons have been identified and assessed during CUSMAP studies.

To date, assessments of nine quadrangles have been completed (fig. 1) and the maps and reports describing their mineral potential have been published, together with maps showing their geologic, geochemical, and geophysical characteristics. ${ }^{12}$ Fieldwork in an additional seven quadrangles has been completed, and the folio reports are in preparation. Fieldwork is underway in eight quadrangles. The program has proven valuable in providing (1) an appropriate and effective base for tying mineral occurrence and mining district data together on a regional basis, (2) a mineral data base for broader scale assessments in metallogenic provinces, and (3) a regional mineral resource framework for more detailed studies being made for Federal land-use and other critical policy decisions. Where appropriate, CUSMAP studies are

\footnotetext{
${ }^{12} \mathrm{~A}$ listing of reports prepared under CUSMAP is available from the office of Mineral Resources, U.S. Geological Survey, 913 National Center, Reston, VA 22092; phone (703) 860-6561.
} 


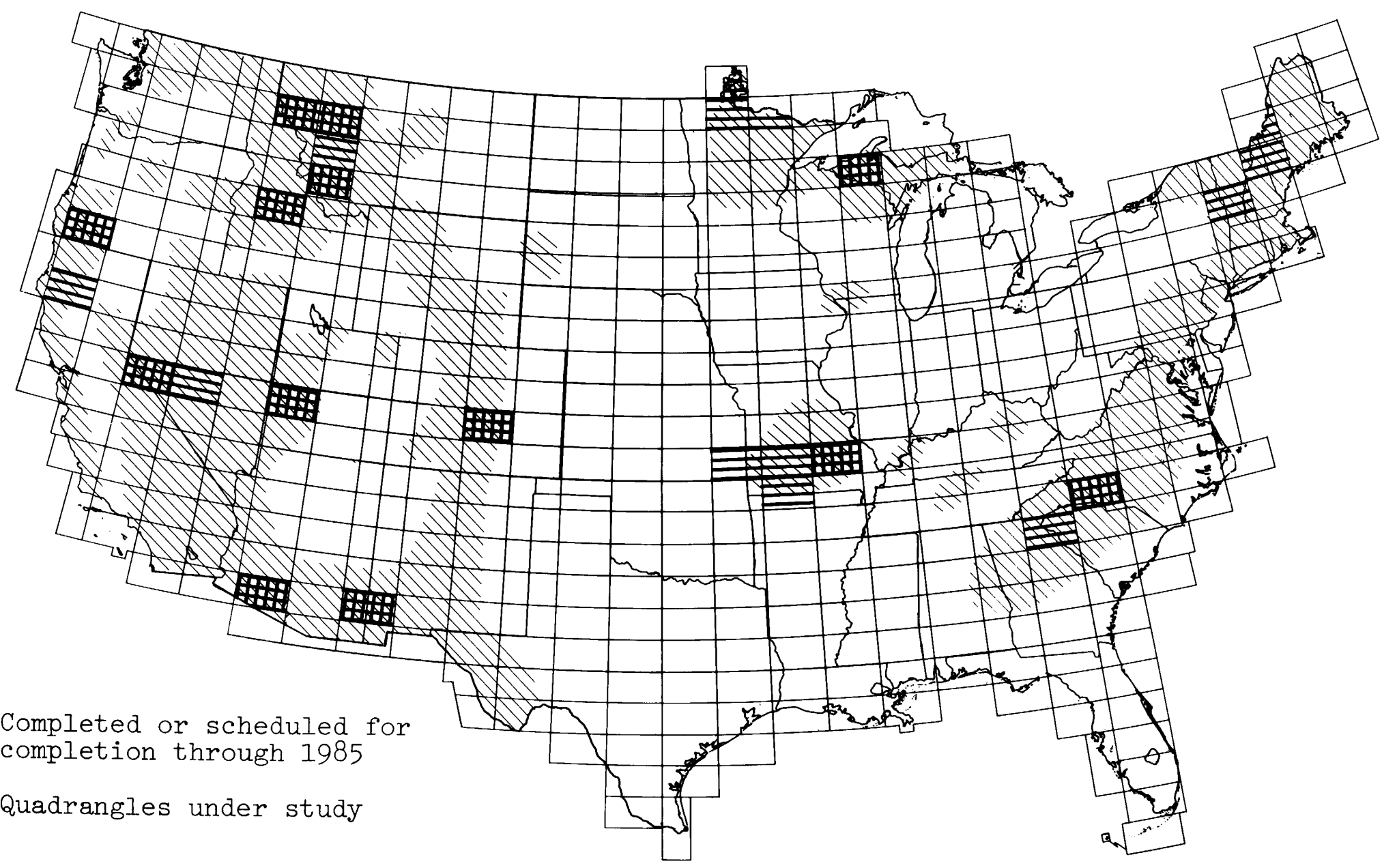

Mineralized areas

FIGURE 1.-Status of systematic mineral resource assessments of conterminous United States 1:250,000-scale quadrangles. 
closely coordinated with those of other USGS programs that deal with mineral resources, in order to provide the most effective data for furthering our knowledge of the Nation's mineral resources.

\section{URANIUM AND THORIUM INVESTIGATIONS IN THE U.S. GEOLOGICAL SURVEY}

\section{Thomas D. Fouch and Jennie L. Ridgley}

In 1984, the full responsibility for the geologic resources studies of uranium and thorium deposits was passed from the U.S. Department of Energy (DOE) to the USGS. The transfer of that responsibility has somewhat altered the USGS basic science program of uranium and thorium investigations to reflect the Survey's requirement to respond to the Nation's need for basic information on uranium and thorium geology and resources. As a result, the current goals of the USGS Uranium and Thorium research program are (1) to improve the understanding of the geologic habitat and distribution of identified domestic resources of uranium and thorium, (2) to apply this understanding to the development of regional guides to assess the undiscovered resources, and (3) to develop techniques for increasing the discovery rate and exploitation of economically recoverable nuclear raw materials. Attainment of these goals permits the USGS to advance the basic science of uranium and thorium geology, to provide information on undiscovered uranium and thorium endowment to the Energy Information Administration (EIA) of the DOE, and to assess the validity and utility of data sets and samples collected under the DOE's National Uranium Resource Evaluation (NURE) program.

The Uranium and Thorium program concentrates much of its effort on topics or geographic areas where study results can be expected to affect estimates of undiscovered uranium and thorium endowment most significantly. Four major geographic and topical areas for new emphasis have been identified, and program resources are being focused in these areas. They are (1) surficial uranium deposits (SUDS) throughout the United States, (2) uranium in sedimentary breccia pipes of the southern Colorado Plateaus, (3) uranium in metamorphic rocks of the Piedmont physiographic province of the Eastern United States, and (4) uranium in sedimentary rocks of the northern Great Plains. These and other program geologic research studies that are continuing in sedimentary, igneous, and metamorphic rocks in various parts of the United States will produce topical scientific products in the fields of radiogenic and stable isotopes, paleogroundwater movement, water-water and rock-water reactions, geochemical redox systems, and organic geochemical-metal deposit relations.

The SUDS project has been examining uraniferous organic-matter-rich sediments in surficial environments in several Western, Rocky Mountain, and Northeastern States. These uraniferous sediments commonly are developed in mountain terrain underlain by granitic rocks. A Holocene boggy meadow in Washington State is currently being mined for uranium. Other surficial deposits of the Southwest United States and southwestern Great Plains are associated with caliche formation.

In northern Arizona, Paleozoic formations contain breccia pipes filled with blocks of country rock (sandstone, shale, and limestone). Some pipes are mineralized with uranium, copper, cobalt, and precious metals. Mineralized pipes in the region contain small but rich uranium ore bodies, some of which are now the focus of mining activity.

In Virginia, altered Paleozoic metamorphic rocks of the Piedmont province are locally rich in uranium minerals. Similar occurrences may exist elsewhere in the province where tectonic and mineralizing events seem comparable.

USGS Uranium and Thorium program efforts, begun before 1984, will continue in the San Juan and other Rocky Mountain basins, in the Lake City caldera region of southwest Colorado, and through topical studies of world-class uranium deposits.

\section{MINERAL RESOURCES OF PUBLIC LANDS}

\section{Gus H. Goudarzi and Susan M. Marcus}

The objectives of the Mineral Resources of Public Lands Program are to conduct mineral surveys to assess the mineral resource potential of those Forest Service lands that are included or are proposed for inclusion in the National Wilderness Preservation System and of those lands administered by the Bureau of Land Management for which a preliminary determination of wilderness suitability has been made (fig. 2). A mineral survey involves coordinated geologic, geochemical, and 
FOREST SERVICE NEEDS

Wilderness type study - PL. 88-577 - 1:50,000 scale

Statutory requirements 1965-1984- PL. 88-577 - 1:50,000 scale

RPA. -PL. 93-378, 1974 NFMA. PL. $-94-588,1978-1: 250,000$ scale

About 220 million acres - 155 National Forests

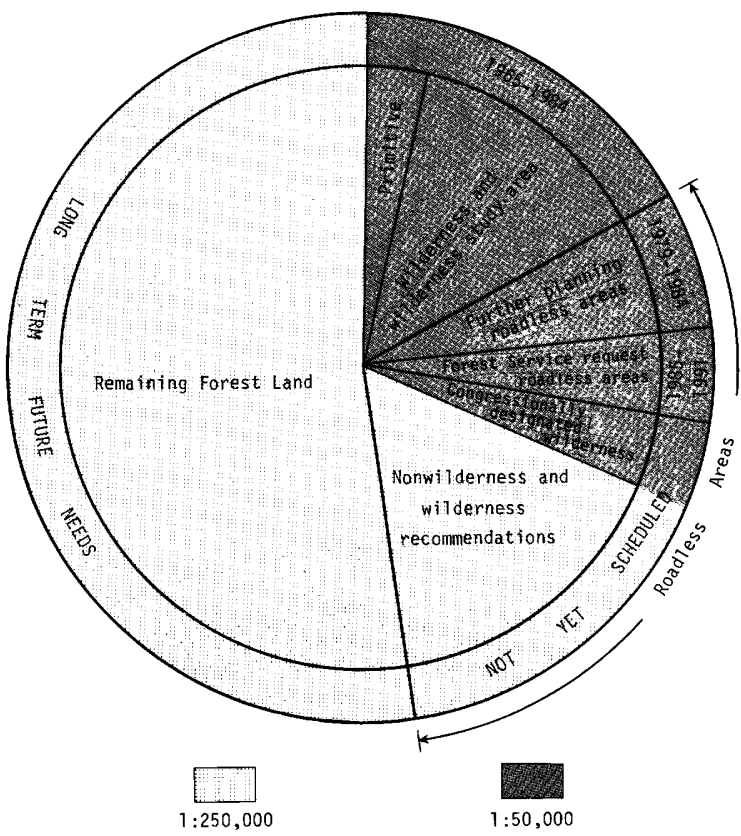

BUREAU OF LAND MANAGEMENT NEEDS

Wilderness type study PL. 88-577

Federal Land Policy and

Management Act (FLPMA)

23.2 million acres - judged preliminarity

suitable for wilderness

ISA - Instant Study Areas

CDCA - California Desert Conservation Areas

WSA - Wilderness Study Areas

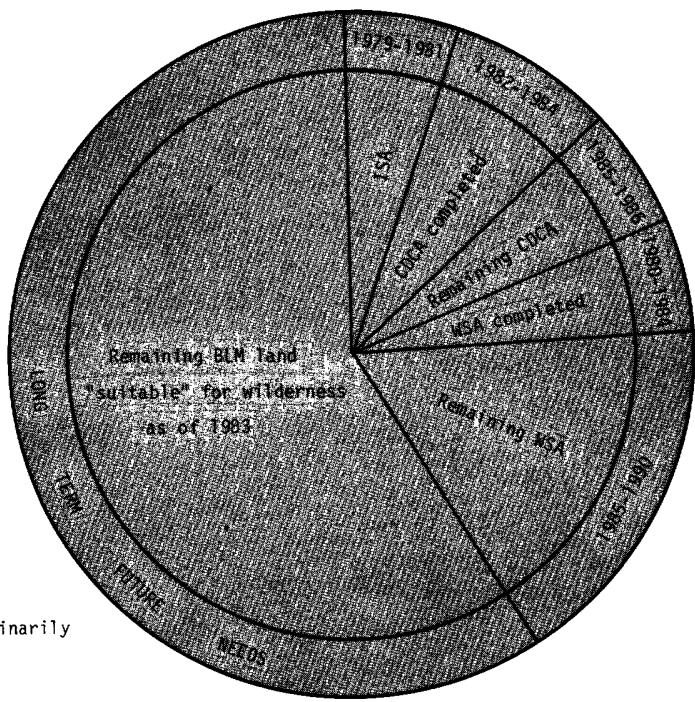

$1: 50,000$

FigURE 2.-U.S. Geological Survey Wilderness Mineral Surveys on lands managed by the Forest Service and the Bureau of Land Management. RPA, Forest and Rangeland Renewable Resources Planning Act of 1974; NFMA, National Forest Management Act of 1976. 
geophysical studies, which provide data for estimating identified resources and the potential for the occurrence of undiscovered mineral resources in a designated area. Mineral resources of public lands are usually assessed through applying occurrence models to the geologic terranes of those lands.

Principal products of a wilderness mineral survey are a mineral resource report and a mineral resource potential map at a scale that ranges from $1: 24,000$ to $1: 250,000$, depending on the size of the area. The data and interpretations used in the assessment of the mineral resource potential are published as Miscellaneous Field Studies (MF) maps, including geologic, geochemical, and geophysical maps, or as open-file reports. Where appropriate, a mines and prospect map is also prepared.

Through this program, geologic maps at appropriate scales delineate rock units and structures that control known or potential mineral and energy resources. Geochemical surveys determine patterns of anomalous metal values indicative of concealed mineral deposits. Geophysical studies determine regional variations in magnetic, gravity, and electrical fields to identify geologic environments favorable for the occurrence of concealed mineral deposits.

The recently published two-volume U.S. Geological Survey Professional Paper 1300 summarizes and presents the results of twenty years of mineral surveys on about $\mathbf{4 5}$ million acres of public lands, chiefly in the National Forests, in a form that decisionmakers will be able to use effectively in balancing wilderness preservation against mineral resource availability. These studies were made under the provisions of the Wilderness Act of 1964, Public Law 88-577.

U.S. Geological Survey Circular 901 describes the joint mineral surveys conducted by the USGS and U.S. Bureau of Mines of those public lands preliminarily recommended by the Bureau of Land Management as suitable for inclusion in the $\mathrm{Na}$ tional Wilderness Preservation System. These studies are made under the provisions of the Federal Land Policy and Management Act of 1976, Public Law 94-579. Thus far, studies have been completed on more than 3 million acres; about 10 million acres remain to be studied by 1991.

\section{References Cited}

Marsh, S.P., Kropschot, S.J., and Dickinson, R.J., eds., 1984, Wilderness mineral potential: U.S. Geological Survey Professional Paper 1300, 1183 p.

Beikman, H.M., Hinkle, M.E., Frieders, Twila, Marcus, S.M., and Edwards, J.R., 1983, Mineral surveys by the Geological Survey and the Bureau of Mines of Bureau of Land Management Wilderness Study Areas: U.S. Geological Survey Circular 901, 28 p.

\section{FEDERAL MINERAL LAND INFORMATION SYSTEM}

\section{Richard L. Kleckner}

The U.S. Geological Survey is developing the Federal Mineral Land Information System (FMLIS), which will allow land managers, policymakers, and others to rapidly retrieve, display, and analyze minerals information on Federal lands at regional, State, and National levels. This capability is being developed in order to input, manipulate, analyze, and output digital data through a geographic information system (GIS). A GIS is a tool for integrating and analyzing spatial data. Functions within a GIS allow for changes in map scale and projection; data editing; registration and overlay; selection, retrieval, and display of data; tabulation of acreages; and measurement of distances. In an interactive environment, the user can rapidly analyze data, examine alternatives, and test hypotheses.

The types of data to be analyzed in the Federal Mineral Land Information System include Federal surface ownership; subsurface mineral rights; restrictions to mineral development; identified mineral occurrences, mines, and deposits; and designations of mineral potential. Base cartographic data such as political boundaries, public land survey system, transportation, and hydrography provide a basis for locating and relating the FMLIS data.

To move from a concept to an operational system requires research on data sources, data capture, GIS development, system maintenance, and coordination. Through 1985 , the primary emphasis will be on developing the utility of the system and its ability to retrieve, display, and analyze minerals information on Federal lands. 
Specifically, the objectives of FMLIS are to (1) develop a GIS containing information on surface ownership, subsurface mineral rights, restrictions to mineral development, mineral occurrences, and designations of mineral potential for Federally owned or managed land, (2) develop procedures for accessing and analyzing data in the GIS in line with agency requirements, (3) establish agreements with appropriate Federal agencies for inputting and maintaining data in the GIS, and (4) implement procedures for an operational system by FY 1986.

\section{THE U.S. GEOLOGICAL SURVEY EEZ PROGRAM}

\section{Terry W. Offield}

The Exclusive Economic Zone (EEZ) proclaimed by President Reagan in 1983 enlarges the Nation's offshore domain to about 3 billion acres. Extending to 200 nautical miles, much of this area is literally frontier, containing vast areas of Continental Shelf, Slope, and Rise and deep sea floor about which only the most rudimentary information exists. The EEZ is believed to have major energy and mineral resource potential. Estimates are that about one-third of the oil and gas yet to be discovered in the United States will be found in offshore areas. Potentially economic deposits include massive sulfide deposits found in ocean spreading centers, cobalt-rich manganese crusts on seamount surfaces, nearshore heavy-mineral placers, phosphorite, and sand and gravel.

The USGS marine-geology program is designed to acquire the information on geologic settings and history, geologic processes past and present, and resource occurrence or potential that will be needed for a national effort to explore and develop the EEZ. A first, major step, which will require many years, is the preparation of maps of the sea floor. Sidescan sonar image mosaics that already have been produced in preliminary form cover the conterminous Pacific EEZ from the edge of the shelf to 200 nautical miles. The images show the sea floor at $60-100 \mathrm{~m}$. More than 100 new volcanos have been found, some as large and freshappearing as Mount St. Helens; the Juan de Fuca and Gorda spreading centers are seen in their entirety, along with the fracture zones that terminate them; major river courses meander down the slope and across the deep sea floor for hun- dreds of kilometers; ripple-like large-scale bedforms have been seen at water depths of more than $3,500 \mathrm{~m}$; and large subsea landslides have been delineated. Similar reconnaissance imaging of the EEZ around the continent will be done over the next few years, to be followed by surveys of the Hawaiian region and the EEZ around U.S.-related Pacific islands. Bathymetric mapping is underway through a cooperative agreement with the $\mathrm{Na}$ tional Oceanic and Atmospheric Administration.

Geophysical surveying and geologic mapping continue and will expand to cover the slope and rise and deep sea floor. Existing geophysical and geologic data will be compiled and interpreted. Other studies address the geologic processes that produced the rocks and their settings. Observations include sampling from shallow and deep drill holes as available, patterns of sedimentation and erosion both in modern environments and in the rock record, chemistry and petrology of the rocks of the seabed and below, comparison of rocks and structures in similar settings offshore and on land, and organic geochemical character of rocks and their environments to appraise the thermal maturation histories. Studies also focus on the geology and processes of resource formation and occurrence. Manganese crust samples from oceanographic institution archives are being collected and analyzed for cobalt, nickel, and trace elements; new surveys will probe the occurrence and origin of such crusts on mid-Pacific seamounts. Other studies focus on the geology of ocean spreading centers and the massive sulfide deposits that occur in such areas of interaction of seawater and new basaltic crust. These studies address questions of chemical and mineralogical differences between areas, processes of mineralization, comparison with ancient onshore deposits believed to be of similar origin, and resource potential.

\section{THE ALASKA MINERAL RESOURCES ASSESSMENT PROGRAM}

\section{Gary R. Winkler}

AMRAP (Alaska Mineral Resources Assessment Program), the prototypic U.S. Geological Survey regional resource assessment program, enters its second decade with the continuing goal to provide comprehensive information on the mineral and energy resource endowment of Alaska to 


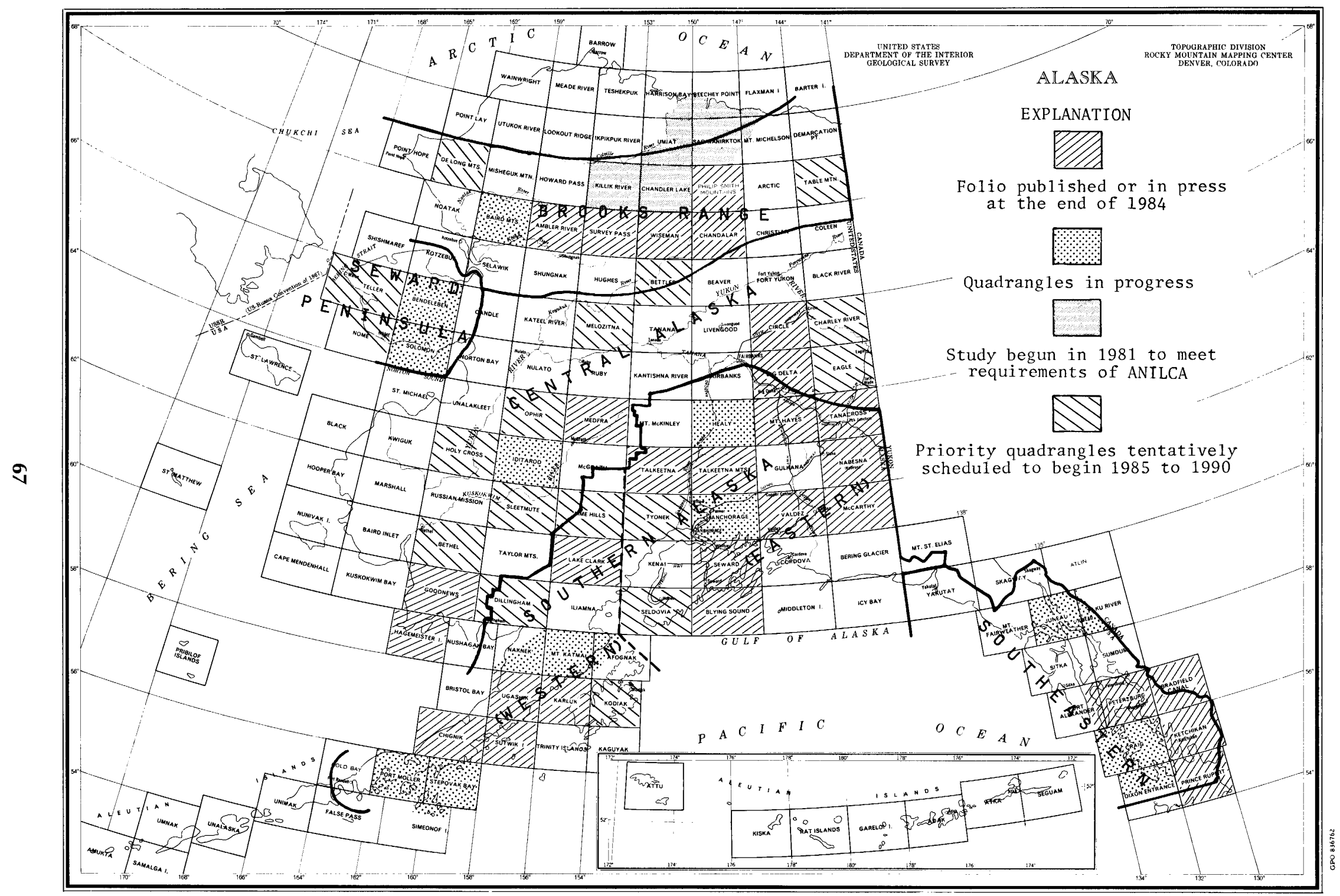

FIGURE 3.-Status of the Alaska Mineral Resources Assessment Program (AMRAP), February 1985, showing 1:250,000 quadrangles completed, in progress, or scheduled for study in the next five years. Regions of the State that are covered by summary mineral resource folios at scales of 1:600,000 to 1:1,000,000 are outlined by bold lines. 
the public, the private sector, the academic community, and those who are concerned with national mineral policy. The program is designed (1) to provide information to land management agencies for decisions regarding the classification and allocation of Alaska's Federal lands in response to mandates of the Alaska National Interest Lands Conservation Act (ANILCA); (2) to produce systematic, state-of-the-art geoscience information to the mineral and energy industries, Alaska natives, and other public and private interests concerned with exploration and development of Alaska's resources; and (3) to expand the general knowledge of Alaska's complex geological setting, much of which is known presently only in reconnaissance.

In order to meet these broad objectives, AMRAP conducts four levels of study at progressively greater detail: Level 1, statewide compilations to identify the total mineral and energy resource base available for national needs; Level 2, synoptic regional assessments of geologic provinces (scale, 1:1,000,000), with an analysis of probable sizes and grades of potential resources (fig. 3); Level 3, interdisciplinary studies of key 1:250,000-scale quadrangles that are thought to have significant mineral or energy potential (fig. 3 ; and Level 4, investigations of mineral districts and deposits, energy provinces, and technical topics that will aid in interpreting the setting and character of specific mineral or energy resources in Alaska.

The core of the program presently is Level 3 studies. Fieldwork has been completed in 33 quadrangles, and complete folios (which include geologic, geochemical, and geophysical maps, a mineral and energy resource assessment, a summary circular, and derivative reports) are available for 19 of those quadrangles. Many individual folio components are available presently for the other 14 , and investigations continue in 16 quadrangles.
About 40 percent of the quadrangles intended for completion in the program are completed or are being studied. When key quadrangles in a large region or geological province have been completed (for example, the Seward Peninsula), a Level 2 synthesis is begun or updated. A regional mineral resource assessment for southeastern Alaska has been completed recently that has drawn upon new detailed Level 3 studies. A similar stage will be reached soon for the Alaska Peninsula, the Brooks Range, and the eastern part of southern Alaska (fig. 3). Synoptic mineral and energy resource assessments will provide up-to-date information on the potential for these regions and will show where additional information is needed.

Level 4 research investigations always have been an integral part of AMRAP. These studies include a broad spectrum of topical or detailed geological mapping, geochemical and isotopic studies, chronostratigraphic and biostratigraphic interpretation, geophysical studies, and evaluation of specific mineral or energy resource occurrences or commodities. Work currently underway on 40 projects will improve mineral deposit models, appraise specific resource potentials, and provide data that can directly aid exploration and development.

Two approaches in Level 4 studies will be accelerated in the next few years. First, detailed and comprehensive occurrence studies have begun of large, high-grade districts, such as the Red Dog and affiliated deposits in the western Brooks Range, and districts that have unique features, such as the southern Ambler district in the southwestern Brooks Range, where the copperbase-metal deposits are rich in cobalt. Secondly, detailed multidisciplinary studies of strategic commodities, such as tin and chromium, have begun because knowledge of Alaska's large apparent resources will be important in the future. 


\section{ORGANIZATION OF THE U.S. GEOLOGICAL SURVEY}

Office

Name

Telephone

City

\section{Office of the Director}

Director

Associate Director

Assistant Director for Research

Assistant Director for Engineering Geology

Assistant Director for Administration

Assistant Director for Programs

Assistant Director for Intergovernmental Affairs

Chief, Public Affairs Office

Assistant Director for Information Systems

\section{National Mapping Division}

Chief

Dallas L. Peck

Doyle G. Frederick

Bruce B. Hanshaw

James F. Devine

Edmund J. Grant

Peter F. Bermel

John J. Dragonetti

Donovan B. Kelly

James E. Biesecker

Rupert B. Southard

Robert M. Hamilton

Philip Cohen
$703 / 860-7411$

$703 / 860-7412$

$703 / 860-7488$

$703 / 860-7491$

$703 / 860-7201$

703/860-7435

$703 / 860-7414$

$703 / 860-7444$

703/860-7108

$703 / 860-6231$

$703 / 860-6531$

703/860-6921
Reston

Reston

Reston

Reston

Reston

Reston

Reston

Reston

Reston

Reston

Reston

Reston

Chief Hydrologist

\section{ORGANIZATION OF THE GEOLOGIC DIVISION}

\section{Office of the Chief Geologist}

Chief Geologist

Associate Chief Geologist

Assistant Chief Geologist for Program

Assistant Chief Geologist, Eastern Region

Assistant Chief Geologist, Central Region

Assistant Chief Geologist, Western Region

\section{Office of Mineral Resources}

Chief

Chief, Branch of Alaskan Geology

Chief, Branch of Eastern Mineral Resources

Chief, Branch of Central Mineral Resources

Chief, Branch of Western Mineral Resources

Chief, Branch of Exploration Geochemistry

Chief, Branch of Resource Analysis

Chief, Branch of Analytical Chemistry

Chief, Branch of Geophysics

\section{Office of Energy and Marine Geology}

Chief

Chief, Branch of Oil and Gas Resources

Chief, Branch of Coal Resources

Chief, Branch of Energy Minerals

Chief, Branch of Pacific Marine Geology

Chief, Branch of Atlantic Marine Geology
Robert M. Hamilton

William C. Prinz

Benjamin A. Morgan

Bruce R. Doe

Harry A. Tourtelot

Carroll Ann Hodges

Glenn H. Allcott

Thomas P. Miller

Bruce R. Lipin

Charles H. Thorman

Edwin H. McKee

Byron R. Berger

Lawrence J. Drew

Philip A. Baedecker

Frank C. Frischknecht

Terry W. Offield

Dudley D. Rice

Robert L. Rioux (Acting)

Thomas D. Fouch

David G. Howell

William P. Dillon
703/860-6431

703/860-6531

$703 / 860-6532$

703/860-6584

$703 / 860-6631$

303/236-5438

415/323-8111

703/860-6561

907/786-7403

703/860-6913

$303 / 236-5568$

415/323-8111

$303 / 236-1800$

703/860-6446

$703 / 860-7246$

303/236-1204

$303 / 236-5711$

703/860-7734

$303 / 236-1644$

415/323-8111

$617 / 548-8700$
Reston

Reston

Reston

Reston

Denver

Menlo Park

Reston

Anchorage

Reston

Denver

Menlo Park

Denver

Reston

Reston

Denver

Reston
Denver
Reston
Denver
Menlo Park
Woods Hole


Office of Regional Geology

Chief

Chief, Branch of Eastern Regional Geology

Chief, Branch of Central Regional Geology

Chief, Branch of Western Regional Geology

Chief, Branch of Isotope Geology

Chief, Branch of Astrogeology

Chief, Branch of Paleontology and Stratigraphy
Eugene H. Roseboom

Gregory S. Gohn

Robert B. Raup

Desiree E. Stuart- Alexander

Robert E. Zartman

Gerald G. Schaber

Richard Z. Poore
A. Thomas Ovenshine
John M. Aaron

Albert M. Rogers

Wayne R. Thatcher

L.J. Patrick Muffler

Office of Scientific Publications

Chief

Office of International Geology

Chief

\section{Addresses}

U.S. Geological Survey

Reston, VA 22092

U.S. Geological Survey

Branch of Alaskan Geology

4200 University Drive

Anchorage, AK 99508-4667
U.S. Geological Survey

Box 25046

Denver Federal Center

Denver, CO 80225

U.S. Geological Survey 2255 North Gemini Drive Flagstaff, AZ 86001
$703 / 860-6411$

$703 / 860-6404$

$303 / 236-1259$

$415 / 323-8111$

$303 / 236-7880$

602/527-7015

$703 / 860-7289$

$703 / 860-6471$

$415 / 323-8111$

$303 / 236-1510$

415/323-8111

303/236-1585

415/323-8111

$415 / 323-8111$

$703 / 860-6575$

Reston

Reston

Reston

Denver

Menlo Park

Denver

Flagstaff

Reston

Reston

Menlo Park

Denver

Menlo Park

Denver

Menlo Park

Menlo Park

$703 / 860-6418$

Reston

U.S. Geological Survey 345 Middlefield Road Menlo Park, CA 94025

U.S. Geological Survey Quissett Campus, Building B Woods Hole, MA 02543 


\section{INDEX OF AUTHORS}

Armstrong, Augustus K. --

Bagby, W.C. --

Barton, Paul -_- 30

Bawiec, W.J. --_- 40

Berger, Byron R. -_- 58

Bischoff, James L. ---_---_---_-_-_-_-_---- 27

Blakely, R.J. --_-_-_-_-_-_ 40

Bodnar, Robert J. --_-_-_-_- 1

Botbol, Joseph M. ---_---_-_-_--- 16

Bove, D.J. ---

Briskey, Joseph A. -----_-_-_-_-_------- 3

Campbell, David L. --_-_-_-_-_-_-_-_----- 3

Cannon, William F. --.--- 4

Case, J.E. ----------

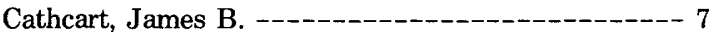

Chao, T.T. --_- 29

Chidester, Alfred H. --_-_-_- 59

Chou, I-Ming -------- 1

Clague, David A. --_--

Cole, George P. - -

Collins, William E. --_-_-_-- 43

Connelly, Thomas J. ------

Conway, Clay M. --

Cox, D.P. - - 52

Cunningham, Charles G. ---_--_-- 3,33,60

Curtin, Gary C. -- 61

Czamanske, G.K. --

Dersch, John S. ---_-_- 53

Desborough, George A. --_-- 43

DeYoung, Jr., John H. --_-_-_-- 32

Dingess, Paul R. --_--_-- 3

Doebrich, J.L. - - 57

Drew, L.J. ---_-_-_- 40

du Bray, Edward A. --_-_-_-_-_-_-_-_---- 9

Duval, Joseph S. --_-- 3

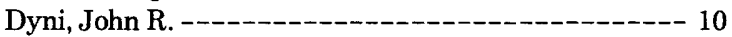

Elliott, Sarah S. --_---_- 55

Erdman, J.A. --

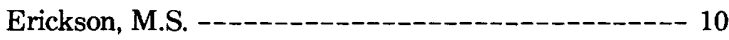

Erickson, R.L. --_- 10

Escowitz, Edward C. --_-_-_-_-_-_-_-_-_-_---16

Flanigan, Vincent J. ---_-_-_-_-_-_---11

Foose, Michael P. -

Force, Eric R. ---_-_- 4

Fouch, Thomas D. --_-_- 58,63

Fournier, Robert O. --_---_-_-_-_-- 13

Gair, Jacob E. --_---_-- 14

Gaylord, Walt B. ---_---_-_- 3

Gilbert, Raymond C. --------_--- 3

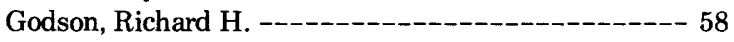

Goldfarb, R.J. ---_-_-- 1

Gottfried, David --_-_- 46

Goudarzi, Gus H. ---_--_-- 63

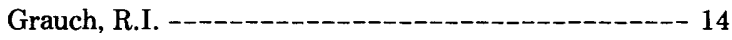

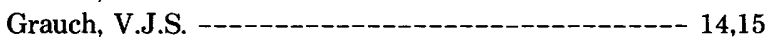

Grosz, Andrew E. - - 16

Grybeck, Donald J. - - 17

Haas, Jr., John L. --
Hall, Robert B. ----_--- 24

Hall, Wayne --_-_-- 19

Hatch, Joseph R. --_-_-_-_-_-_ 20

Hatcher, Patrick G. --_--_-_-_ 21,39

Hathaway, John C. --_--_--_-_-_-_-_---- 16

Hearn, Jr., B. Carter ---------- 22

Hein, James R. --- 23

Helz, R.L. ---

Hemingway, Bruce S. --- 45

Heyl, Allen V. ------_-- 20,24

Hinkle, Margaret E. --_---_-_-_---- 25

Hofstra, Albert H. --_--_-_-_-_-_-_-_---- 28

Holmes, Mark --_--_-- 8

Hon, Ken --

Horton, Robert ---_-_-_-_-_-_-_-_-_------ 26

Jones, O.D. -----_--_-_-- 43

King, J. David ----_-_-_-_-_-- 20

Kleckner, Richard L. ---- 65

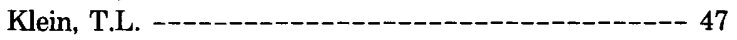

Kleinkopf, M.D. --_- 40

Koski, Randolph A. -----

Koslow, M.H. -------------

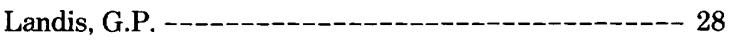

Lange, Ian M. ----_-_-_-_-_-_- 36

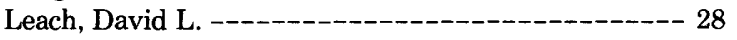

Learned, Robert E. ------------ 29

Leonard, B.F. --

Lipin, Bruce R. --_-_-_ 40

Loferski, Patricia J. - - 40

Long, Carl L. ---

Lopez, Ricardo ---------- 16

Ludington, Steve --_-_ 19,30

Luedke, Robert G. ---_-_-_-_-_-_-- 31

Madden, Dawn J. ------_-_-_-_-_--- 49

Manheim, Frank T. --_-_- 23

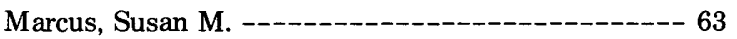

McCammon, Richard B. ---_--_---_---_----- 32

McCarthy, J. Howard --_-_-_-_-_---- 25

McGee, Elaine S. ---_-_-_-_-_-_-- 22

McGee, Linda G. --_-_-_-_-_ 44

McKown, D.M. ------- 30

Medlin, Antoinette L. -- 32

Molnia, Bruce F. ---_-_- 58

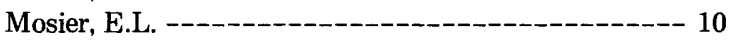

Naeser, C.W. ----_-- 3,33

Nelson, Steven W. -

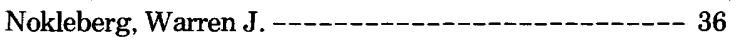

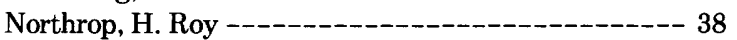

Offield, Terry W. --_-_-_-_-- 66

Orem, William H. ----_--_-_-- 39

Owens, James P. -_-_- 39

Page, Norman J --_-_-_-_-_ 19,40

Parduhn, Nancy L. --_-_-_-_-_-_-_------ 42,55

Pickthorn, W.J. ---

Pitkin, James A. --

Podwysocki, M.H. --_-_- 43

Poole, Forrest G. - 43

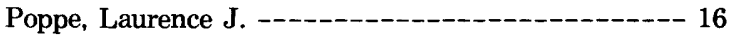


Power, M.S.

43

Raines, Gary L.

44

Reynolds, R.L.

$-14$

Ridgley, Jennie L.

63

Robie, Richard A. --_-_-_-_-_- 45

Robinson, Jr., Gilpin R. --_-_-_- 46

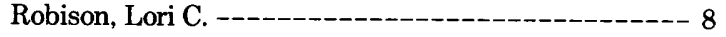

Roedder, Edwin --_-_-_-_-_-_-_-_- 1

Rytuba, James J. --_-_-_-_-_-_-_-_-_-_- 47

Sanzolone, Richard F. --_-_- 29

Schmidt, R.G. --

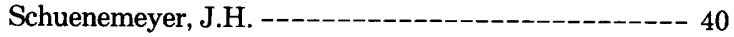

Shawe, Daniel R. --_-_-_-_-_- 48

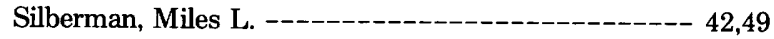

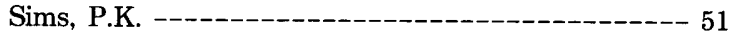

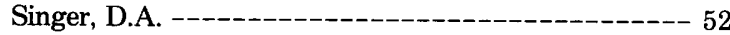

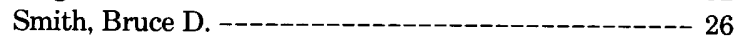

Smith, Robert L. --_-_-_-_-_- 52
Spiker, Elliott C. ---_-_-1--0- 39

Steven, Thomas A. --_-_-_-_- 3

Sutley, Steven J. --_-- 44

Sutphin, David M. -------------- 32

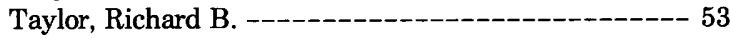

Theodore, Ted G. --_--_-_-_-_-_-_-_-_-_-_---- 19

Updegraff, David M. --------_-_-----_--------- 55

USGS Juan de Fuca Study Group --_-_-_-_------ 54

Viets, J.G. --

Watterson, John R. --_-_-_-_-_-_---- 42,55

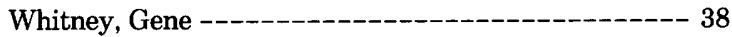

Williams, S. Jeffress -------- 16

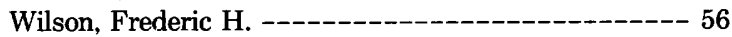

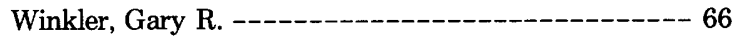

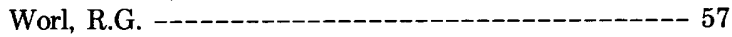

York, James E. ---_-_-_-_-_-_-_-_-_-------- 56

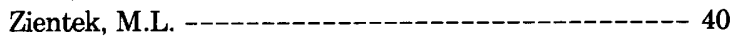

Zierenberg, Robert A. --_-_-_, 27,57 